U.S. Geological Survey Groundwater Resources Program

\title{
Comparison of Groundwater-Model Construction Methods, Representations of Glacial Geology, Model Designs, and Groundwater-Model Flow Simulations within Elkhart County, Indiana
}
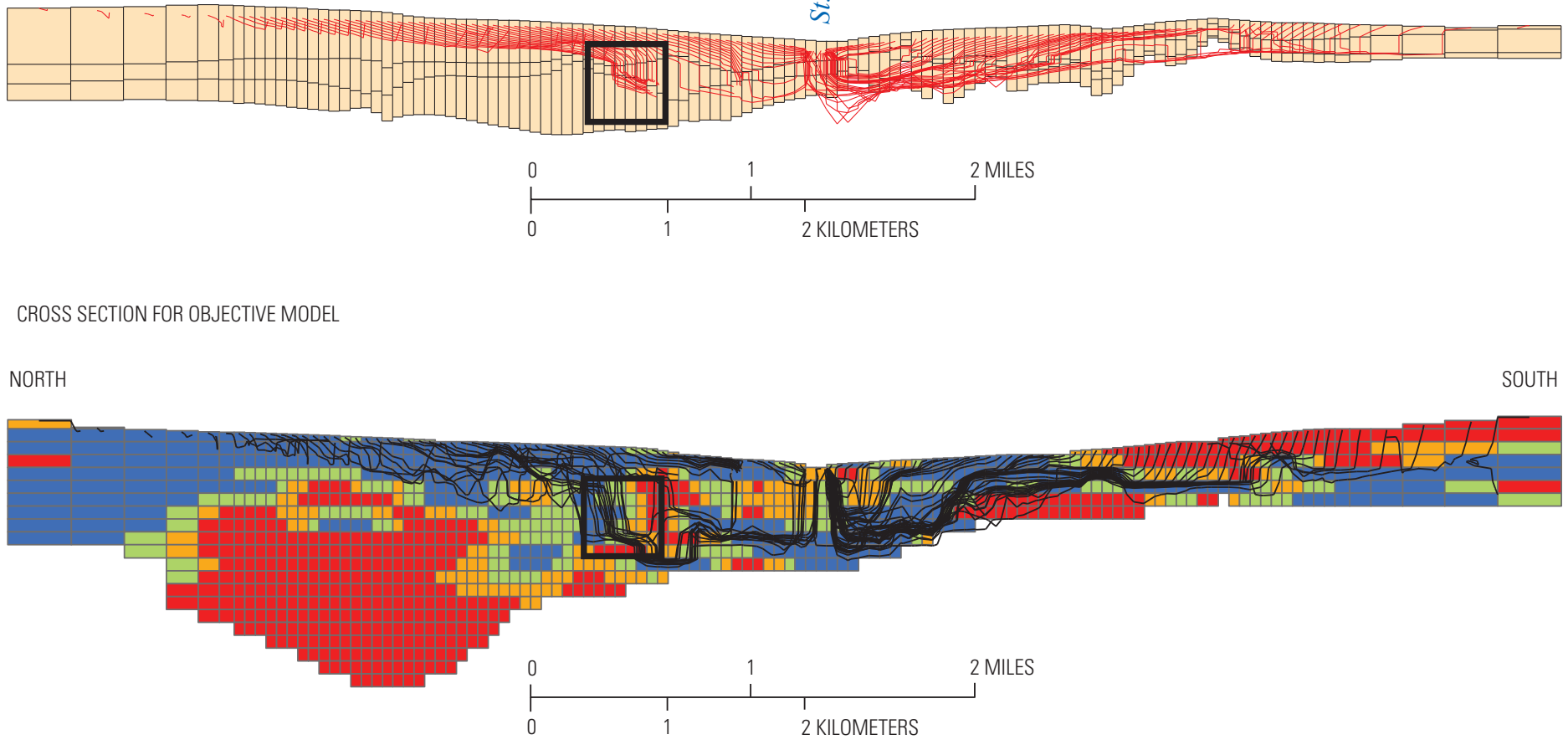

Scientific Investigations Report 2019-5088 
Cover. Cross-sectional flow diagram along column 29 for the subjective model and the objective model, taken from figure 22 of this report. 


\section{Comparison of Groundwater-Model Construction Methods, Representations of Glacial Geology, Model Designs, and Groundwater-Model Flow Simulations within Elkhart County, Indiana}

By Leslie D. Arihood, David C. Lampe, E. Randall Bayless, and Steven E. Brown

U.S. Geological Survey Groundwater Resources Program

Scientific Investigations Report 2019-5088 


\title{
U.S. Department of the Interior DAVID BERNHARDT, Secretary
}

\author{
U.S. Geological Survey \\ James F. Reilly II, Director
}

U.S. Geological Survey, Reston, Virginia: 2019

For more information on the USGS - the Federal source for science about the Earth, its natural and living resources, natural hazards, and the environment-visit https://www.usgs.gov or call 1-888-ASK-USGS.

For an overview of USGS information products, including maps, imagery, and publications, visit https://store.usgs.gov.

Any use of trade, firm, or product names is for descriptive purposes only and does not imply endorsement by the U.S. Government.

Although this information product, for the most part, is in the public domain, it also may contain copyrighted materials as noted in the text. Permission to reproduce copyrighted items must be secured from the copyright owner.

Suggested citation:

Arihood, L.D., Lampe, D.C., Bayless, E.R., and Brown, S.E., 2019, Comparison of groundwater-model construction methods, representations of glacial geology, model designs, and groundwater-model flow simulations within Elkhart County, Indiana: U.S. Geological Survey Scientific Investigations Report 2019-5088, 44 p., https://doi.org/10.3133/ sir20195088.

ISSN 2328-0328 (online) 


\section{Acknowledgments}

The authors appreciate the support for this project from Greg Olyphant and Kevin Spindler, Indiana University Center for Geospatial Data Analysis, who provided valuable advice that guided data preparation for the objective model of Elkhart County, Indiana.

The project funding was provided through the U.S. Geological Survey (USGS) Groundwater Resources Program. The authors thank the following USGS personnel for their review of this report: Daniel Feinstein (technical review; Upper Midwest Water Science Center) and Adel Haj (technical review; Central Midwest Water Science Center). 



\section{Contents}

Acknowledgments ……...................................................................................................................

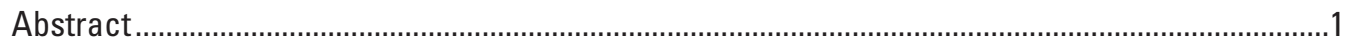

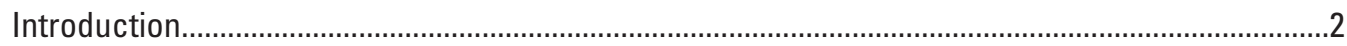

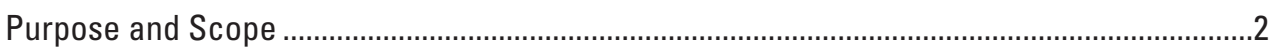

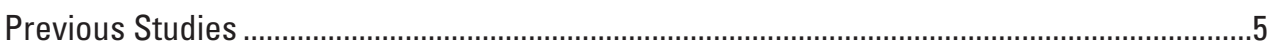

The Role of Geologic Detail in Groundwater Simulations.............................................5

Previous Studies in Elkhart County and the Surrounding Area ......................................5

Statistical Approaches to Hydrostratigraphic Frameworks ..............................................

Hydrostratigraphic Frameworks and Depositional Environment.....................................6

Limitations of Digital Hydrostratigraphic Frameworks .................................................

Comparing Hydrostratigraphic Frameworks and Measured Geology...............................7

Description of the Glacial Geologic Setting of the Study Area .................................................7

Comparison of Groundwater Model Construction Methods ..........................................................

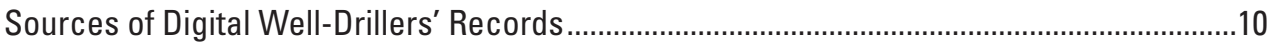

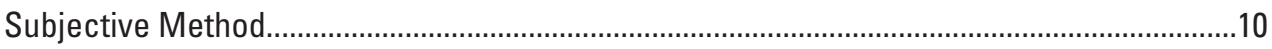

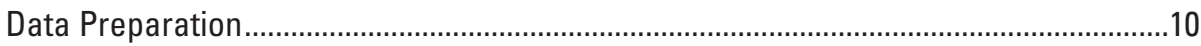

Development of Subjective Hydrostratigraphic Framework ...........................................10

Capabilities and Limitations of the Subjective Method .................................................12

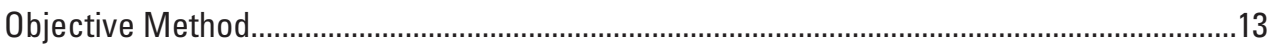

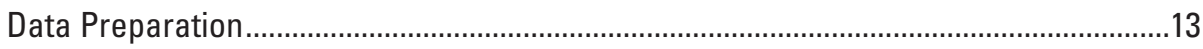

Development of Objective Hydrostratigraphic Framework ..............................................13

Capabilities and Limitations of the Objective Method ..................................................15

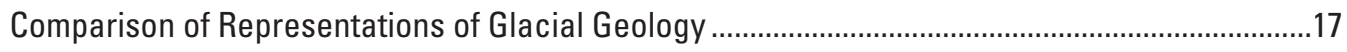

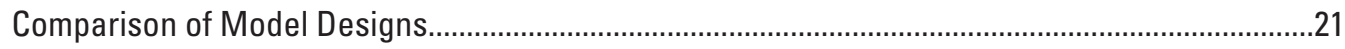

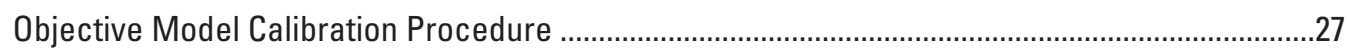

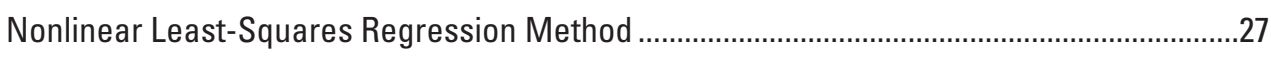

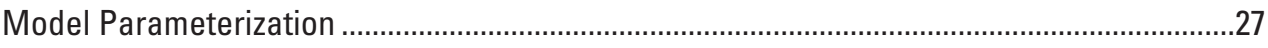

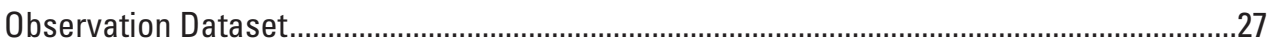

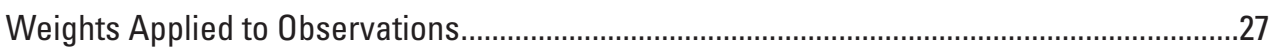

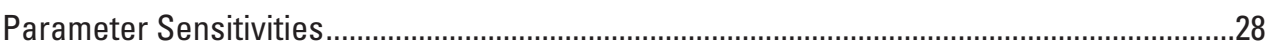

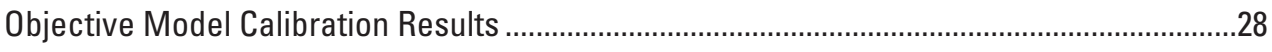

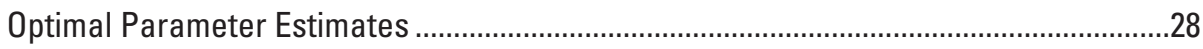

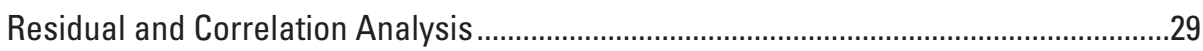

Comparison of Groundwater-Model Flow Simulations ...............................................................30

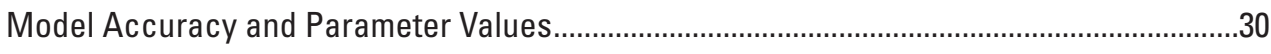

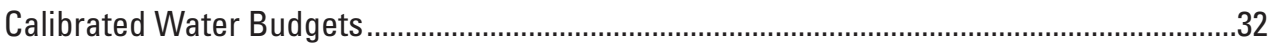

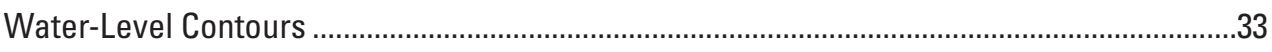

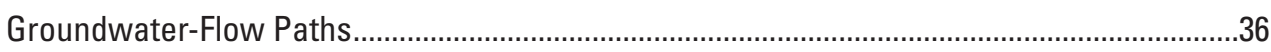

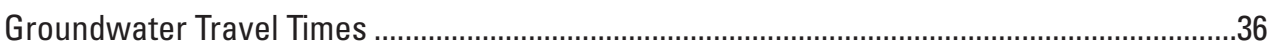

Model Limitations of the Objective and Subjective Models .....................................................36

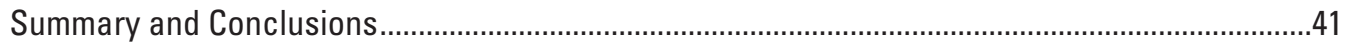

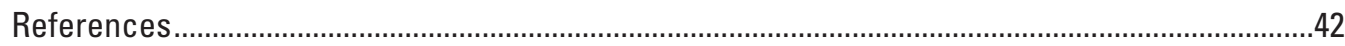




\section{Figures}

1. Map showing location of study area within the St. Joseph River Basin, northern Indiana and southwestern Michigan

2. Map showing location of Elkhart study area and local details.......................................4

3. Map showing surface geology of the Elkhart study area ...............................................

4. Map showing locations of drillers' well records used to construct the objective groundwater model within the study area, Elkhart County, Indiana ................................1

5. Graph showing example assignment of horizontal hydraulic conductivity code to a well $\log$

6. Three-dimensional representation of the distribution of geologic deposits and horizontal hydraulic conductivity codes for the study area in Elkhart County, Indiana

7. Diagrammatic section showing major hydrostratigraphic features and assumed direction of groundwater flow for the subjective method.

8. Map showing transmissivity for the upper aquifer in the Elkhart study area reflecting thickness of sand and gravel for the groundwater model of the subjective method

9. Map showing transmissivity for the lower aquifer in the Elkhart study area reflecting thickness of sand and gravel for the groundwater model of the subjective method

10. Map showing thickness of the confining unit in the Elkhart study area as depicted by the groundwater model for the subjective method

11. Geologic section along column 29 of the groundwater-flow model showing distribution of deposits derived from the groundwater model for the objective method.

12. Map showing model grid, boundary conditions, and types of stream nodes used in the simulation of groundwater flow in the Elkhart County, Indiana, study area

13. Diagrammatic section showing two model layers and boundary conditions used to represent major hydrogeologic units in Elkhart County, Indiana.

14. Map showing location of streamflow measurement sections and withdrawal facilities that pumped more than 100,000 gallons per day during 1993 in Elkhart County, Indiana

15. Graphical analysis of model fit for the objective model, $A$, weighted simulated and weighted measured water levels; $B$, normal probability plot of weighted residuals; and $C$, weighted residuals and weighted simulated values

16. Map showing differences between the nonweighted simulated and measured water levels for the objective model...

17. Map showing simulated water-level contours for the upper aquifer (layer 1) in the subjective model.

18. Map showing simulated water-level contours for layer 12 in the objective model ........35

19. Map showing flow lines representing the path of groundwater from points of recharge to points of discharge for the subjective model.

20. Map showing flow lines representing the path of groundwater from points of recharge to points of discharge for the objective model

21. Map showing location of the cross section along column 29 of the model grid .............39

22. Cross-sectional flow diagram along column 29 for the subjective model and the objective model 


\section{Tables}

1. Textural classification of geologic deposits used to define an aquifer or a confining unit in the Elkhart study area .

2. Well record descriptors and horizontal hydraulic conductivities used in objective model

3. Kriging parameters estimated by Environmental Visualization System (EVS) software package for the study area ................................................................................ 15

4. Model parameters used for the objective model and their initial values .........................24

5. Values used for objective model parameters .....................................................................29

6. Model accuracy in groundwater levels for the subjective and objective models ..........32

7. Water budget for the subjective model determined by steady-state simulation,

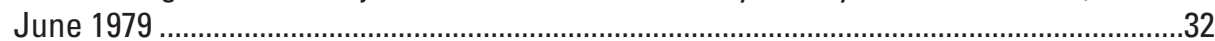

8. Water budget for the objective model determined by steady-state simulation,

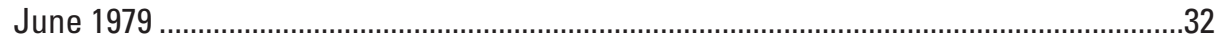

9. Comparison of simulated streamflow gain or loss to measured values for the subjective and objective model.... 


\section{Conversion Factors}

U.S. customary units to International System of Units

\begin{tabular}{|c|c|c|}
\hline Multiply & By & To obtain \\
\hline \multicolumn{3}{|c|}{ Length } \\
\hline inch (in.) & 2.54 & centimeter $(\mathrm{cm})$ \\
\hline inch (in.) & 25.4 & millimeter (mm) \\
\hline foot $(\mathrm{ft})$ & 0.3048 & meter $(\mathrm{m})$ \\
\hline mile (mi) & 1.609 & kilometer $(\mathrm{km})$ \\
\hline \multicolumn{3}{|c|}{ Area } \\
\hline square mile $\left(\mathrm{mi}^{2}\right)$ & 259.0 & hectare (ha) \\
\hline square mile $\left(\mathrm{mi}^{2}\right)$ & 2.590 & square kilometer $\left(\mathrm{km}^{2}\right)$ \\
\hline \multicolumn{3}{|c|}{ Volume } \\
\hline gallon (gal) & 3.785 & liter (L) \\
\hline gallon (gal) & 0.003785 & cubic meter $\left(\mathrm{m}^{3}\right)$ \\
\hline cubic foot $\left(\mathrm{ft}^{3}\right)$ & 0.02832 & cubic meter $\left(\mathrm{m}^{3}\right)$ \\
\hline \multicolumn{3}{|c|}{ Flow rate } \\
\hline foot per day $(\mathrm{ft} / \mathrm{d})$ & 0.3048 & meter per day $(\mathrm{m} / \mathrm{d})$ \\
\hline cubic foot per second $\left(\mathrm{ft}^{3} / \mathrm{s}\right)$ & 0.02832 & cubic meter per second $\left(\mathrm{m}^{3} / \mathrm{s}\right)$ \\
\hline gallon per day (gal/d) & 0.003785 & cubic meter per day $\left(\mathrm{m}^{3} / \mathrm{d}\right)$ \\
\hline inch per year (in/yr) & 25.4 & millimeter per year $(\mathrm{mm} / \mathrm{yr})$ \\
\hline \multicolumn{3}{|c|}{ Hydraulic conductivity } \\
\hline foot per day (ft/d) & 0.3048 & meter per day $(\mathrm{m} / \mathrm{d})$ \\
\hline \multicolumn{3}{|c|}{ Hydraulic gradient } \\
\hline foot per mile ( $\mathrm{ft} / \mathrm{mi}$ ) & 0.1894 & meter per kilometer $(\mathrm{m} / \mathrm{km})$ \\
\hline \multicolumn{3}{|c|}{ Transmissivity } \\
\hline foot squared per day $\left(\mathrm{ft}^{2} / \mathrm{d}\right)$ & 0.09290 & meter squared per day $\left(\mathrm{m}^{2} / \mathrm{d}\right)$ \\
\hline \multicolumn{3}{|c|}{ International System of Units to U.S. customary units } \\
\hline \multirow[t]{2}{*}{ Multiply } & By & To obtain \\
\hline & \multicolumn{2}{|l|}{ Length } \\
\hline meter $(\mathrm{m})$ & 3.281 & foot $(\mathrm{ft})$ \\
\hline kilometer $(\mathrm{km})$ & 0.6214 & mile (mi) \\
\hline \multicolumn{3}{|c|}{ Hydraulic conductivity } \\
\hline centimeters per second $(\mathrm{cm} / \mathrm{s})$ & 2,834 & foot per day $(\mathrm{ft} / \mathrm{d})$ \\
\hline
\end{tabular}

Selected altitudes include a reference to the National Geodetic Vertical Datum of 1929 (NGVD 29), as specifically described in the report text.

Horizontal coordinate information is referenced to the North American Datum of 1983 (NAD 83).

Altitude, as used in this report, refers to distance above the vertical datum. 


\section{Supplemental Information}

*Transmissivity: The standard unit for transmissivity is cubic foot per day per square foot times foot of aquifer thickness $\left(\left[\mathrm{ft}^{3} / \mathrm{d}\right] / \mathrm{ft}^{2}\right) \mathrm{ft}$. In this report, the mathematically reduced form, foot squared per day $\left(\mathrm{ft}^{2} / \mathrm{d}\right)$, is used for convenience.

\section{Abbreviations}

$\begin{array}{ll}\text { AML } & \text { ARC Macro Language } \\ \text { ASCII } & \text { American Standard Code for Information Interchange } \\ \text { cSS } & \text { composite scaled sensitivities } \\ \text { EVS } & \text { Environmental Visualization System } \\ \text { GWSI } & \text { Groundwater Site Inventory } \\ \text { NGVD 29 } & \text { National Geodetic Vertical Datum of 1929 }\end{array}$





\title{
Comparison of Groundwater-Model Construction Methods, Representations of Glacial Geology, Model Designs, and Groundwater-Model Flow Simulations within Elkhart County, Indiana
}

\author{
By Leslie D. Arihood, ${ }^{1}$ David C. Lampe, ${ }^{1}$ E. Randall Bayless, ${ }^{1}$ and Steven E. Brown ${ }^{2}$
}

\section{Abstract}

Automated data-processing methods allow hydrologists to efficiently incorporate digital well-record datasets into the construction of hydrostratigraphic frameworks for groundwater-flow models. The method selected to construct the hydrostratigraphic framework can affect the extent of geologic heterogeneity that can be included in the model. The detail generated from a hydrostratigraphic framework can affect groundwater simulation results. The effects of detail on model accuracy, groundwater-flow simulations, and particle-tracking simulations are described in this study. This report compares differences in hydrostratigraphic frameworks and results of groundwater models using (1) a method that incorporates more hydrologic judgment at the expense of using limited lithologic data and (2) a method that is more automated and uses all available lithologic data. The study additionally evaluates the effect of model discretization and inclusion of more (or less) geologic detail on simulation results.

Two methods were used to create hydrostratigraphic frameworks of glacial deposits in the St. Joseph River Basin. One method, referred to as the subjective method, manually identifies stratigraphic boundaries using a sample of well logs from State databases and uses two-dimensional kriging to create three model layers of the study area. Indicator kriging is used to define aquifer extent in each layer. The second method, referred to as the objective method, uses three-dimensional kriging to automatically create a detailed heterogeneous model of the study area using all wells logs from the State database. The objective method increases detail in the vertical by greatly increasing the number of computer groundwater model layers from 3 to 30. In Elkhart County, Indiana, a previously published model represents the product of the subjective method, and a newly calibrated model of the same area represents the product of the objective method.

${ }^{1}$ U.S. Geological Survey.

${ }^{2} I 1 l i n o i s$ State Geological Survey.
An automated calibration procedure was used with the objective model (derived from the objective method) for Elkhart County. The two most-sensitive parameters for the Elkhart County objective model are horizontal hydraulic conductivity of the sand and the combined sand and gravel/gravel deposits. Vertical hydraulic conductivity of the fine-grained and intermediate-sized deposits could not be estimated, possibly indicating major flow paths are along a continuously connected series of sand and gravel deposits and not through a confining layer.

The statistics measuring model calibration accuracy for the objective model were slightly better than statistics for the subjective model (model derived from the subjective method) of Elkhart County, but the hydraulic conductivities and flow rates for the two models were different. The mean absolute errors between simulated and measured groundwater levels are 2.04 and 2.16 feet for the objective and subjective models, respectively. Simulated seepage losses from and groundwater discharges to measured stream reaches in the objective model were evenly balanced in terms of over and under simulations of measured values; the subjective model tended to overpredict measured groundwater discharge to streams. The overprediction may be related to the 58 percent greater total inflow and outflow through the subjective model. The greater flow rate through the subjective model results from higher horizontal hydraulic conductivities in the subjective model than in the objective model. Horizontal hydraulic conductivity ranged from 23.9 to 111 feet per day in the objective model and generally ranged from 170 to 370 feet per day in the subjective model. The improvement in calibration statistics for the objective model relative to the subjective model may be from increased detail in how the objective model represents the distribution of fine- and coarse-grained deposits. The improvement also could be associated with the difference in methods used to represent the continuity of the confining unit.

The effect of differences in horizontal hydraulic conductivity distributions between the two models for Elkhart County is evident in the groundwater-flow paths simulated by the objective and subjective models. At a withdrawal well 
location, the flow lines produced by the objective model indicate a wider contributing area than that for the subjective model. The discontinuous confining unit represented in the objective model provided the opportunity for groundwater flow to split into an upper and lower path. The split in flow simulated by the objective model at one location was independently supported by bromide concentrations in groundwater; the subjective model did not duplicate the split in flow.

\section{Introduction}

The U.S. Geological Survey (USGS), through its Groundwater Resources Program has the responsibility to assess the availability of groundwater resources at the regional and national scale (Dennehy, 2005). An area of interest for the Groundwater Resources Program is the unconsolidated glacial deposits of the St. Joseph River Basin, a subbasin within the Lake Michigan Basin (fig. 1). The unconsolidated aquifers in this basin are significant sources of drinking water, are influential factors in water quality and availability in the Great Lakes (not shown), and are highly susceptible to droughts and contamination (U.S. Geological Survey, 1998; Grannemann and others, 2000). The specific interest of the Groundwater Resources Program in the St. Joseph River Basin is to develop and refine tools to construct groundwater models in glacial environments.

Most groundwater flow in parts of the Lake Michigan Basin east of Lake Michigan (fig. 1) is in the glacial deposits as opposed to the underlying bedrock (Mandle and Kontis, 1992, p. 92). Representing the distribution of aquifer and nonaquifer deposits and their water-bearing characteristics in the glacial deposits is important to the accuracy of model simulations of groundwater-flow volume, direction, and velocity. The complex distribution of glacial deposits is frequently difficult to represent in groundwater-flow models because many observation points are needed to define the extent of intermittent zones of aquifer and nonaquifer deposits. Abundant data that can provide information on aquifer deposits are available from the well logs provided by water-well drillers to State digital databases. These data can be reprocessed and analyzed by hydrologists and computer programs to create frameworks of aquifers and confining units (hydrostratigraphic frameworks) that are suitable for constructing groundwater-flow models.

The method selected to construct the hydrostratigraphic framework can affect the degree of geologic heterogeneity that can be included in the model. The groundwater simulation results can be, in turn, affected by the detail generated from the hydrostratigraphic framework. The effects of detail and methodology used to model glacial deposits on the results of groundwater-flow and particle-tracking simulations are described in this study.

Two methods were used to create hydrostratigraphic frameworks of glacial deposits in the St. Joseph River Basin. One method, referred to as the "subjective method", manually identified stratigraphic boundaries and used two-dimensional kriging to create model layers of the study area. The subjective method, described in Arihood and Cohen (1998), used the Geographical Information System software ArcInfo, version 8.3 (Environmental Systems Research Institute, 2003). The second method, referred to as the "objective method", used three-dimensional kriging to automatically create complex models of the study areas. The objective method used the Environmental Visualization System (EVS) software by C Tech Development Corporation (C Tech, 2008). Both methods have been used in previous studies of groundwaterflow systems to generate geologic interpretations (Arihood and Cohen, 1998; Kim and others, 2002). The U.S. Environmental Protection Agency has completed verification testing of EVS to determine that the software generates geologic interpretations of adequate quality and defensibility (Cross and others, 2005, p. 13).

The subjective and objective methods of developing hydrostratigraphic frameworks were both applied to an area of northwestern Elkhart County, Indiana (figs. 1 and 2). The geology of northwestern Elkhart County has been described as a Pleistocene outwash deposit bounded on the north, south, and southeast by till plains that include ice-contact stratified drift and ground moraine deposits (Johnson and Keller, 1972; Schneider and Keller, 1970).

\section{Purpose and Scope}

The purpose of this report is to present results on the effect of model-construction methods and their associated incorporation of geologic detail on the output of groundwater models applied to a glacial geologic setting. Specifically, the report will (1) describe two methods used to construct digital hydrostratigraphic frameworks from databases of water-welldrillers' records; (2) describe the benefits and limitations of the two methods; (3) report evaluations of hydrostratigraphy for northwestern Elkhart County, Ind., by geologists familiar with the depositional settings of the study areas; (4) describe the ability of models constructed from each method to duplicate the distribution of glacial deposits and field observations of water level and groundwater discharge; and (5) elucidate the similarities and differences in groundwater-flow and particle-tracking simulations generated from the two hydrostratigraphic frameworks. Previous studies have assessed the value of geologic detail to the accuracy of groundwater models. This report compares the accuracy and utility of two groundwater models for northwestern Elkhart County. Of the two models, one model used a hydrostratigraphic framework created from a more time-consuming construction method that incorporates hydrogeologic judgment and less geologic detail (the subjective method). The other model used a hydrostratigraphic framework created from a less time-consuming, moreautomated approach that uses more geologic information and geologic detail (the objective method). 


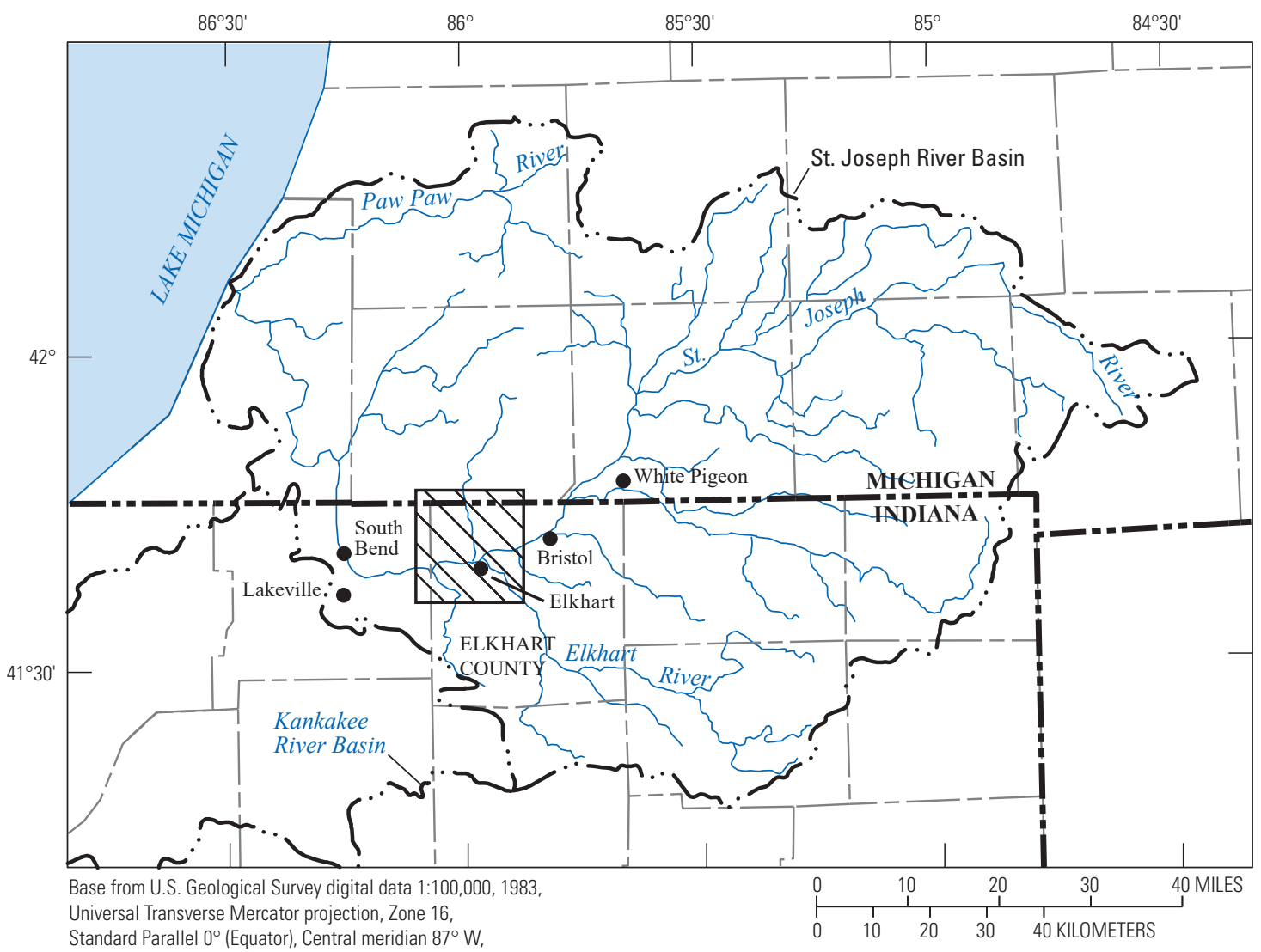

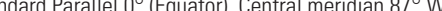

North American Datum of 1983.
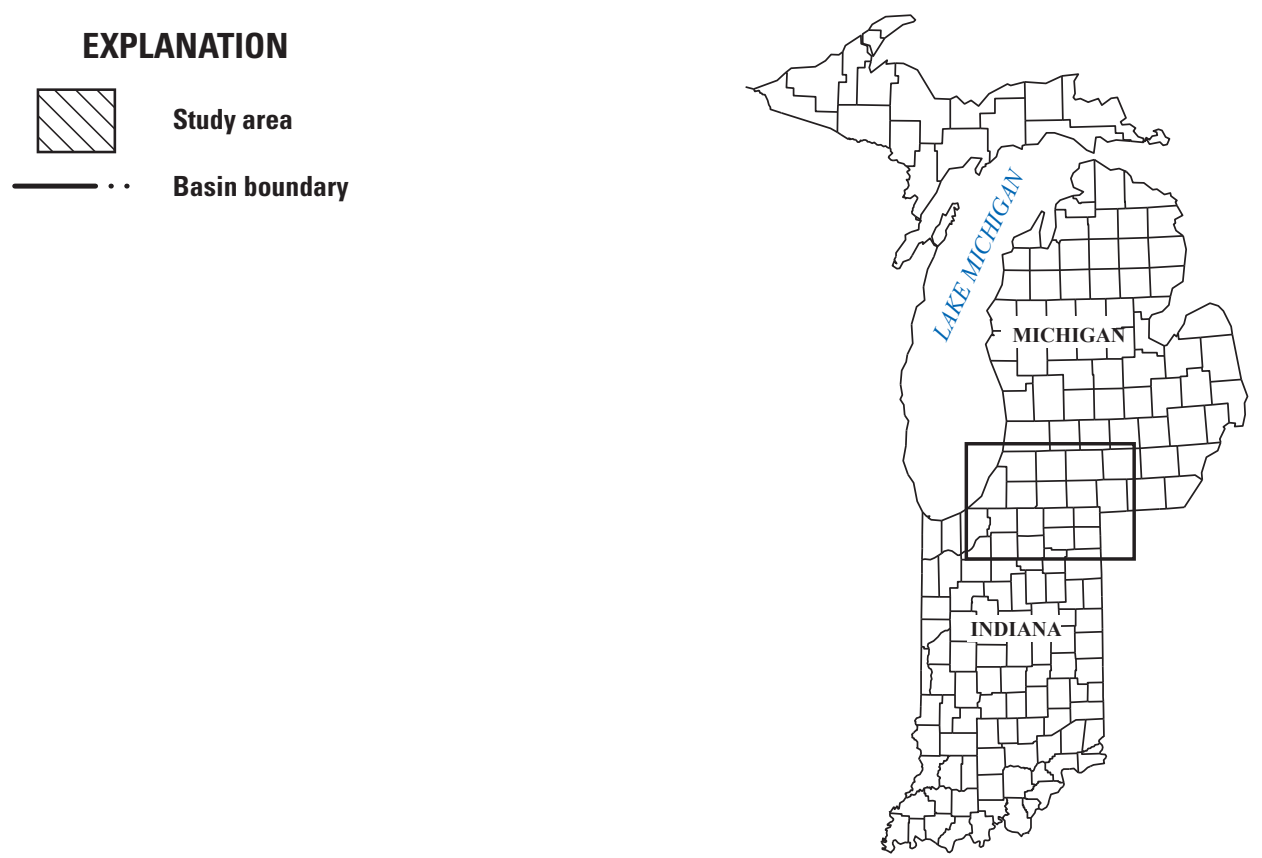

Figure 1. Location of study area within the St. Joseph River Basin, northern Indiana and southwestern Michigan. 


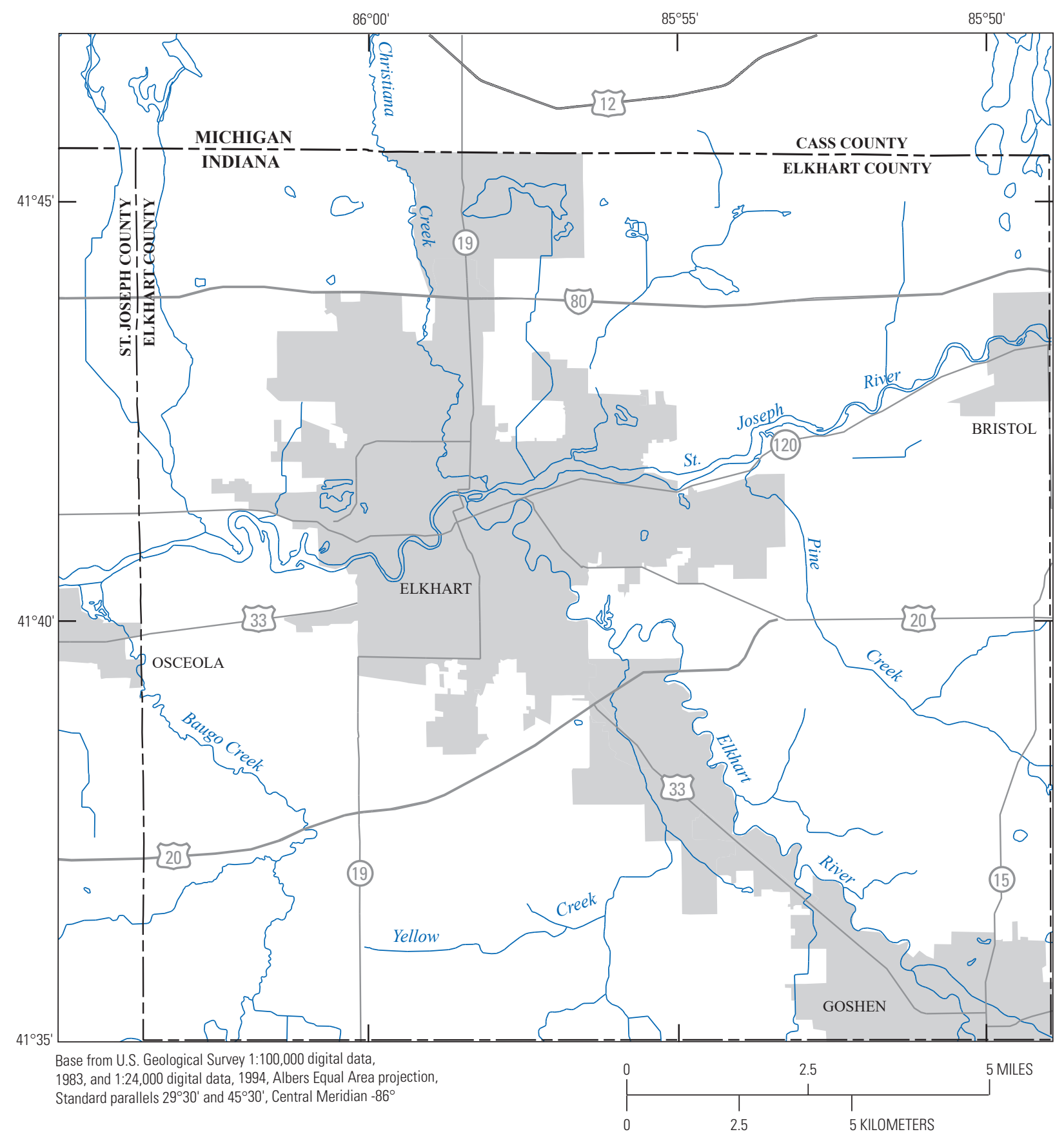

EXPLANATION

Incorporated urban and developed areas

Figure 2. Location of Elkhart study area and local details. 
The study area is in the St. Joseph River Basin, a major drainage to Lake Michigan. The study area includes about 191 square miles of northwestern Elkhart County, Ind., and adjoining counties in the St. Joseph River Basin (fig. 1). Only the glacial deposits were examined; the underlying shale was considered a nonaquifer and acted as the bottom of the flow system.

\section{Previous Studies}

Construction of groundwater-flow models requires decisions on the geologic detail of the groundwater-flow simulations and an appropriate approach to create the hydrostratigraphic framework of aquifer and nonaquifer deposits. The goal of these decisions is to have the resulting hydrostratigraphic framework reflect the physical properties of the depositional environment even though the number of point measurements used to describe the geology may be limited.

\section{The Role of Geologic Detail in Groundwater Simulations}

The value of geologic detail increases as the study area becomes smaller, the geology becomes more heterogeneous, and the hydrologic model is applied to more complex tasks (Desbarats, 1990; Ritzi and others, 2000; Weissmann and others, 2002). The level of geologic detail required to accurately simulate groundwater flow should increase from a regional, geologically uniform, steady-state, groundwater-flow model to a site specific, geologically complex, transient model of solute transport (Martin and Frind, 1998). Accordingly, regional studies of water-mass balance may be adequately calibrated by representing general features, whereas local studies will require spatially dense datasets that can represent all deposits of contrasting hydraulic conductivity.

Grouping hydraulic parameters may be justified given the objective of regional groundwater-flow models and may not appreciably sacrifice simulation accuracy. Although fracture geometry controlled the local flow system for a model of fractured-rock terrains, Nastev and others (2004) determined that a hydrostratigraphic framework representing an equivalent porous media was suitable for a regional model. In a regional study of a heterogeneous alluvial formation (Zhang and Brusseau, 1998), 12 textural classes were used to construct the hydrostratigraphic framework in groundwater-flow and transport simulations, and the determination was that reasonable groundwater-flow models could be attained by grouping the 12 classes into 2 (high and low) permeability units. The boundary between the two units was defined by Zhang and Brusseau (1998) to be a horizontal hydraulic conductivity of 0.0283 foot per day (ft/d). Similarly, the horizontal hydraulic conductivity data from fluvial deposits of the Wilcox aquifer system in Texas were determined to be represented in simulations of groundwater flow by a bimodal horizontal hydraulic conductivity distribution (Fogg, 1986). The importance of accurately representing the degree of connectivity of the higher-permeability deposits to accurate simulation of groundwater flow paths was emphasized by Fogg (1986).

To evaluate the effects of geologic detail in unconsolidated units on groundwater-flow simulations, six regional hydrostratigraphic frameworks were compared by Harrar and others (2003). The study determined that the mean horizontal hydraulic conductivity of all models were nearly identical and could adequately reproduce the measured groundwater levels; therefore, not much improvement in simulation of groundwater levels was produced by including additional geologic complexity. Solute-transport simulations based on the same hydrostratigraphic frameworks, however, indicated that geologic complexity affected travel times from point of recharge to time of discharge from a pumped well, which varied among the hydrostratigraphic frameworks from 553 to 2,144 years (Harrar and others, 2003). In contrast to the results of Harrar and others (2003) successfully using a mean horizontal hydraulic conductivity in a unconsolidated aquifer, results of a statistical study by Desbarats and Bachu (1994) indicated that using an arithmetically averaged horizontal hydraulic conductivity for a sandstone- and shale-dominated aquifer system resulted in overestimated values of aquifer transmissivity.

Geologic detail may be important to studies that require fine resolution of simulation results, simulate water levels and flow in small study areas, contain highly heterogeneous geologic deposits, simulate solute transport, or require timedependent (transient) simulations (Anderson, 1989). For these model uses, grouping the properties of heterogeneous units into effective hydraulic parameters may limit the value of model simulations (Ritzi and Dominic, 1993; Ritzi and others, 1994). The arrangement and interconnectedness of highpermeability deposits, such as fluvial sand bodies, may have a greater effect on contaminant transport than the hydraulic conductivity of the geologic units (Fogg, 1986). Including the geometric details of interconnected high-permeability facies (preferential flow pathways) may be necessary to reasonably simulate groundwater flow and transport in some locales (Anderson, 1989). One or two well-connected sands among a system of otherwise-disconnected sands can completely alter a velocity field (Field, 1991). For purposes of contaminanttransport modeling, Ritzi and others (1995) determined that an existing stratigraphic framework of the Miami River Basin that represented the deposits as three layers (two aquifers and one intervening confining unit) would be better envisioned as one aquifer with aquitard deposits interspersed at all elevations.

\section{Previous Studies in Elkhart County and the Surrounding Area}

The geology, water use, water budget, flood and lowflow data, and the quality of ground and surface waters in the St. Joseph River Basin, which includes the study area, were illustrated in three plates by Reussow and Rohne (1975). The 
general groundwater hydrology and quality of the Elkhart area were described by Imbrigiotta and Martin (1981), including the hydrologic effects of proposed pumping at Elkhart Municipal Airport, and the potential for leachate from a landfill to enter the proposed well field. Groundwater levels (68 sites) and water quality (32 sites) from a 10-year monitoring program in the Elkhart area were described by Duwelius and Silcox (1991). The distribution of dissolved bromide with time was used to delineate the approximate boundary of a leachate plume from a landfill discussed by Imbrigiotta and Martin (1981) and to estimate groundwater travel time. The effect of pumpage on water levels in the unconsolidated outwash aquifer at the Main Street Well Field were illustrated by Duwelius and Watson (1992) in five water-level contour maps from December 18-22, 1989. A groundwater-flow model of the Elkhart, Ind., area (fig. 1) was developed to determine the availability and source of water at potential new well fields (Arihood and Cohen, 1998).

\section{Statistical Approaches to Hydrostratigraphic Frameworks}

The objective and subjective methods in this study used geostatistical methods to make spatial correlations among water well-drillers' records of subsurface geology. Ordinary, indicator point kriging and indicator conditional kriging have been commonly used to describe the spatial correlation of geologic data (Proce and others, 2004). Indicator geostatistics are best used with existing geologic information to model geologic facies and the hydraulic conductivity distribution (Fogg and others, 1998; Weissmann and Fogg, 1999; Proce and others, 2004). Ritzi and others (1994) used three indicator point kriging methods at a heterogeneous glaciofluvial aquifer in southwestern Ohio to evaluate geologic uncertainty and its effect on hydrologic models. Johnson and Dreiss (1989) determined that indicator kriging could be used to estimate uncertainty in hydrostratigraphic interpolations; the kriged 0.5 contours of uncertainty were near interpolated geologic boundaries. Additionally, Johnson and Dreiss (1989) indicated that experimental variograms were generally reliable only for lags (distances between data pairs used to calculate the variogram) equal to or less than one-half the aerial extent of the data (Journel and Huijbregts, 1978).

\section{Hydrostratigraphic Frameworks and Depositional Environment}

Several studies have determined that the accuracy of groundwater-flow and transport models can be improved by constructing the hydrostratigraphic framework in the context of the depositional setting (Anderson, 1989). The hydraulic properties of aquifers, which control model simulations, vary spatially as a result of the complex geologic processes that formed the properties (Zhang and Brusseau, 1998). Those processes are captured in the depositional history and include sediment diagenesis and fracturing (Fogg, 1986). The spatial variability of the hydraulic properties leads to spatially variable pore water velocities, which affect contaminant transport in the subsurface (Zhang and Brusseau, 1998). Characterizing the spatial distribution of hydraulic conductivity, therefore, is critical to the accurate representation of flow and transport (Zhang and Brusseau, 1998).

Characterizing the three-dimensional distribution of hydraulic properties strictly from information generated at discrete well points can be problematic. Fogg and others (1998) determined that conventional textural classifications, such as those that might be interpreted from well-drillers' records, did not correlate well with hydraulic conductivity distributions needed to generate accurate groundwater-flow models. Refinement of textural classifications into a framework consistent with the depositional setting, however, yielded a correlation with hydraulic conductivity that was useful for creating a numerical framework of a complex geologic setting (Fogg and others, 1998). The benefits of considering depositional setting can be partially attributed to the observation that facies dimensions are commonly smaller than the lateral spacing of well records. Fogg and others (1998) indicated that the facies approach should improve the hydrologist's depiction of the three-dimensional hydraulic conductivity, particularly in areas where geologic studies have characterized the depositional environment. Proce and others (2004) indicated that multiple hydrostratigraphic frameworks of a single study area are useful for identifying a model that best simulates groundwater transport data. The application of conceptual depositional environments to stratigraphic modeling has been widely used by the petroleum industry but has not been fully integrated in hydrologic studies (Fogg, 1986).

\section{Limitations of Digital Hydrostratigraphic Frameworks}

The processes for creating digital hydrostratigraphy and incorporating the numerical framework into groundwater models have limitations. Factors limiting the creation of an accurate hydrostratigraphic framework include the availability and quality of well-drillers' records, spatial distribution of the records, partial penetration of water-bearing units, conventions for converting geologic information from well-drillers' records into hydraulic parameters, matching model grids to geologic boundaries, and the hydrologist's ability to deduce the depositional environment and integrate those concepts into the models.

The availability of digital well-drillers' records may restrict the amount of accessible information for building hydrostratigraphic frameworks. The legal requirements imposed on well drillers differ from state to state. For example, the State of Indiana has required well drillers to submit written records since the 1980s; the State transposes the information into a managed database that is available for public use (Indiana Department of Natural Resources, 2019). 
The State of Michigan requests that well drillers submit records to a State or local agency; the result eventually is a single, comprehensive database named Wellogic (Michigan Department of Environmental Quality, 2017). Many states also maintain repositories for records of wells drilled for oil and gas exploration, such as the Petroleum Database Management System maintained by the Indiana Geological and Water Survey (2019). These records, however, generally do not include detailed descriptions of the unconsolidated deposits. Different states use unique software systems to retrieve and format digital well-drillers' records.

Unequal distribution and quality of well-drillers' records may create areas where confidence in the digital geology is poor but is not apparent in the model results; hydrogeologists may censor those records that seem unreliable. Yet, eliminating records can further complicate issues related to spatial distribution and may add additional bias to the analysis (Proce and others, 2004). As an alternative, Proce and others (2004) suggested using the complete set of well-drillers' records with an understanding of the distribution and nature of the errors.

The quality of lithologic descriptions and classifications of stratigraphic breaks in well-drillers' records is highly variable and may limit the usefulness of some data. The accuracy of output from kriging routines used to interpolate stratigraphic boundaries may be decreased by inaccurate lithologic descriptions or inconsistent notation of stratigraphic breaks. Utility computer programs have been created to filter out welldrillers' records with obvious errors, such as bedrock overlying unconsolidated material, but the programs are incapable of classifying the accuracy of the well-drillers' interpretation of geologic deposits.

Converting information from well-drillers' records into data that can be used to build hydrostratigraphic frameworks can be problematic (Ritzi and others, 2000; Proce and others, 2004). The maximum depth of many well-drillers' records is the depth of the shallowest aquifer that produces water sufficient for the designated use. The desired basal boundary for most groundwater models is the impermeable unit that underlies the deepest aquifer deposit. The intervening thickness of geologic deposits between the bottom of the well-drillers' record and the lower model boundary must be postulated based on information describing the geologic setting. Semiautomated methods for constructing digital geology will require user intervention to create a framework consistent with the geologic-setting information.

Assigning hydraulic properties to geologic deposits described in the well-drillers' records is also an imprecise science; however, parameter-estimation techniques used during a model calibration can provide horizontal hydraulic conductivity estimates for aquifers mapped using driller logs. Generally, aquifer tests in constructed wells target permeable aquifer material and may not highly stress the water-producing potential of the system. As a result, aquifer tests may not provide an adequate representation of the horizontal hydraulic properties of the entire aquifer and do not estimate hydraulic properties for the fine-grained deposits that typically comprise a large part of the hydrostratigraphic framework (Fogg and others, 1998; Zhang and Brusseau, 1998; Johnson and Dreiss, 1989).

Zhang and Brusseau (1998) identified grid spacing as a potential source of error in hydrostratigraphic frameworks; coarse grids were unable to capture geologic heterogeneity and occasionally straddled stratigraphic boundaries. Fogg and others (1998) attempted to compute a hydraulic conductivity distribution using 5-, 10- and 0.5- meter spacings in the $\mathrm{x}, \mathrm{y}$, and $\mathrm{z}$ directions, respectively, for an area 1.5 by 1.5 by 0.1 kilometers at the Lawrence Livermore National Laboratory. That resolution was considered necessary by Carle and Fogg (1996) to accurately represent advection-dispersion processes in groundwater flow. Grid spacing (or model domain discretization) also must be chosen to accurately address the problem being considered. A coarse grid may be sufficient to simulate a homogeneous and isotropic sand deposit, but even in that geologic setting, a fine grid may be required to examine solute transport along gradients near hydrologic boundaries or discharge areas.

\section{Comparing Hydrostratigraphic Frameworks and Measured Geology}

Previous studies have assessed the accuracy of hydrostratigraphic frameworks developed with automated methods to the actual hydrostratigraphy. Geologic cross sections generated by computer methods compared favorably with cross sections drafted by geologists (Zhang and Brusseau, 1998). Johnson and Dreiss (1989) used geostatistics to interpret hydrostratigraphic boundaries and concluded that the 50 percent probability contour for the presence of aquifer material corresponded to the author's subjectively drawn stratigraphic boundaries between aquifer and nonaquifer material. Proce and others (2004) applied geostatistical adjustments to hydrostratigraphic frameworks created with transitional-probability methods to elongate highly permeable units to improve the unit's agreement with depositional-setting models.

\section{Description of the Glacial Geologic Setting of the Study Area}

The study area is in Elkhart County, Ind., in the southcentral part of the St. Joseph River Basin (figs. 1 and 2). The northern and southern flanks of the St. Joseph River valley in the Elkhart study area are glacial-fluvial terraces formed by meltwater exiting the Huron-Erie and Saginaw lobe margins in northeastern Indiana and central Michigan (Russell and Leverett, 1908, p. 10). The St. Joseph River system focused meltwater along ice-margin segments nearly 150 miles during retreat of the Huron-Erie ice margins. Much of this meltwater was focused through the Elkhart study area. Local parts of the terraces are covered by colluvial and alluvial hillslope deposits emanating from gullies along the valley walls. The near surface sediment terraces are underlain by fluvial sand and gravel and lesser amounts of finer colluvial deposits. 
The St. Joseph River valley is generally incised into late-Wisconsinan and older glacial deposits along the southern valley wall and into late-Wisconsinan fan and delta sediment along the north valley wall. The valley sediment is composed of far-traveled outwash with modern alluvium. The valley is in areas where the retreats and advances of three or four late-Wisconsin ice margins coincided. In this valley, a minor retreat of one ice-margin sometimes coincided with the advance of another, producing complex and locally inconsistent overlap of sequences. The western edge of the glacially scoured basin is about 8 miles west of the study area where most of the glacial deposits are late-Wisconsin in age. Because the area was always an ice-marginal or pro-glacial environment during glacial events, the segment of the St. Joseph River valley from South Bend, Ind., (fig. 1) upstream to the eastern edge of the study area could be underlain by fluvial sediment that is much older than the last, late-Wisconsin glacial events. This segment of the river valley may have been a meltwater drainageway during earlier, pre-Wisconsin glacial events. The sediment beneath the St. Joseph River valley in this segment is predominantly fluvial sand and gravel, but the sediment is not a simple, single depositional sequence. Fluvial processes may have operated in part of the St. Joseph River valley for much of the Pleistocene, creating a complex assemblage of cut-and-fill sequences. The valley is underlain by remnant lake deposits, till, and till-like sediment that form discontinuous beds. The ages of the deposits are unknown.

Sediment in the St. Joseph River valley is chiefly coarsegrained fluvial outwash but contains smaller amounts of fine-grained sediment, including till and lake bed sediments (fig. 3). The sediment in the valley has an unconformable relation to the sediment that forms the southern valley wall and cannot be correlated with sediment beneath the upland to the south. Fluvial sediment in the St. Joseph River valley in the study area that was deposited by meltwater deposits during deglaciation is likely only 20 to 30 feet thick. Fluvial sediment below that depth was deposited during the onset of late-Wisconsin glaciation or is pre-Wisconsinan in age. The thickness of glacial deposits in the Elkhart study area generally ranges from 150 to 250 feet (ft) (Gray, 1983).

The glacial stratigraphy in the upland along the south side of the St. Joseph River valley is principally composed of fine-grained till and lake sediment. The surface sediment is late-Wisconsin in age and includes fine-grained lake sediment, glacial till, and fluvial sediment. Most of the underlying glacial sequences are older than the late-Wisconsin glaciation. Weathering profiles and organic beds are at elevations of about 800-850 ft above National Geodetic Vertical Datum of 1929 and higher and provide evidence of one or more former interglacial periods. In addition, the lower-most glacial sequence has characteristics of the oldest-known glacial sediment in Indiana. The top of the lower-most glacial sequence is at elevations from about 700 to $750 \mathrm{ft}$ above National Geodetic Vertical Datum of 1929 and consists mostly of fine-grained lake sediment and glacial till with not much fluvial sediment.
Sediment composition north of the St. Joseph River can be contrasted with composition south of the river. North of the river and at the surface is a broad outwash plain underlain by thick deposits of sand and gravel (fig. 3). South of U.S. Highway 20 and southwest of U.S. Highway 33 (fig. 3), the upland is underlain by a thin veneer of till, till-like sediment and lake sediment deposited in subglacial and near-ice environments of the Lake Michigan lobe. This sediment is very fine grained (chiefly silty clay, silty clay loam, and silt loam textures) and is not more than $30-\mathrm{ft}$ thick. Beneath this Lake Michigan lobe sediment is a package of till and fluvial sediment deposited by the Saginaw lobe. This particular Saginaw lobe till is coarser (loam, clay loam, and sandy clay loam) than the Lake Michigan lobe till. These late-Wisconsinan deposits are underlain by pre-Wisconsinan deposits of Illinoian and pre-Illinoian age. The near-surface sediment beneath the upland north and east of U.S. 33 and along the eastern edge of the Elkhart study area also is underlain by mostly fluvial Lake Michigan lobe deposits. The landforms are small outwash fan heads and the landscape includes many stagnant ice forms. These coarsegrained deposits are chaotic in form and lateral continuity of near surface units is variable. These upland landscapes are deeply incised by stream valleys that originated as proglacial meltwater streams flowing away from the Lake Michigan and later from the Huron-Erie lobe as it advanced into the region.

\section{Comparison of Groundwater Model Construction Methods}

Two methods for constructing groundwater models were tested and evaluated. The first method, the subjective method, used a system of programs written in ARC Macro Language (AML; Environmental Systems Research Institute, 2003) that were combined into a single menu-driven system on a Unix platform. In the subjective method, hydrologists used the AML programs to create a simple layered hydrostratigraphic framework used for a groundwater model of the study area. The second method, called the objective method, used commercially available software (Environmental Visualization System, or EVS, C Tech Development Corporation, 2008) to create a complex hydrostratigraphic framework used for a groundwater model of the study area. The EVS software operates on an Intel processor-based Windows platform and can be used for data visualization and for three-dimensional kriging. The objective method generated a complex, continuous distribution hydrostratigraphic frameworks. The AML programs and EVS software were used to convert the hydrostratigraphic frameworks from the subjective and objective methods into input files for the USGS modular groundwater-flow model. The groundwater-flow simulation program MODFLOW-96 (Harbaugh and McDonald, 1996) was used to calibrate the subjective model, and MODFLOW-2000 (Harbaugh and others, 2000) was used to calibrate the objective model. A particle-tracking post-processing package for MODFLOW, 


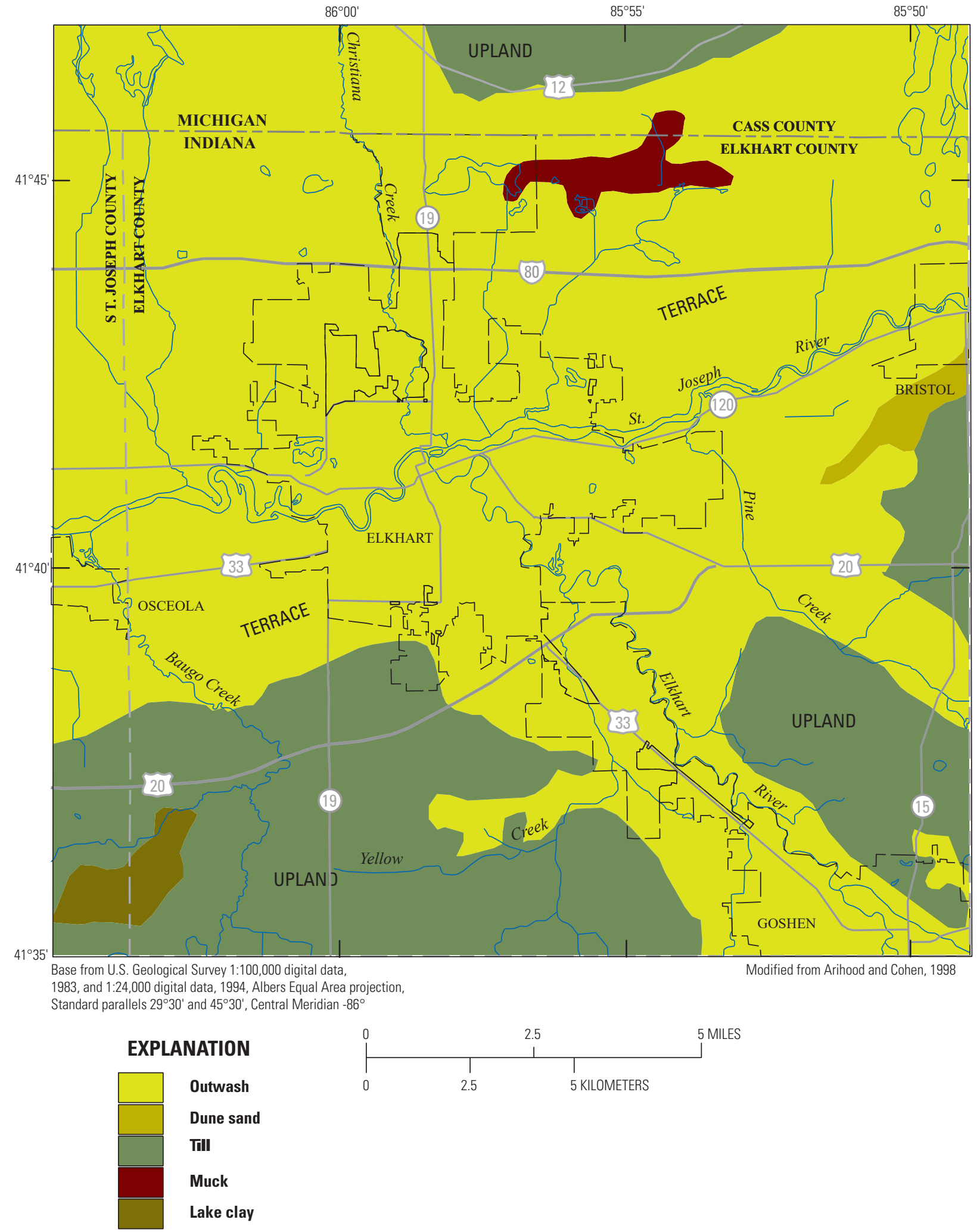

Figure 3. Surface geology of the Elkhart study area. 
MODPATH (Pollock, 1994), was used to generate threedimensional flow paths with different scenarios of the subjective and objective groundwater models. MODPATH computes paths for imaginary particles of water moving through a simulated groundwater system.

\section{Sources of Digital Well-Drillers' Records}

Databases managed by the Indiana Department of Natural Resources were used as sources of digital well-driller's records. About 3,300 well records were obtained for the modeled area of Elkhart and parts of adjacent counties in Indiana (fig. 4). The well locations shown in figure 4 represent data points used to construct the objective groundwater model. Only about 600 data points were used to construct the subjective groundwater model for the study area. Fewer data points were used to construct the subjective groundwater model because of the increased time required to manually analyze the well records.

\section{Subjective Method}

Conventional groundwater models with variable layer thickness have been a standard for groundwater models. The finite-difference groundwater-flow model known as MODFLOW-96 (Harbaugh and McDonald, 1996) was used on a Unix computer to simulate groundwater flow for the subjective model as described in Arihood and Cohen (1998). The model produced groundwater-flow simulations based on aquifers assigned to individual layers with confining material between the aquifers. Aquifer heterogeneity was incorporated within a layered system by varying the hydraulic conductivity and thickness of geologic units and by assigning a negligible thickness (such as $1 \mathrm{ft}$ ) where aquifer units pinch out. Model calibration was continued until improvements to simulated heads and fluxes were negligible.

\section{Data Preparation}

To prepare data for the construction of the hydrostratigraphic framework, the well-drillers' lithologic descriptions in the digital well records were translated into a standardized set of geologic terms that could be used for spatial correlation of aquifer and confining units. The well log dataset was processed with in-house AML programs that converted well-drillers' descriptions to a set of standardized textural descriptions. Well-drillers' descriptions of geologic deposits were renamed using textural classifications stored in the USGS Groundwater Site Information (GWSI) system (Mathey, 1989). Descriptions of geologic deposits and the corresponding textural classification and GWSI codes that were interpreted for the descriptions are listed in table 1 . The AML programs were used to scan the database, identify and eliminate records that were incomplete or duplicates or that contained obvious logical mistakes, indicated nonsequential depths, or included geological impossibilities. After the datasets were filtered, about 95 percent of the well-drillers' records remained in the Elkhart County dataset.

\section{Development of Subjective Hydrostratigraphic Framework}

A hydrostratigraphic framework was created to guide construction of the subjective computerized groundwater model by identifying the important components of the groundwater flow system. The components were identified before the construction of the groundwater-flow model was started. These components were based on information compiled by Arihood and Cohen (1998) and consisted of the thickness and altitude of two aquifers and an intervening confining unit, and the lateral continuity of the aquifers and confining unit. The upper and lower layers were comprised of sand and gravel with occasional lenses of clay and silt. The confining unit was a laterally continuous clay and silt-rich deposit that allowed vertical leakage between the layers. Component selection was improved by reviewing geologic literature for the study area and spatially viewing a subset of the well-drillers' records with AML programs.

For the subjective hydrostratigraphic framework, a hydrologist visually identified the upper and lower surfaces of the aquifer and nonaquifer layers. The layers were identified by the following process. Well records stored in an ArcInfo coverage were displayed as points on a computer screen in map view, and the hydrologist selected a series of well points to form a trace line. Well-drillers' lithologies for the chosen wells were then graphically depicted at the bottom of the same screen as stratigraphic columns aligned on a geologic cross section that followed the trace line. After viewing the lithologies in the cross section, individual deposits of aquifer shown for each well were grouped into a specific hydrostratigraphic layer. Next, individual wells in the cross section were selected so that the aquifer deposits associated with the well could be assigned to a layer. Once a well was selected, altitude data for each lithologic record were automatically listed out from the well $\log$ dataset onto the computer screen. The listed altitudes for the top and bottom of the aquifer were assigned to the individual well, then the process was repeated for the next well in the cross section. The presence and absence of each layer also was noted with either a 1 (present) or 0 (absent) entered into the same menu.

The altitude and extent of aquifers were determined by approximating a continuous upper and lower surface using the layer altitudes defined at each well during the previous step. A continuous surface was fit to the layer altitude data at each well using an ordinary two-dimensional kriging utility in ArcInfo. The set of surfaces became the source of layer-elevation data used in MODFLOW-96 to represent the aquifers and confining unit conceptualized in the hydrostratigraphic framework. After creating the layer-surface elevations, the aerial extent of aquifer material in each layer was determined. 


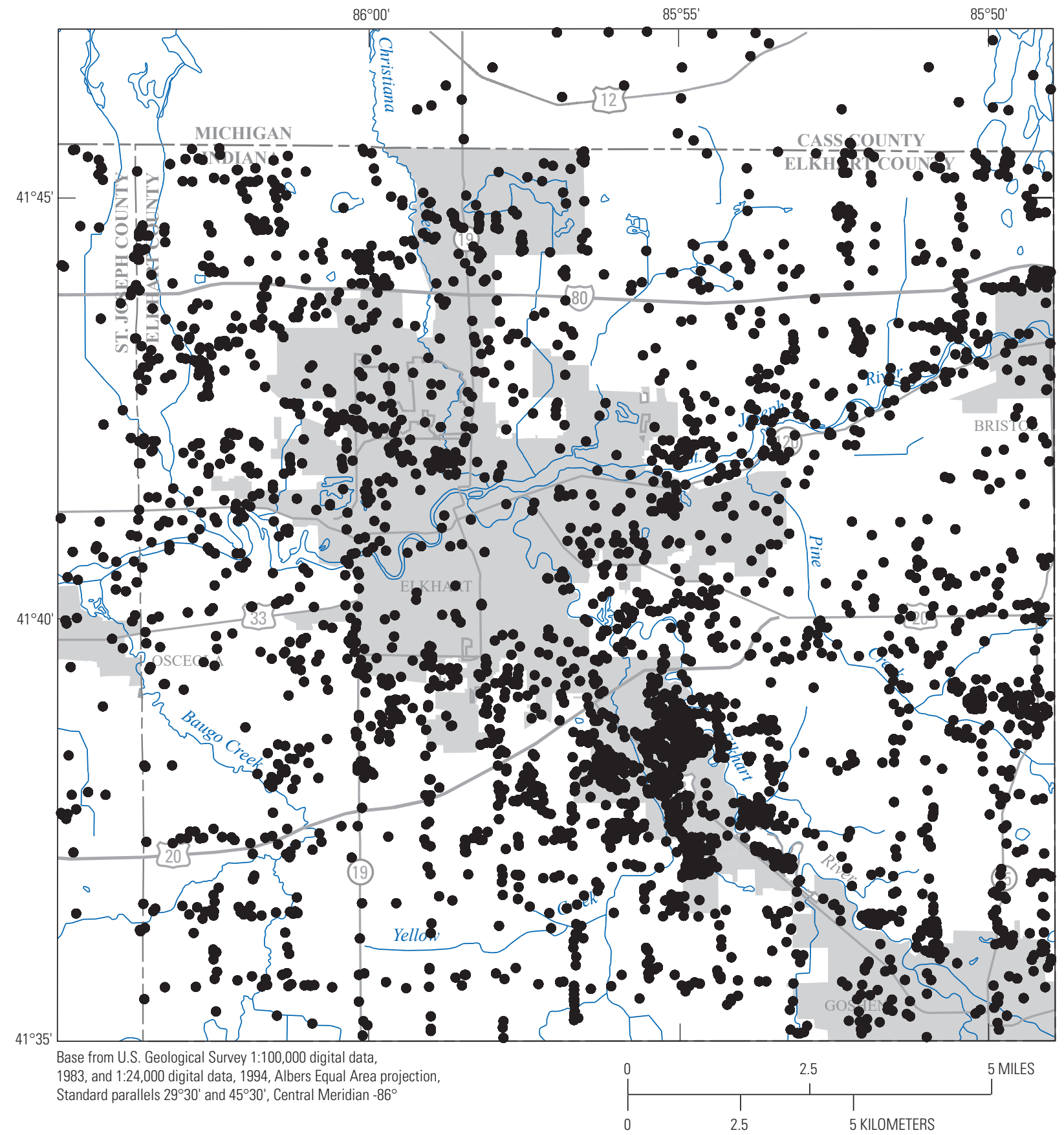

EXPLANATION

Incorporated urban and developed areas

- Location of water-well driller's log used

to construct Environmental Visualization

System framework

Figure 4. Locations of drillers' well records used to construct the objective groundwater model within the study area, Elkhart County, Indiana. 
Table 1. Textural classification of geologic deposits used to define an aquifer or a confining unit in the Elkhart study area.

[USGS, U.S. Geological Survey; coarse grained, aquifer unit material; fine grained, nonaquifer or confining unit material]

\begin{tabular}{|c|c|c|}
\hline $\begin{array}{l}\text { Description of } \\
\text { geologic deposit }\end{array}$ & $\begin{array}{l}\text { Textural } \\
\text { classification } \\
\text { of geologic } \\
\text { deposits }\end{array}$ & $\begin{array}{l}\text { USGS Groundwater } \\
\text { Site Inventory (GWSI) } \\
\text { system lithology code } \\
\text { assigned from well- } \\
\text { drillers' records }\end{array}$ \\
\hline Boulders & Coarse grained & BLDR \\
\hline Boulders and sand & Coarse grained & BLSD \\
\hline Cobbles & Coarse grained & COBB \\
\hline Cobbles and sand & Coarse grained & COSD \\
\hline Gravel & Coarse grained & GRVL \\
\hline Outwash & Coarse grained & OTSH \\
\hline Rubble & Coarse grained & RBBL \\
\hline Sand & Coarse grained & SAND \\
\hline Sand and gravel & Coarse grained & SDGL \\
\hline Boulders, silt, and clay & Fine grained & BLSC \\
\hline Clay & Fine grained & CLAY \\
\hline Clay, some sand & Fine grained & CLSD \\
\hline Cobbles, silt, and clay & Fine grained & COSC \\
\hline Gravel and clay & Fine grained & GRCL \\
\hline Gravel, cemented & Fine grained & GRCM \\
\hline Gravel, sand, and silt & Fine grained & GRDS \\
\hline Gravel, silt, and clay & Fine grained & GRSC \\
\hline Hard pan & Fine grained & HRDP \\
\hline Loam & Fine grained & LOAM \\
\hline Loess & Fine grained & LOSS \\
\hline Marl & Fine grained & MARL \\
\hline Muck & Fine grained & MUCK \\
\hline Mud & Fine grained & MUD \\
\hline Overburden & Fine grained & OBDN \\
\hline Peat & Fine grained & PEAT \\
\hline Sand and clay & Fine grained & SDCL \\
\hline Sand and silt & Fine grained & SDST \\
\hline Sand, gravel, and clay & Fine grained & SGVC \\
\hline Sand, some clay & Fine grained & SNCL \\
\hline Silt & Fine grained & SILT \\
\hline Silt and clay & Fine grained & STCL \\
\hline Soil & Fine grained & SOIL \\
\hline Till & Fine grained & TILL \\
\hline
\end{tabular}

An indicator kriging utility in ArcInfo used the presence (value of 1 ) or absence (value of 0 ) indicators recorded during individual well analysis to extrapolate the presence or absence of aquifer material within a layer. The kriged values of 1 and 0 generated a continuous distribution of probability values that were subsequently contoured. The 0.5 probability contour was identified as the boundary between aquifer and nonaquifer material (Johnson and Dreiss, 1989, p. 2509; Ritzi and others, 1994, p. 671). The presence and absence of the confining unit also was represented by the kriging values of 1 and 0 . If a well $\log$ record indicated that fine-grained deposits were present between the upper and lower aquifer, then the indicator kriged value was 1 . If the upper and lower aquifer were connected with no fine-grained deposits between the aquifers, then the indicator kriging value was 0 .

\section{Capabilities and Limitations of the Subjective Method}

The subjective method is distinguished from the objective method described in the next section by the following: (1) the inclusion of geohydrologic-based judgment of a hydrologist in developing the principal components of the hydrostratigraphic framework and eliminating data that indicated apparent geologic inconsistencies; (2) the use of indicator kriging to establish sharp lateral layer boundaries; and (3) the production of depth and thickness maps for individual layers.

The subjective method permitted the hydrologist to revise their hydrostratigraphic framework as familiarity with the well records and supporting geologic information increased. The groundwater model created with the subjective method may include fewer hydraulic parameters (data to define the hydraulic parameters are usually scarce) and, in that way, may contain fewer errors related to estimates of those parameters.

Limitations of the subjective method used in this study include the following:

1. a large amount of time is required for the hydrologist to evaluate each well record used in hydrostratigraphic framework construction;

2. only a subset of the available well-drillers' records are typically used;

3. the percent of well-drillers' records used decreases as the modeled area becomes larger (given similar time and budget constraints); and

4. depending on the application, oversimplification of the subjective groundwater model is possible.

As an example of the second limitation, only about 20 percent of the available well records for the study area were used to construct the subjective hydrostratigraphic framework and its related groundwater model. 


\section{Objective Method}

As computer solution speeds increase, the complexity that hydrologists can build into groundwater models and can visualize, also increases. The quantity of detail used in model construction is typically predetermined by the hydrologist according to the needs and applications of the modeler. The objective model used six values of horizontal and vertical hydraulic conductivity to quantify the lithologic descriptions in well records from the study area. Horizontal and vertical continuity of hydrogeologic units were considered simultaneously through use of three-dimensional kriging to interpolate values of hydraulic conductivity between data points (well records). All groundwater flow simulations were done using MODFLOW-2000 (Harbaugh and others, 2000) on a Windows computer.

\section{Data Preparation}

The standardized lithologic descriptions from GWSI (Mathey, 1989) that were assigned to geologic deposits from the well-record database for the subjective method were further assigned to six horizontal hydraulic conductivity codes (table 2). The codes represented the negative decadal logarithm of the horizontal hydraulic conductivity $\left(-\log _{10} \mathrm{~K}\right.$, in centimeters per second) for that material; horizontal hydraulic conductivity values in Fetter (1994, p. 98) were used for this study. For example, if the horizontal hydraulic conductivity assigned to a geologic material is $10^{-2}$ centimeters per second, then the horizontal hydraulic conductivity code is 2 . Similar methods have been used by Johnson and Dreiss (1989), Ritzi and others (1994, 1995), and Zhang and Brusseau (1998) to reduce sediment texture descriptions to order of magnitude values of horizontal hydraulic conductivity. Horizontal hydraulic conductivity codes were assigned to well-drillers' records at 5-ft intervals of depth and at the interface of any geologic material change described in the well records as illustrated in the example well log record of figure 5. The reformulated dataset of horizontal hydraulic conductivity codes was used as input to the commercial software package EVS to construct the objective hydrostratigraphic framework and the related groundwater model.

\section{Development of Objective Hydrostratigraphic Framework}

For the objective hydrostratigraphic framework, the commercial software EVS was used to create a continuous distribution of hydrostratigraphy of the study area. The EVS is an environmental data-visualization system with a module-based graphical user interface designed to fit many applications. The EVS software used for this study was run on an IBM personal computer platform in a Microsoft Windows 2000 desktop environment using a computer equipped with an Athlon AMD central processing unit operating at 1.4 gigahertz.

Execution time to create a hydrostratigraphic framework from the Elkhart County dataset typically ranged from 60 to 120 minutes. The objective method was fully automated with the exception that a hydrologist, familiar with well-record data, selected the kriging parameters that were used to identify the sharpness of boundaries between hydrostratigraphic units and that were used to develop the horizontal hydraulic conductivity distributions for the groundwater model.

Three-dimensional kriging was used in EVS to produce a continuous distribution of the horizontal hydraulic conductivity codes. The continuous distributions were trimmed to fit the spatial boundaries of the study area, and color-range approximations were assigned to horizontal hydraulic conductivity codes for visualization purposes. The uppermost boundary for the objective hydrostratigraphic framework was land-surface altitude estimated from digital elevation models. The lowermost boundary for the framework was the bedrock-surface elevation as interpreted from well-drillers' records.

The EVS uses an internal expert system to characterize the input dataset and build multidimensional variograms (C Tech, 2008). The expert system evaluates the frequency

Table 2. Well record descriptors and horizontal hydraulic conductivities used in objective model.

[USGS, U.S. Geological Survey; cm/s, centimeters per second]

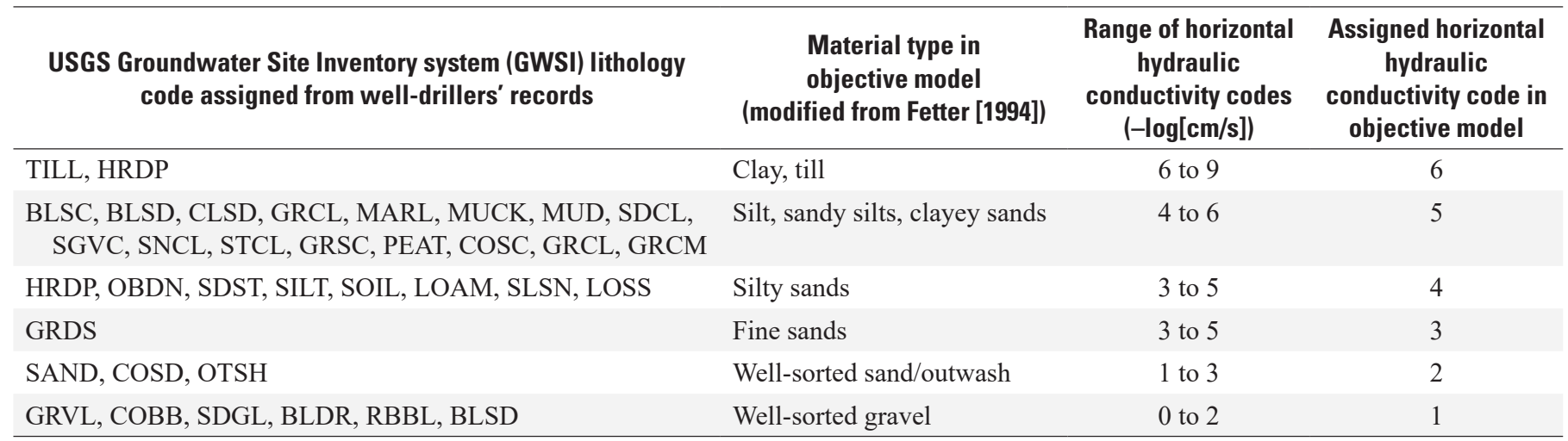




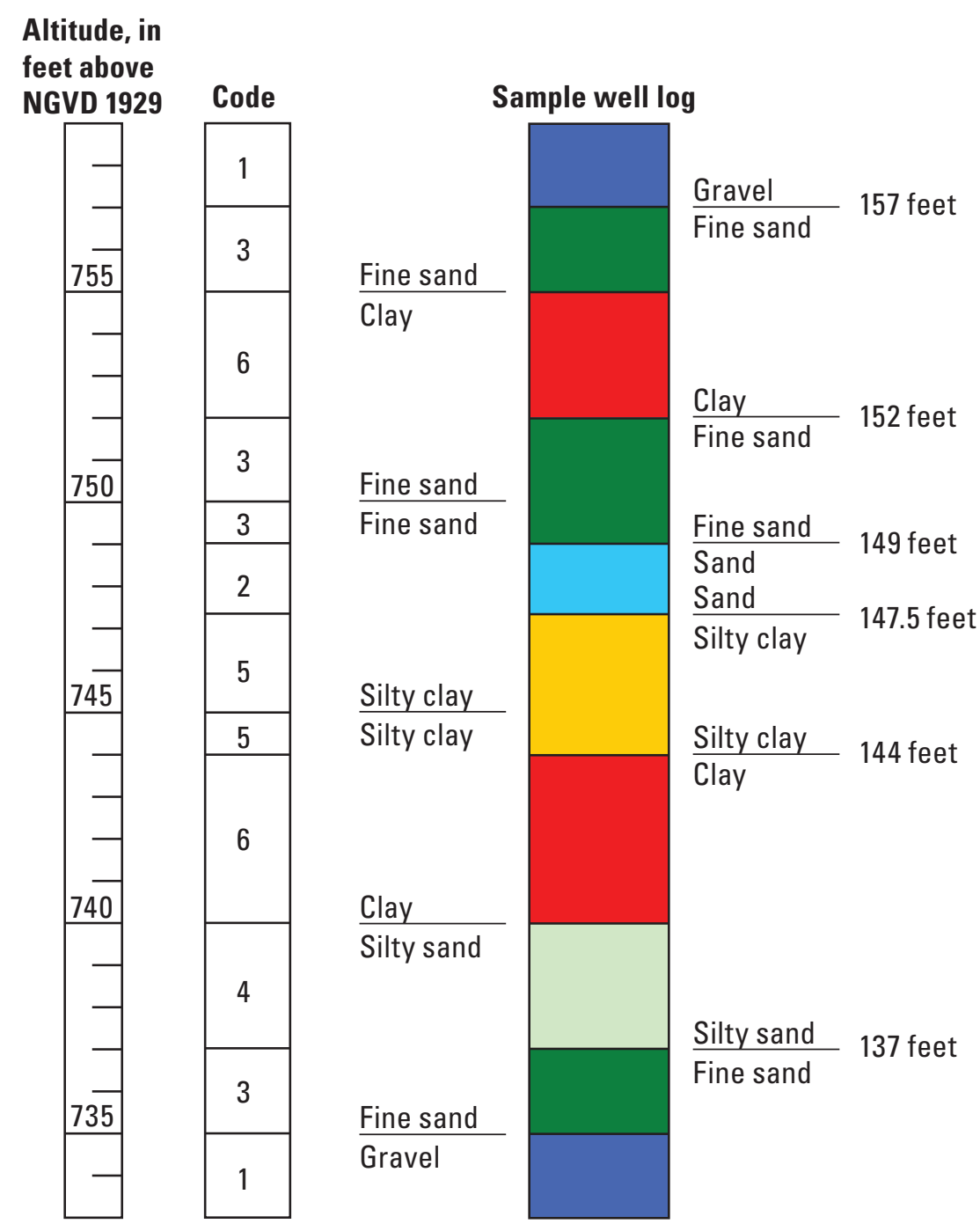

\section{EXPLANATION}

\begin{tabular}{|l|l}
\hline & Clay \\
\hline \hline & Silty clay \\
\hline \hline & Silty sand \\
\hline & Fine sand \\
\hline & Sand \\
\hline$\square$ & Gravel
\end{tabular}

Figure 5. Example assignment of horizontal hydraulic conductivity code to a well log. Horizontal hydraulic conductivity codes are assigned at 5 -foot intervals (center left) and at boundaries between two lithologies (center right). 
and distribution of the input data and creates a variogram that minimizes differences between measured data and values estimated by the kriging. Some kriging parameters (including the sill, minimum range, and maximum range) can be specified by the user. The variogram nugget that represents the variability of data at very small distances from each point (Matzke and others, 2010) was set at zero for this study. The zero nugget value means kriged interpolations at a point of known lithology will always result in the assumed horizontal hydraulic conductivity for that lithology. Parameters determined for the multidimensional variogram were then used to krige the datasets into a three-dimensional distribution of horizontal hydraulic conductivity for the objective groundwater model of the study area. Parameters, which included the horizontal to vertical bias and the variogram sill and range, were varied on a trial and error basis, and the distribution was recalculated until several working distributions were developed. The sill can be understood as the largest variability of a property between pairs of wells (data points) and the range is the approximate distance between data points at which the largest variability of a property is reached (Matzke and others, 2010). A geologist author of this report (Brown) then reviewed the working distributions and selected the most plausible distribution of deposits based on prior surficial geologic mapping of the Elkhart study area (Indiana Geological Survey, 2009). Final parameter values for the conductivity distributions in the objective hydrostratigraphic framework and the related groundwater model are listed in table 3 .

\section{Capabilities and Limitations of the Objective Method}

Data entry for creation of the groundwater-flow model based on the objective hydrostratigraphic framework was facilitated by EVS; digital well-drillers' records and digital elevation models were read into the program as tab-delimited American Standard Code for Information Interchange (ASCII) files. Input file formats were simple to develop and data processing time before importing well records into EVS was brief. Kriging parameters can be quickly adjusted in EVS; however, computational times limited the number of different sets of parameters that were evaluated.

The EVS module used to compute horizontal hydraulic conductivity values is designed for the simulation of continuous data, such as chemical concentrations. The computation process creates a continuum, or gradually changing values

Table 3. Kriging parameters estimated by Environmental Visualization System (EVS) software package for the study area.

\begin{tabular}{lc}
\hline EVS parameters & Elkhart County, Indiana \\
\hline Sill & 0.91 \\
Range (meters) & 1,350 \\
Anisotropy & 100 \\
\hline
\end{tabular}

ranging from the minimum to the maximum of the observation dataset. However, actual distributions of geologic deposits and their horizontal hydraulic conductivities typically change abruptly from low to high values at the interface between fine- and coarse-grained deposits (clay overlain by gravel, for example). The parameter estimation process in the groundwater-flow model MODFLOW-2000 (Harbaugh and others, 2000; Hill, 1998) was used to adjust the horizontal hydraulic conductivities and revise this continuum of horizontal hydraulic conductivities into more representative abrupt changes in hydraulic conductivity.

The EVS software provides enhanced data-visualization graphical capability, such as the ability to depict horizontal hydraulic-conductivity distributions as three-dimensional block diagrams (fig. 6). The distribution can be viewed from different angles or as areas of specific horizontal hydraulic conductivity (only clay areas, for example) that are isolated from other data and displayed to help understand the complexities of the distribution of different units within the objective hydrostratigraphic framework. Additional visualizations include block slices, cross sections, two- and three-dimensional isosurfaces, and the visualization of point data.

The continuous distribution of horizontal hydraulic conductivity output by EVS was discretized into values at intervals that corresponded to the model-grid cells of the original Elkhart groundwater-flow model (Arihood and Cohen, 1998). Discretized values of horizontal hydraulic conductivity were exported from the EVS software package as ASCII text files. These text files were then further modified using AML programs to format the files to be read by MODFLOW-2000.

Visual comparison of errors between measured data and kriged values was done in EVS using modules that simultaneously posted both values in the same view. One source of error could result from the effect of the zero nugget assumption. Although a zero nugget assumption that exactly represents the lithology record at each well record is conceptually sound when all classifications are accurate, the disadvantage of a zero nugget assumption is that an anomalous classification of lithology in an individual well record can never be overridden by geologic classifications indicated by nearby lithologies. For example, if 10 nearby lithologic classifications indicate a continuous sand deposit and 1 classification indicates a clay deposit, then the 10 sand lithologies provide evidence that the clay lithology may represent an anomalous deposit or possibly an erroneous classification. Application of a zero nugget assumption will preserve anomalous heterogeneities in interpolations of horizontal hydraulic conductivity properties within the model. Because of the possibility of anomalous data and occasional errors in crowd-sourced lithologic classifications, Proce and others (2004) suggested using the complete set of well-drillers' records with an understanding of the distribution and nature of possible errors within the data, and if well logs were to be eliminated, that the distribution would be recalculated using only acceptable well logs. Anomalous well logs were not eliminated because of the time required to find every anomalous $\log$. 


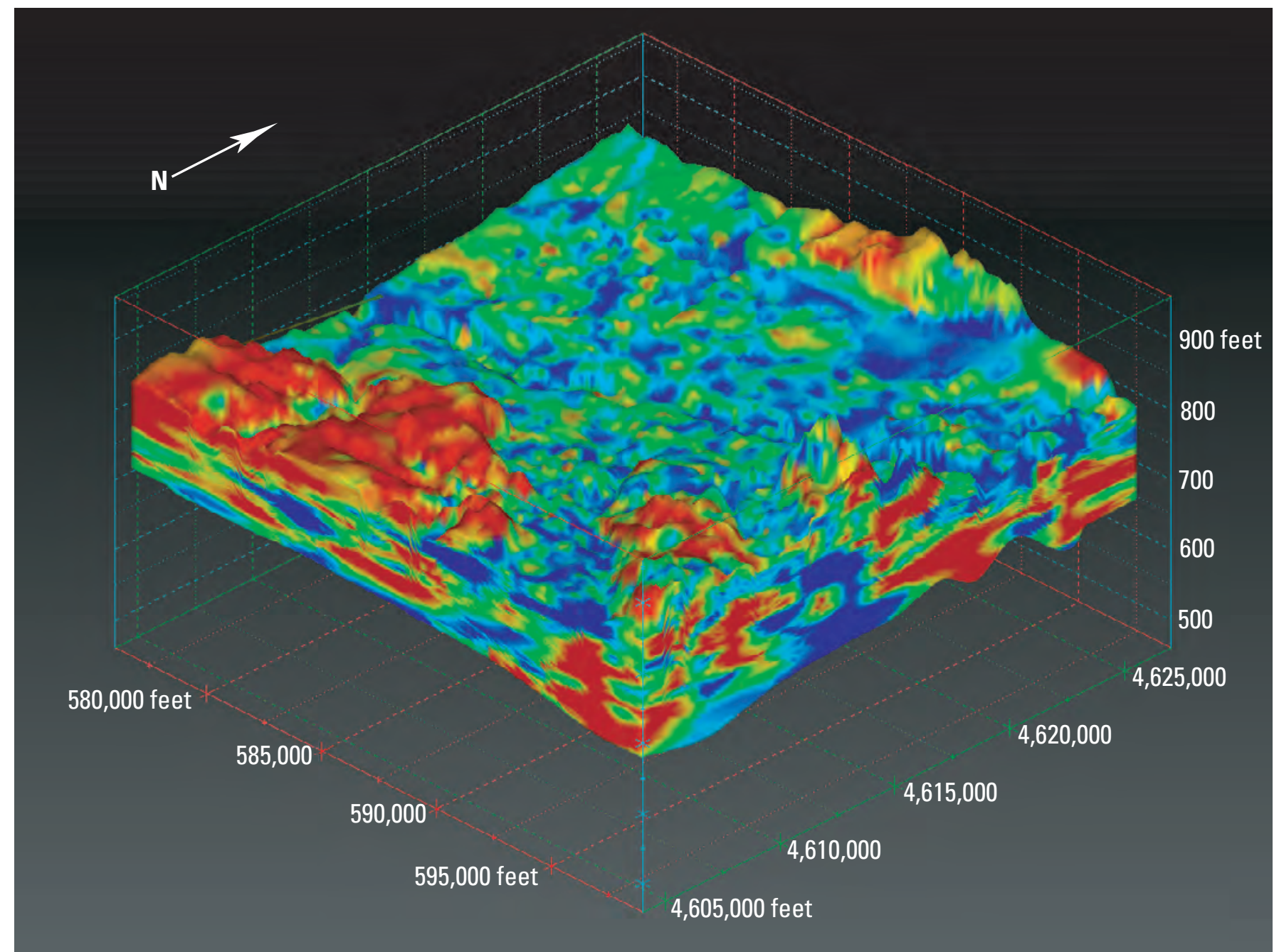

Base from U.S. Geological Survey digital data 1:100,000 1983. Albers Equal Area projection Standard parallels $29^{\circ} 30^{\prime}$ and $45^{\circ} 30^{\prime}$,

Central meridian $-86^{\circ}$, North American Datum of 1983

\section{EXPLANATION}

Vertical exaggeration times 20 , viewing perspective is from southeast at 30 degrees to land surface

\section{Geologic material and hydraulic conductivity codes}

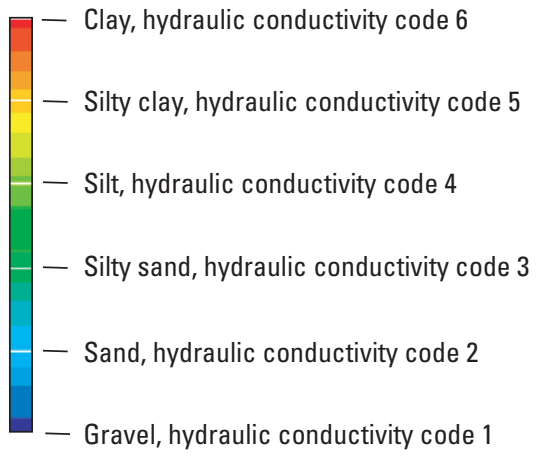

Figure 6. Three-dimensional representation of the distribution of geologic deposits and horizontal hydraulic conductivity codes for the study area in Elkhart County, Indiana. 


\section{Comparison of Representations of Glacial Geology}

Subjective and objective groundwater models representing their corresponding hydrostratigraphic framework of the glacial geology were constructed for the Elkhart study area in the St. Joseph River Basin. In this section, the groundwater models are illustrated for the study area and then compared with aspects of the physical descriptions of geology.

The groundwater model for the subjective method is mostly consistent with the geologic description presented previously, except for the depiction of a confining unit. The groundwater model for the subjective method has been previously illustrated by Arihood and Cohen (1998) by a surface geology map (fig. 3), a diagrammatic section (fig. 7), transmissivity maps of the upper and lower aquifers (figs. 8 and 9, respectively), and a confining unit thickness map (fig. 10).

The subjective hydrostratigraphic framework and related groundwater model represent the overall glacial geologic characteristics of the study area. The surface geology map (fig. 3) depicts a broad area of outwash. The diagrammatic section (fig. 7) shows two aquifers separated by a single, nearly continuous fine-grained confining unit. A hydrogeologic description of the St. Joseph River outwash plain by Fleming and others (1995) similarly describes large deposits of aerially continuous sand and gravel but indicates that fine-grained deposits may be present as discontinuous beds within the sand and gravel. The continuous aquifer and confining unit associated with the subjective groundwater model is consistent with abrupt vertical and lateral contrasts in sediment properties. The transmissivity maps (figs. 8 and 9) indirectly show aquifer thickness because transmissivity equals the product of saturated aquifer thickness multiplied by the horizontal hydraulic conductivity of the aquifer, and the horizontal hydraulic conductivity used to represent the upper and lower aquifer units does not vary through most of the Elkhart study area (Arihood and Cohen, 1998, p. 25). The transmissivity maps show generally continuous aquifers that increase in thickness from south to north with the upper aquifer increasing the most. The upper aquifer (fig. 8) is present in small amounts and the lower aquifer (fig. 9) is sometimes absent in the subjective groundwater model south of the St. Joseph River, similar to the description of sand and gravel deposits described in the glacial geology section of this report.

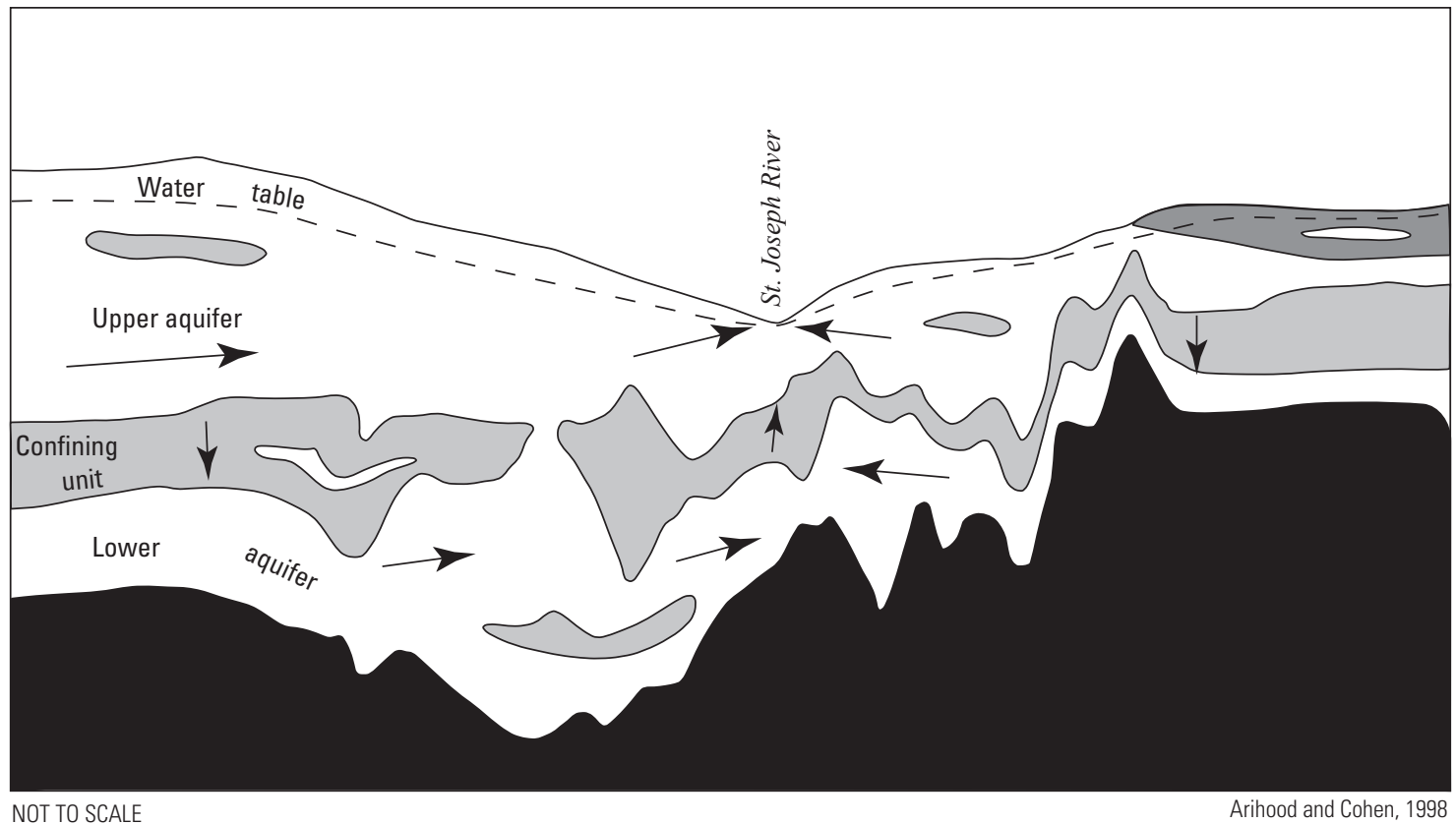

\section{EXPLANATION}

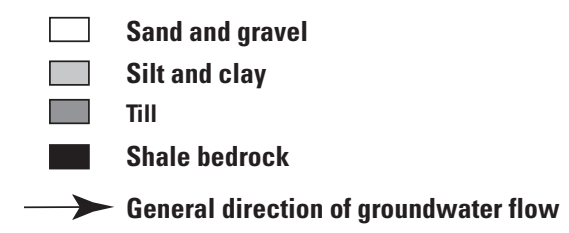

Figure 7. Diagrammatic section showing major hydrostratigraphic features and assumed direction of groundwater flow for the subjective method. 


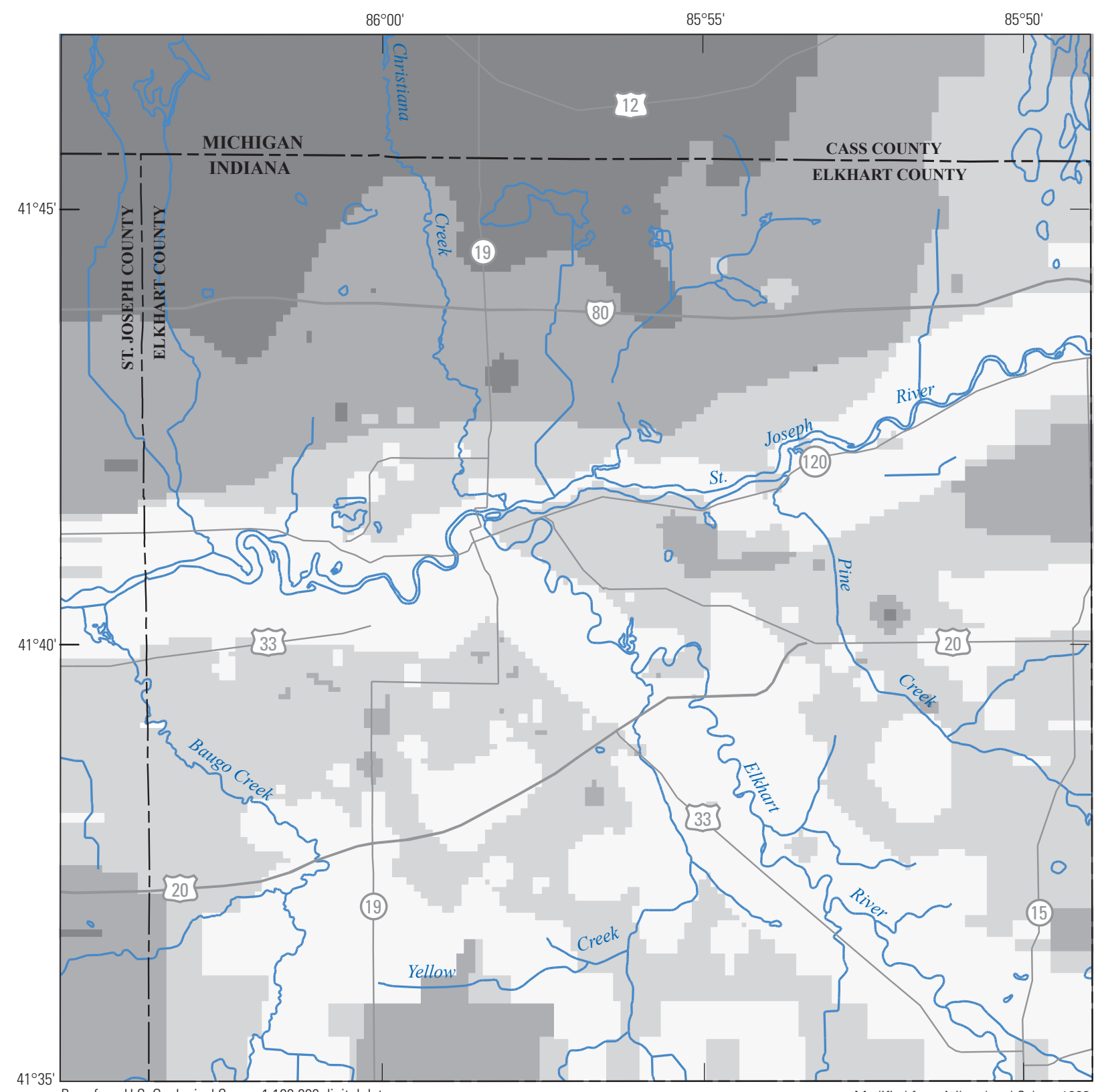

Base from U.S. Geological Survey 1:100,000 digital data,

1983, and 1:24,000 digital data, 1994, Albers Equal Area projection,

Standard parallels $29^{\circ} 30^{\prime}$ and $45^{\circ} 30^{\prime}$, Central Meridian $-86^{\circ}$

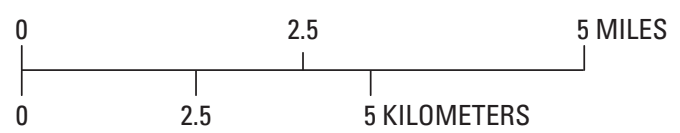

\section{EXPLANATION}

\section{Values of transmissivity}

Less than 7,000 feet squared per day

Between 7,000 and less than 15,000 feet squared per day

Between 15,000 and less than 25,000 feet squared per day

25,000 feet squared per day and greater

Figure 8. Transmissivity for the upper aquifer in the Elkhart study area reflecting thickness of sand and gravel for the groundwater model of the subjective method. 


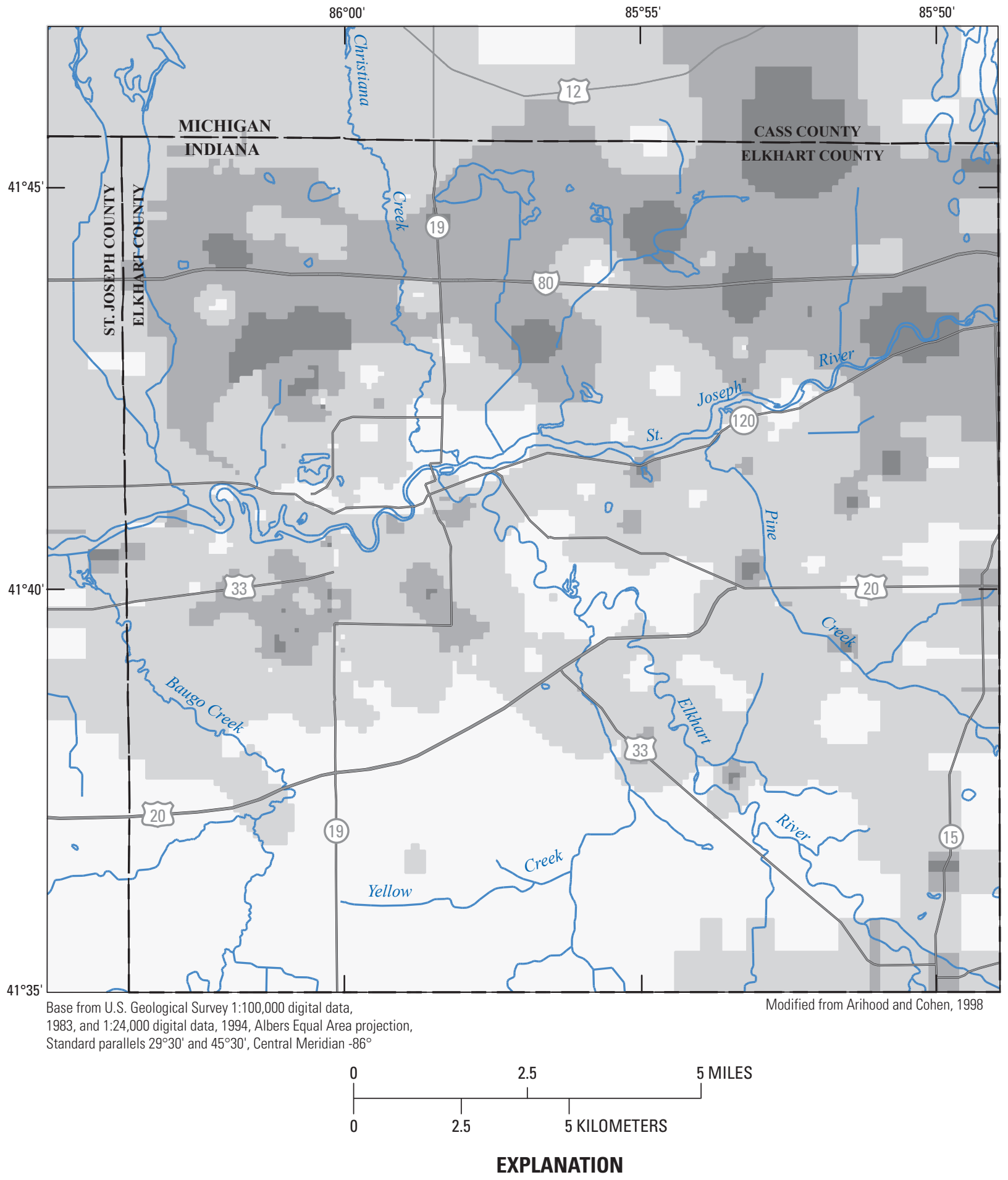

Values of transmissivity

Less than 7,000 feet squared per day

Between 7,000 and less than 15,000 feet squared per day

Between 15,000 and less than 25,000 feet squared per day

25,000 feet squared per day and greater

Figure 9. Transmissivity for the lower aquifer in the Elkhart study area reflecting thickness of sand and gravel for the groundwater model of the subjective method. 


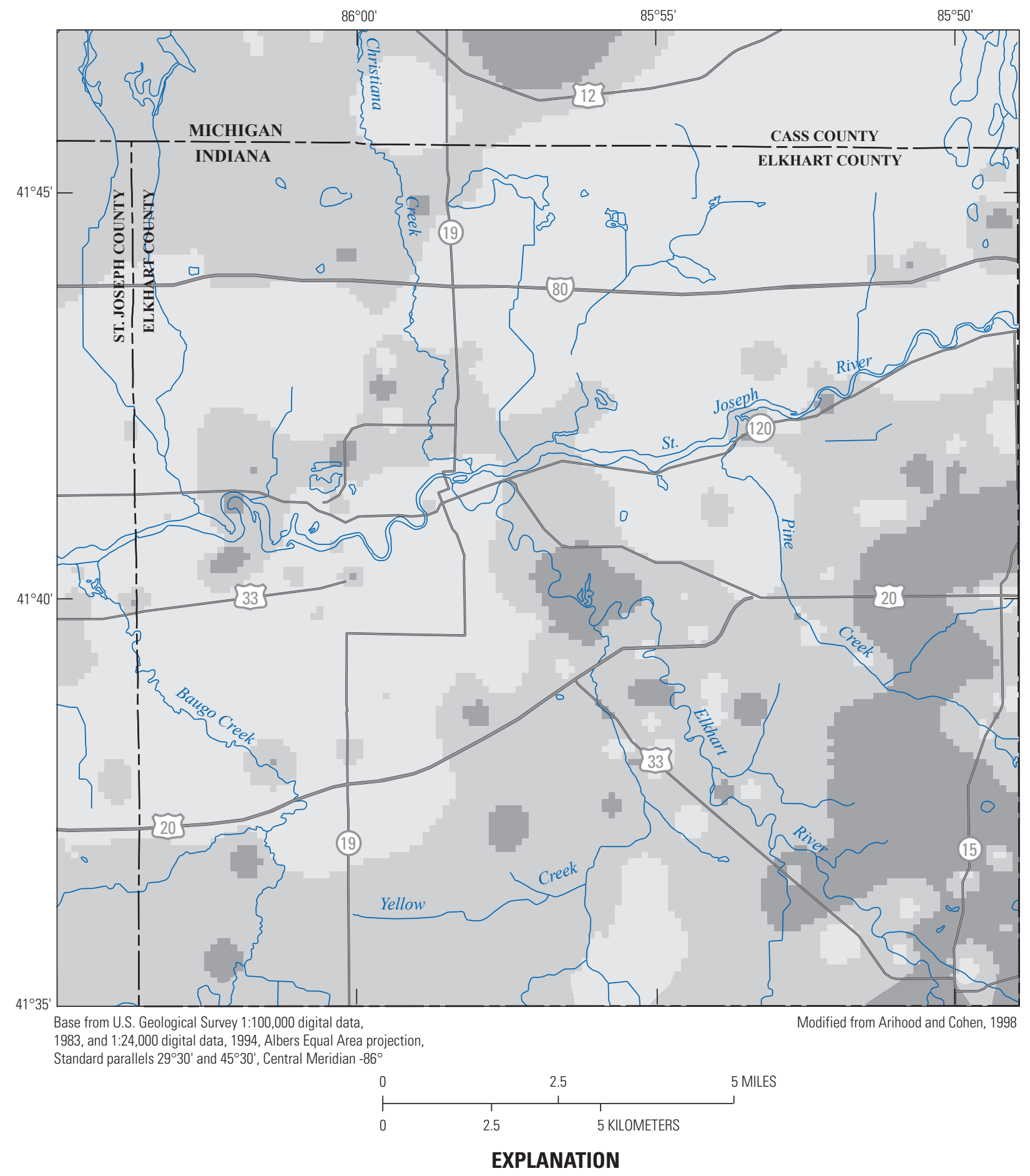

Thickness of confining unit

Between 1 and 25 feet

Between greater than 25 and 50 feet

Between greater than 50 and 177 feet

Figure 10. Thickness of the confining unit in the Elkhart study area as depicted by the groundwater model for the subjective method. 
The subjective method classified a single, nearly continuous confining unit between the upper and lower aquifers (fig. 10). Geologic descriptions of this area and nearby areas such as those by Russell and Leverett (1908) and of a nearby area in Michigan by Stone (2001) describe multiple ice margins advancing and retreating, producing complex and overlapping sequences of deposits. The glaciofluvial deltaic deposits described as the source of the outwash and alluvium near the St. Joseph River would likely create multiple layers of fine-grained deposits and not a single confining unit. The subjective groundwater model assumed that confining units at multiple altitudes could be represented as a single, continuous, hydraulically interconnected unit with a single value for vertical hydraulic conductivity for groundwater-flow modeling purposes.

The groundwater model yielded from the objective method is generally consistent with the previous geologic description, but differs from the model for the subjective method in the continuity of confining units. Surface geology represented by the groundwater model for the objective method is illustrated in the three-dimensional diagram shown in figure 6 . The basic features are the same as those shown in figure 6-a wide area of coarse-grained deposits in the northern part of the study area and fine-grained deposits in the southwestern and southeastern part. A mixture of silty sand and sand and gravel is indicated near land surface throughout the middle part of figure 6; this is at the top of an outwash plain described for the study area (Fleming and others, 1995). Silty sand, represented in dark green (fig. 6), is considered aquifer material and visibly composes a part of the outwash volume in the groundwater model of the objective method. The silty sand is considered part of the outwash because the sand was deposited by glacial meltwater. In the subjective method, all aquifer material has a uniform horizontal hydraulic conductivity representative of sand and gravel.

Aquifer deposits are present beneath the till on the south side of a cross section through the groundwater model for the objective method, and the aquifer material can be present at multiple altitudes within the till (fig. 11). Glacial till is represented as clay and silty clay deposits in the upper part of glacial deposits in the southern part of the Elkhart study area (fig. 11). Large thicknesses of sand and gravel deposits are present north of the till deposits and in the central (topographically lower) and northern (topographically higher) parts of the section. This distribution of deposits is similar to the geologic description and the groundwater model for the subjective method. The confining unit, represented by yellow and red in the cross section (fig. 11), is discontinuous, which is in contrast to the continuous confining unit indicated in the subjective groundwater model. The geologic description generally indicates that fine-grained deposits within the outwash are discontinuous. These characteristics of aquifer occurrence are compatible with the overall hydrogeologic description (Fleming and others, 1995).

\section{Comparison of Model Designs}

The subjective and objective groundwater-flow models use the same horizontal discretization and type of internal and external boundary conditions, but the models use different methods to estimate recharge and represent vertical variation in the hydrostratigraphy. Model design for the subjective model is described in detail by Arihood and Cohen (1998), but important features of the subjective model are repeated here for comparison purposes.

The study area was discretized into small areas of uniform hydrogeologic properties. The model grid for both subjective and objective models is a rectangular block-centered grid network that covers a 190 square mile area of Elkhart County (fig. 12). The grid (13.7 by 13.9 miles) was composed of 13,224 blocks that ranged in size from 500 by $500 \mathrm{ft}$ in the central part of the modeled area to 3,000 by $3,000 \mathrm{ft}$ at the corners.

River and drain nodes (Harbaugh and others, 2000) were used in the subjective and objective models to represent local streams (fig. 12). A total of 790 river nodes were used to simulate the St. Joseph and Elkhart Rivers and Christiana and Baugo Creeks (fig. 12). River nodes were used to represent large streams that discharge groundwater to surface water and that can supply appreciable recharge to the groundwater-flow system when the water table declines below the bottom of the stream. A total of 736 drain nodes were used to simulate the remaining smaller streams. Drain nodes receive groundwater discharge but do not recharge the groundwater system. Drain nodes represent small streams that cease to flow when the water table declines below the bottom of the stream.

Boundary conditions in the subjective and objective groundwater models were selected so the type and location of the boundary would have a minimal effect on the result of simulated pumping; therefore, boundaries were placed far from major pumping centers. Constant-head nodes were placed to represent model boundaries on all four sides of each model layer (fig. 12). Constant-head nodes, however, were not added if a river or drain node were at the edge of the model. Water levels used for the boundary nodes and for all initial water levels at the other model nodes were estimated by regression equations relating ground surface to aquifer water levels (Arihood and Cohen, 1998, p. 22). Separate regression equations were developed for the upper and lower aquifers. Generally, constant-head nodes are useful to simulate the flow of water across the edge of the model (in or out of the model) and to help stabilize the iterative solution process. Fluxes from the constant head nodes were constrained by measurements of streamflow gain throughout the modeled area. Arihood and Cohen $(1998$, p. 40, 44) demonstrated that the constant-head boundaries did not affect model response in the center of the model where the major pumping centers are located. A free surface, or water table boundary was simulated at the top of the active groundwater flow system. A no-flow boundary was assumed below the bottom layer of the model to simulate the low-permeability shale at the base of the glacial deposits. 


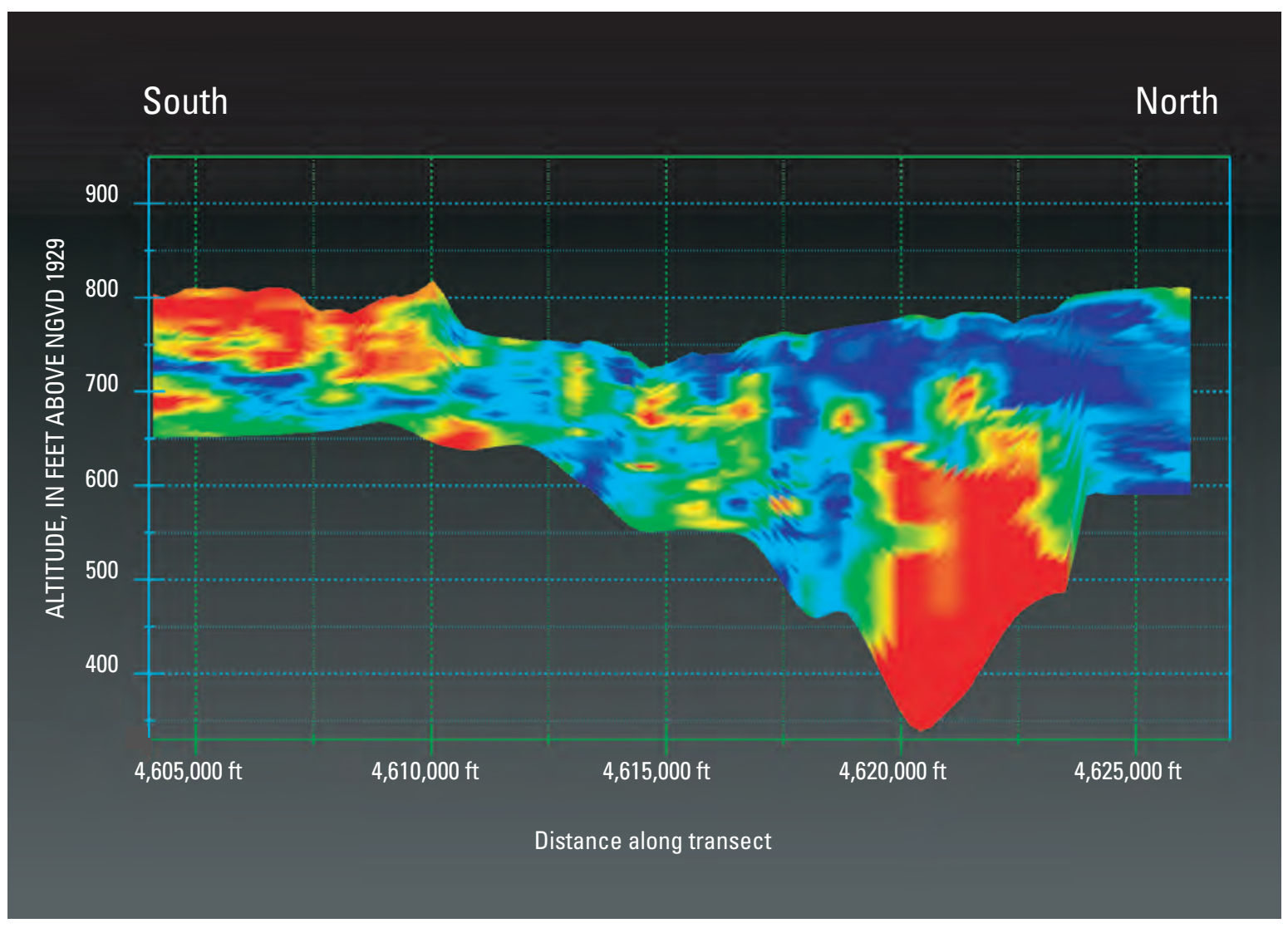

Vertical exaggeration is times 20

\section{EXPLANATION}

\section{Geologic material and hydraulic conductivity codes}

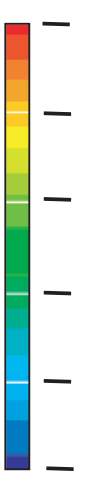

Clay, hydraulic conductivity code 6

- Silty clay, hydraulic conductivity code 5

- Silt, hydraulic conductivity code 4

- Silty sand, hydraulic conductivity code 3

- Sand, hydraulic conductivity code 2

- Gravel, hydraulic conductivity code 1

Figure 11. Geologic section along column 29 of the groundwater-flow model showing distribution of deposits derived from the groundwater model for the objective method. 


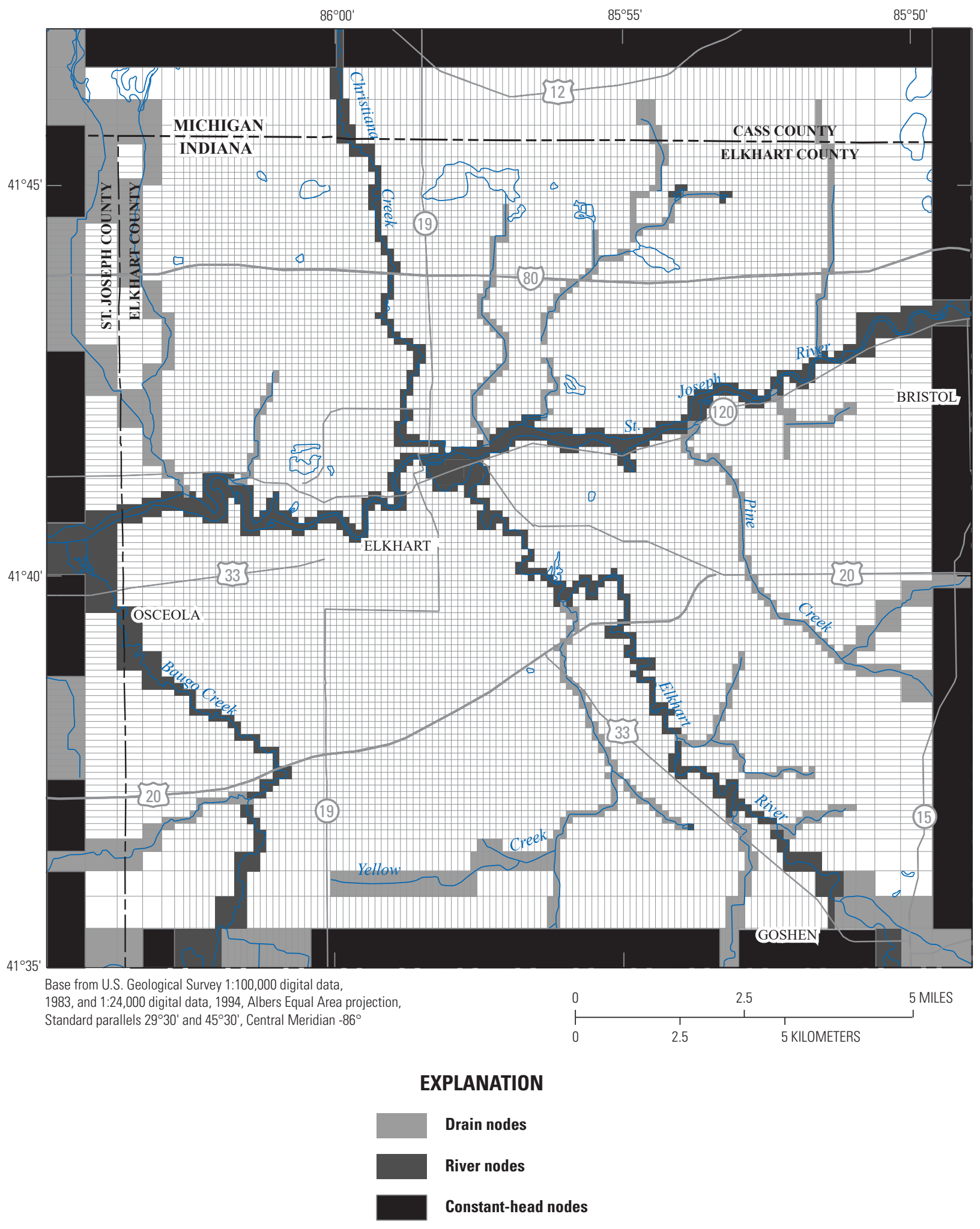

Figure 12. Model grid, boundary conditions, and types of stream nodes used in the simulation of groundwater flow in the Elkhart County, Indiana, study area. 
Recharge was applied to the subjective and objective groundwater models at similar vertical positions, but the rates of recharge varied. Recharge was applied to the uppermost active model layer in both models. The initial value for recharge rate was based on surface geology in the subjective model and was based on geologic descriptions from the welldriller records for the objective model. Most of the surface geology consisted of glacial-fluvial deposits and till, and the corresponding recharge rates for the two deposits were 16 and 4 inches per year, respectively on two prior groundwater simulations of the study area (Imbrigiotta and Martin, 1981, p. 44; Arihood and Cohen, 1998, p. 23). Well-log lithology records at land surface were grouped into the following four classes: clay, sand, sand and gravel, and gravel. Each class of lithology initially received an individual recharge rate that ranged from 4 to 16 inches per year, based on the values used in the previous cited simulations (table 4).

Horizontal hydraulic conductivity in the subjective model was defined on the basis of position relative to the St. Joseph River as well as model layer. In the upper aquifer, horizontal hydraulic conductivity was $170 \mathrm{ft} / \mathrm{d}$ near the river and $370 \mathrm{ft} / \mathrm{d}$ away from the river. In the lower aquifer, horizontal hydraulic conductivity was $370 \mathrm{ft} / \mathrm{d}$. Areas in the upper aquifer that were composed of fine-grained deposits were assigned

Table 4. Model parameters used for the objective model and their initial values.

$[\mathrm{ft} / \mathrm{d}$, foot per day; in/yr, inch per year]

\begin{tabular}{|c|c|c|}
\hline $\begin{array}{l}\text { Parameter } \\
\text { name }\end{array}$ & Model component represented & Initial parameter value ${ }^{1}$ \\
\hline K1 & Horizontal hydraulic conductivity for cells assigned to gravel & $400 \mathrm{ft} / \mathrm{d}$ \\
\hline $\mathrm{K} 2$ & Horizontal hydraulic conductivity for cells assigned to sand and gravel & $150 \mathrm{ft} / \mathrm{d}$ \\
\hline $\mathrm{K} 3$ & Horizontal hydraulic conductivity for cells assigned to sand & $20 \mathrm{ft} / \mathrm{d}$ \\
\hline K4 & Horizontal hydraulic conductivity for cells assigned to silty sand & $1 \mathrm{ft} / \mathrm{d}$ \\
\hline K5 & Horizontal hydraulic conductivity for cells assigned to sandy silt and silt & $0.05 \mathrm{ft} / \mathrm{d}$ \\
\hline K6 & Horizontal hydraulic conductivity for cells assigned to clay & $0.001 \mathrm{ft} / \mathrm{d}$ \\
\hline KV1 & Vertical hydraulic conductivity for cells assigned to gravel & $80 \mathrm{ft} / \mathrm{d}$ \\
\hline KV2 & Vertical hydraulic conductivity for cells assigned to sand and gravel & $30 \mathrm{ft} / \mathrm{d}$ \\
\hline KV3 & Vertical hydraulic conductivity for cells assigned to sand & $4 \mathrm{ft} / \mathrm{d}$ \\
\hline KV4 & Vertical hydraulic conductivity for cells assigned to silty sand & $1 \mathrm{ft} / \mathrm{d}$ \\
\hline KV5 & Vertical hydraulic conductivity for cells assigned to sandy silt and silt & $0.0005 \mathrm{ft} / \mathrm{d}$ \\
\hline KV6 & Vertical hydraulic conductivity for cells assigned to clay & $0.00001 \mathrm{ft} / \mathrm{d}$ \\
\hline D1 & Hydraulic conductivity of drain cells corresponding to $1.0 \mathrm{ft} / \mathrm{d}$ & $1.0 \mathrm{ft} / \mathrm{d}$ \\
\hline D005 & Hydraulic conductivity of drain cells corresponding to $0.05 \mathrm{ft} / \mathrm{d}$ & $0.05 \mathrm{ft} / \mathrm{d}$ \\
\hline $\mathrm{R} 1$ & Hydraulic conductivity of river cells corresponding to $1.0 \mathrm{ft} / \mathrm{d}$ & $1.0 \mathrm{ft} / \mathrm{d}$ \\
\hline R001 & Hydraulic conductivity of river cells corresponding to $0.01 \mathrm{ft} / \mathrm{d}$ & $0.01 \mathrm{ft} / \mathrm{d}$ \\
\hline R01 & Hydraulic conductivity of river cells corresponding to $0.1 \mathrm{ft} / \mathrm{d}$ & $0.1 \mathrm{ft} / \mathrm{d}$ \\
\hline R05 & Hydraulic conductivity of river cells corresponding to $0.5 \mathrm{ft} / \mathrm{d}$ & $0.5 \mathrm{ft} / \mathrm{d}$ \\
\hline R005 & Hydraulic conductivity of river cells corresponding to $0.05 \mathrm{ft} / \mathrm{d}$ & $0.05 \mathrm{ft} / \mathrm{d}$ \\
\hline $\mathrm{R} 50$ & Hydraulic conductivity of river cells corresponding to $50 \mathrm{ft} / \mathrm{d}$ & $50 \mathrm{ft} / \mathrm{d}$ \\
\hline $\mathrm{RECH} 2$ & Recharge rate to cells assigned to clay & $4 \mathrm{in} / \mathrm{yr}$ \\
\hline RECH11 & Recharge rate to cells assigned to sand & $11 \mathrm{in} / \mathrm{yr}$ \\
\hline RECH14 & Recharge rate to cells assigned to sand and gravel & $14 \mathrm{in} / \mathrm{yr}$ \\
\hline RECH16 & Recharge rate to cells assigned to gravel & $16 \mathrm{in} / \mathrm{yr}$ \\
\hline
\end{tabular}

${ }^{1}$ Initial horizontal hydraulic conductivity values are estimated from Freeze and Cherry (1979). Initial hydraulic conductivity values of river and drain cells are from Arihood and Cohen (1998). 
a transmissivity of $20 \mathrm{ft} / \mathrm{d}$. In the objective method of model construction, textural differences and variations in glacial deposits were represented by six lithologies and six corresponding horizontal hydraulic conductivities.

The degree of vertical discretization varied greatly between the two models. The subjective model is made up of two model layers that simulate the upper and lower aquifers and an intervening vertical leakage layer that simulates the confining unit (fig. 13). The upper aquifer (layer 1) was simulated under water-table conditions in the northern two-thirds of the study area and under confined conditions in the southern one-third of the study area where till covers the aquifer. The lower aquifer (layer 2) was simulated under confined conditions with aerially variable transmissivity. In areas where the confining unit is absent, the thickness in the subjective model was represented as a 40-ft sand and gravel deposit between the centers of the upper and lower aquifers. Vertical leakage across the 40-ft sand and gravel deposit was calculated on the basis of a vertical hydraulic conductivity of $80 \mathrm{ft} / \mathrm{d}$. The $80 \mathrm{ft} / \mathrm{d}$ value of vertical hydraulic conductivity was derived by assuming that the vertical hydraulic conductivity of sand and gravel is one-fifth the horizontal hydraulic conductivity of $400 \mathrm{ft} / \mathrm{d}$ assumed by Imbrigiotta and Martin (1981). The vertical distance of $40 \mathrm{ft}$ between the centers of the aquifers was chosen as a dimension that was typical within the subjective model. The objective model is made up of 30 model layers that are $20.33 \mathrm{ft}$ thick.

Seven major water withdrawal facilities were represented in the subjective and objective models, including three fields with multiple production wells. Water use data from 1979 were used for model calibration, and data from 1993 for model simulations. Water withdrawals at these sites were more than 100,000 gallons per day and totaled $19.7 \mathrm{ft}^{3} / \mathrm{s}$ in 1993 (fig. 14). Domestic withdrawals were not simulated because of the low withdrawal rates and diffuse pattern of withdrawals.

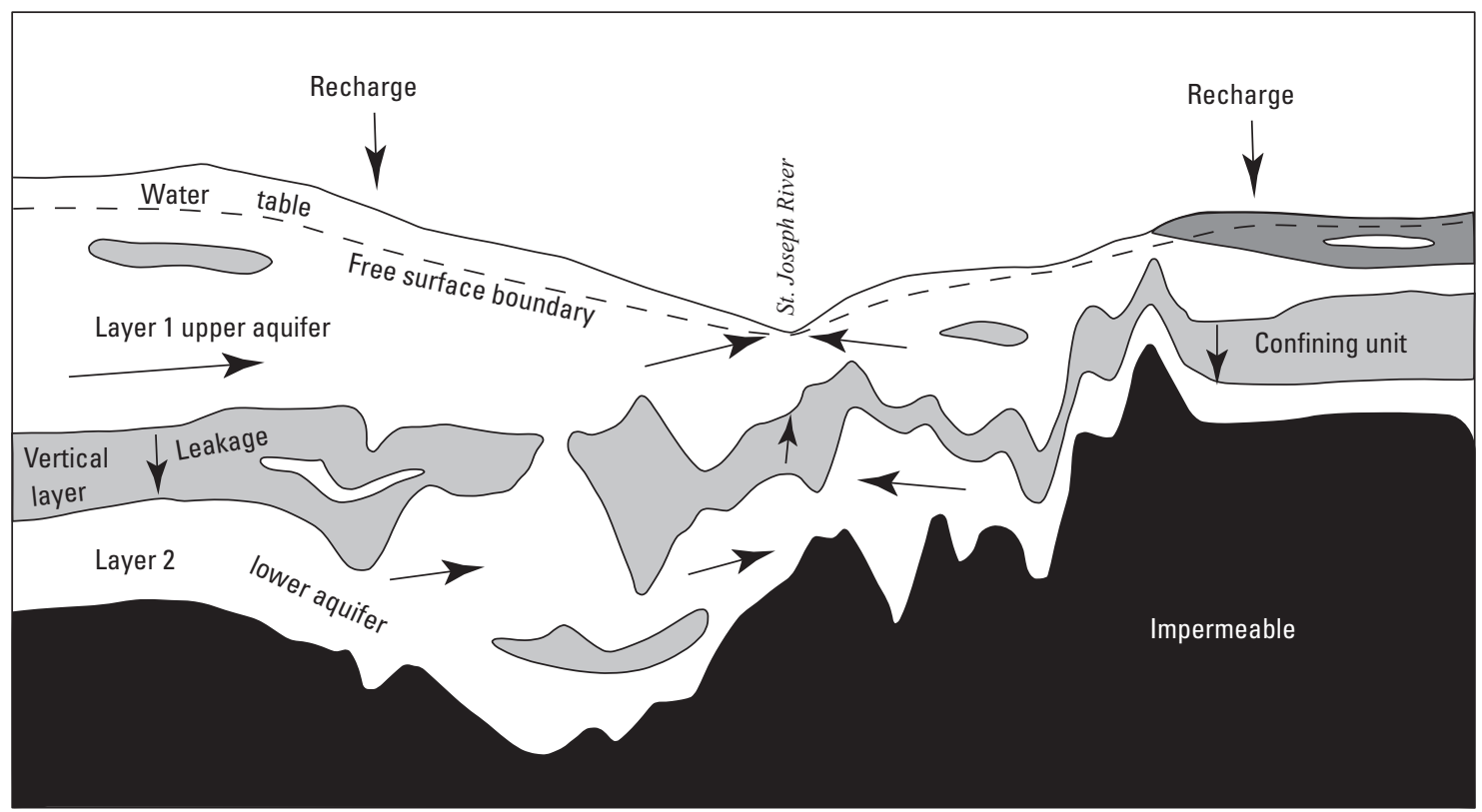

NOT TO SCALE

\section{EXPLANATION}

Arihood and Cohen, 1998

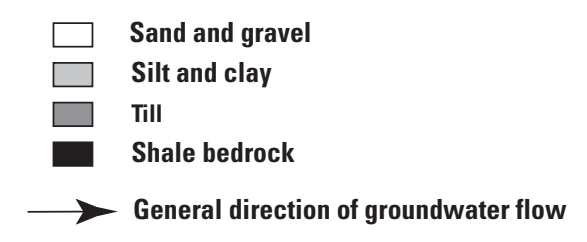

Figure 13. Diagrammatic section showing two model layers and boundary conditions used to represent major hydrogeologic units in Elkhart County, Indiana. 

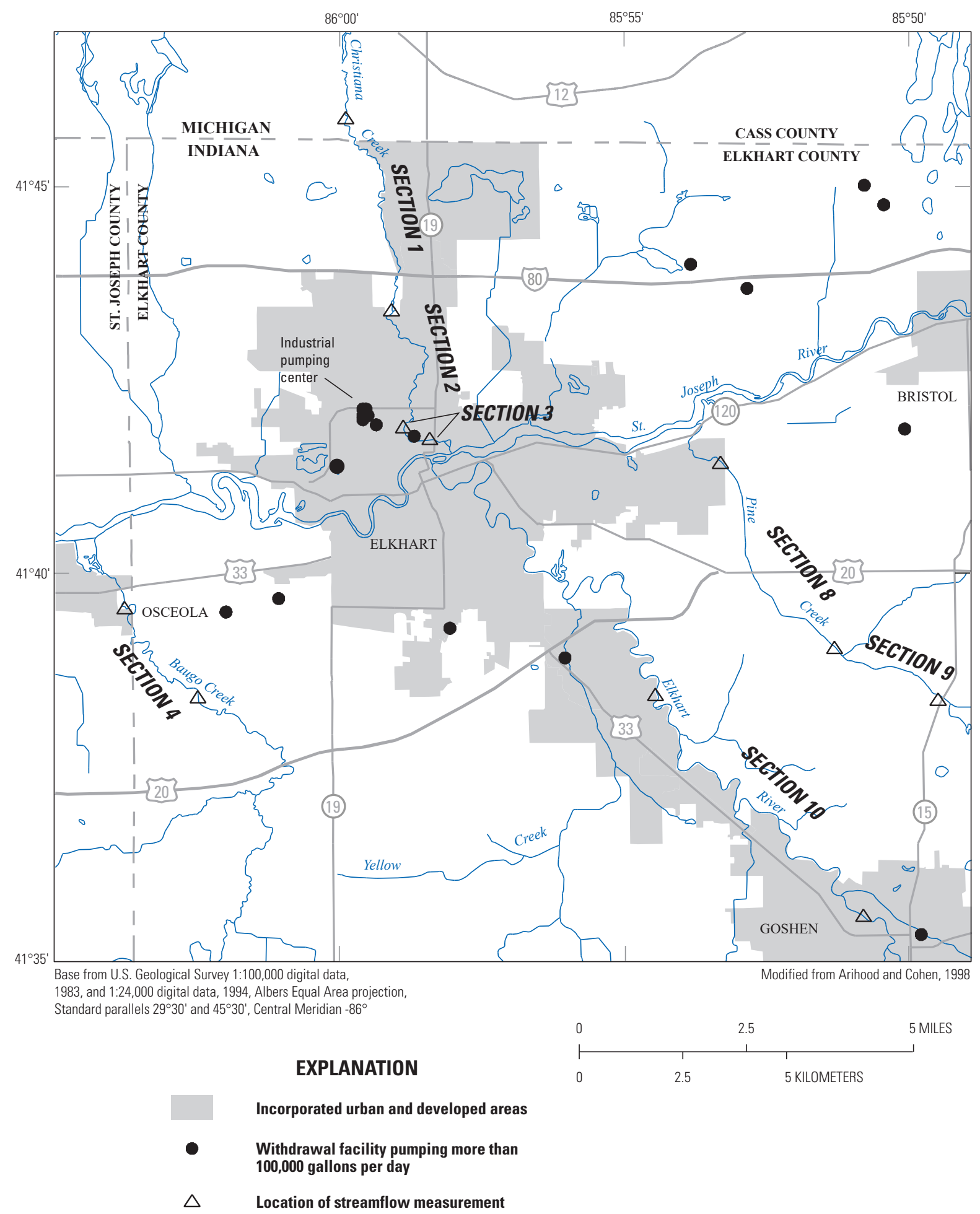

SECTION 3 Identifier of streamflow-measurement section

Figure 14. Location of streamflow measurement sections and withdrawal facilities that pumped more than 100,000 gallons per day during 1993 in Elkhart County, Indiana (from Arihood and Cohen, 1998). 


\section{Objective Model Calibration Procedure}

This section describes the calibration procedure for the objective model that used EVS software to estimate the horizontal hydraulic conductivity distribution. The calibration process used to calibrate the subjective model is described in detail in Arihood and Cohen (1998). An automated parameter-estimation method was used with the objective model, whereas a manual calibration procedure was used with the subjective model. The automated procedure used a nonlinear least-squares regression technique to estimate model-parameter values and improve overall calibration (Hill, 1998). The use of automated parameter estimation helps to determine, through sensitivity analysis, if unique parameter values for nonaquifer and mixtures of coarse and fine-grained deposits significantly affect groundwater levels and flow rates. The regression method for calibration requires that components of the groundwater system must be parameterized, parameters for calibration must be chosen (sensitivity analysis), and calibration data (observations) must be assigned weights.

\section{Nonlinear Least-Squares Regression Method}

Parameter values were automatically adjusted to select the best-possible fit between simulated and measured values. MODFLOW-2000 uses a nonlinear least-squares regression method to estimate values of several user-selected model parameters, such as horizontal hydraulic conductivity and recharge rate; therefore, the method can be more efficient than a trial and error calibration method. This parameter estimation process eliminates any potential bias that could result from the final parameter selection by the modeler. The numerical difference between the simulated and measured value (simulated minus observed) is called the residual. Parameter values are estimated by minimizing the sum of squared weighted residuals between simulated and measured observations of groundwater levels and flow rates to streams. Further discussion of this method is provided in Hill (1998).

\section{Model Parameterization}

Grid cells that were initially defined to have similar hydraulic properties were grouped together as a parameter zone and assigned a parameter value that was adjusted during the calibration process. Initially, six parameter zones were defined: these zones corresponded to the six horizontal hydraulic conductivity codes, or sediment types, listed in table 2 . The objective model was initially defined with 24 parameters to describe horizontal and vertical hydraulic conductivities and recharge rates (table 4) for each model component. Prefixes for the parameter names consist of the following: (1) K represents six horizontal hydraulic conductivity parameters, each corresponding to a horizontal hydraulic conductivity code (table 2) used within EVS; (2) KV represents six corresponding vertical hydraulic conductivity parameters; (3) D represents the two drain hydraulic conductance parameters; (4) R represents the six streambed hydraulic conductance parameters and (5) RECH represents the four recharge flux parameters. Four recharge flux parameters were used because four of the six lithology classifications (clay, sand, sand and gravel, and gravel) were at ground surface. The eight streambed parameters ( $R$ and $D)$ correspond to the eight values of streambed hydraulic conductivity used in the subjective model (Arihood and Cohen, 1998, p. 28) and were originally calculated using data collected during seepage runs (Arihood and Cohen, 1998; Imbrigiotta and Martin, 1981 Initial values for the six classes of horizontal hydraulic conductivity were selected from those given in Freeze and Cherry (1979, table 2.2), then revised to reflect expected values in the study area (Imbrigiotta and Martin, 1981. The vertical hydraulic conductivities of coarse-grained material were initially assumed to be 20 percent of the corresponding horizontal hydraulic conductivities, and the vertical hydraulic conductivities of fine-grained material were assumed to be 0.01 of the corresponding horizontal hydraulic conductivities. Both vertical hydraulic conductivities used in the objective model are similar to those presented by Imbrigiotta and Martin (1981) and were the same as used in the subjective model.

\section{Observation Dataset}

About 140 hydraulic-head observations from USGS observation wells and 9 streamflow observations from the calibration dataset. Both datasets were collected in 1979 by Imbrigiotta and Martin (1981) to calibrate a similar model and used again by Arihood and Cohen (1998) to calibrate a revised groundwater model of the same area of Elkhart County. About 70 percent of the water-level observations are from the upper part of the groundwater system, and about 30 percent of the water-level observations are from the lower part of the groundwater system. Thirty water-level observation sites had observation wells in the upper and lower aquifer (nested wells). Well locations are shown in the aerial plot of residuals shown in the "Residual Analysis" section. The streamflow observation measurements were made along the following major streams: Elkhart River, Baugo Creek, Christiana Creek, and Pine Creek (fig. 14).

\section{Weights Applied to Observations}

The purpose of weighting the objective model calibration observations is twofold. Weighting reduces the influence of observations (groundwater-level and streamflow gain/loss measurements) that are less accurate and increase the influence of observations that are more accurate. Also, weighting produces weighted residuals (a measure of the difference between the observation and its simulated equivalent) that have the same units, whether the residual is for water-level or streamflow gain/loss measurements. Water-level and flow residuals in the same units allow both residuals to be included in the 
sum of squared errors to be minimized. Weights on observation data account for measurement error associated with the accuracy of the sampling device (water-level tape or streamflow meter), method of determining land surface, the inclusion of surface water in the groundwater discharge measurement, data from wells with unknown screened intervals of wells, and other sources of uncertainty. In theory, weighted observations used in the regression procedure can be calculated from estimates of the variance of measurement error (Hill, 1998, p. 45-47). The weights are proportional to one divided by the variance of the measurement errors for the observation. To estimate these variances, MODFLOW-2000 reads statistics on measurement error (supplied by the user) from which the variances of the observation errors and the weights are calculated. The standard deviation of the measurement error was used to estimate the weights for water-level observations, and the coefficient of variation was used to estimate the error for the streamflow gain/loss observations. The calculations of the statistics are described in Hill (1998, p. 46-47).

Weights for the water-level observations were based on the assumption that 95 percent of the measurements were within the measurement error, which was considered to be $0.03 \mathrm{ft}$. Statistical theory for normally distributed populations states that for the 95-percent confidence interval, the measurement error should be 1.96 times the standard deviation of the measurement error (Cooley and Naff, 1990, p. 44). The standard deviation of the measurement error, therefore, is equal to 0.0153 ( 0.03 divided by 1.96 ), which is used as an input to MODFLOW-2000 for calculating water-level weights.

Weights for streamflow observations were calculated by dividing one by the streamflow multiplied by the coefficient of variation associated with the difference between streamflows. The coefficient of variation is calculated by finding the standard deviation of the upstream and downstream streamflow errors, then squaring each standard deviation to obtain variances for each streamflow error. The variance of the streamflow gain or loss is then calculated by adding the two variance values associated with each measurement. The coefficient of variation is determined by dividing the square root of the summed variances of the streamflow gain or loss (a standard deviation) by the streamflow gain or loss in the stream segment. The coefficients of variation used during calibration ranged from 0.1 to 1.4 and averaged 0.6.

\section{Parameter Sensitivities}

Decisions to estimate specific parameters were based on the sensitivity of simulated water levels to changes in model parameters. The sensitivity of simulated water levels with respect to various parameters was calculated using the sensitivity equation method (Hill and others, 2000). Composite scaled sensitivities (CSS) were calculated for each parameter. CSS aid in determining if the calibration data provide adequate information to estimate a particular parameter. CSS values less than about 0.01 times the largest CSS of all the parameters indicate that the nonlinear regression method may not be able to estimate the parameter (Hill, 1998, p. 38). At the beginning of calibration, several hydraulic conductivities (including streambed hydraulic conductivities), vertical hydraulic conductivities, and recharge rates of individual geologic deposits seemed to be sufficiently sensitive to attempt parameter estimation. During calibration, many of the parameters became less sensitive and could not be estimated as other parameter values changed.

\section{Objective Model Calibration Results}

The objective model was calibrated through a process of adjusting the model input parameters to produce the best match between simulated and measured hydraulic heads and flows. Optimal values should correspond to minimal differences between measured values and their simulated equivalents. The differences, called residuals, should be unbiased and randomly distributed.

\section{Optimal Parameter Estimates}

Although calibration of the objective model began with estimating 24 parameters, only 4 could be successfully estimated at the end of calibration. The remaining 11 parameters were dropped out of the estimation process either because (1) the parameter became insensitive as other parameter values changed, (2) the regression process was estimating similar values for different parameters (in which case the parameters were combined as in $\mathrm{K} 1$ being combined with $\mathrm{K} 2$ ), or (3) the estimated values became unreasonable. The parameters that could be estimated and their optimal values are listed in table 5 along with the remaining parameters that were not estimated. The remaining parameter values either were not changed during calibration or, in the case of recharge, set to values used by Arihood and Cohen (1998). For example, recharge parameters were removed from the automated calibration process when unreasonably high values were being estimated. The reason for the overestimation could not be determined from an analysis of influential observations. The parameter representing recharge to the clay was set to $4 \mathrm{in} / \mathrm{yr}$, and the other recharge parameters for coarse-grained deposits were set to $16 \mathrm{in} / \mathrm{yr}$ as in Arihood and Cohen (1998).

Characteristics of the horizontal hydraulic conductivity distribution calculated by the EVS software may have affected the parameters that could be estimated. Deposits along the major flow paths through the model should have sensitive parameters, and the parameters should be capable of being estimated. In the subjective model (Arihood and Cohen, 1998), groundwater must flow through a confining unit to reach the lower aquifer, making vertical hydraulic conductivity of the confining unit a sensitive parameter that could be estimated. The calibrated solution of the objective model was insensitive to values used to simulate horizontal and vertical hydraulic conductivities of fine-grained deposits that would 
Table 5. Values used for objective model parameters.

[ft/d, foot per day; in/yr, inch per year]

\begin{tabular}{|c|c|c|}
\hline Parameter name & Model component represented & Value used in calibration \\
\hline $\mathrm{K} 1, \mathrm{~K} 2$ & Horizontal hydraulic conductivity of sand and gravel and gravel & $111 \mathrm{ft} / \mathrm{d}^{1}$ \\
\hline K3 & Horizontal hydraulic conductivity of sand & $23.9 \mathrm{ft} / \mathrm{d}^{1}$ \\
\hline R01 & Hydraulic conductivity of river streambed cells, originally estimated to be $0.1 \mathrm{ft} / \mathrm{d}$ & $0.567 \mathrm{ft} / \mathrm{d}^{1}$ \\
\hline R005 & Hydraulic conductivity of river streambed cells, originally estimated to be $0.05 \mathrm{ft} / \mathrm{d}$ & $0.205 \mathrm{ft} / \mathrm{d}^{1}$ \\
\hline K4 & Horizontal hydraulic conductivity of silty sand & $5.0 \mathrm{ft} / \mathrm{d}$ \\
\hline K5, K6 & Horizontal hydraulic conductivity of silt and clay & $1.0 \mathrm{ft} / \mathrm{d}$ \\
\hline KV1, KV2 & Vertical hydraulic conductivity of sand and gravel and of gravel & 30 \\
\hline KV3 & Vertical hydraulic conductivity of sand & 4 \\
\hline KV4 & Vertical hydraulic conductivity of silty sand & 1 \\
\hline KV5, KV6 & Vertical hydraulic conductivity of silt and clay & 0.07 \\
\hline D1 & Hydraulic conductivity of drains initially assigned a hydraulic conductivity of $1 \mathrm{ft} / \mathrm{d}$ & $1.0 \mathrm{ft} / \mathrm{d}$ \\
\hline D001 & Hydraulic conductivity of drain beds initially assigned a value of $0.01 \mathrm{ft} / \mathrm{d}$ & $0.01 \mathrm{ft} / \mathrm{d}$ \\
\hline $\mathrm{R} 50$ & Hydraulic conductivity of river beds initially assigned a value of $50 \mathrm{ft} / \mathrm{d}$ & $50 \mathrm{ft} / \mathrm{d}^{2}$ \\
\hline R1 & Hydraulic conductivity of river beds initially assigned a value of $1 \mathrm{ft} / \mathrm{d}$ & $1 \mathrm{ft} / \mathrm{d}^{2}$ \\
\hline R05 & Hydraulic conductivity of river beds initially assigned a value of $0.5 \mathrm{ft} / \mathrm{d}$ & $0.5 \mathrm{ft} / \mathrm{d}^{2}$ \\
\hline R001 & Hydraulic conductivity of river beds initially assigned a value of $0.01 \mathrm{ft} / \mathrm{d}$ & $0.01 \mathrm{ft} / \mathrm{d}^{2}$ \\
\hline $\mathrm{RECH} 2$ & Recharge rate to till & $4 \mathrm{in} / \mathrm{yr}^{2}$ \\
\hline RECH16 & Recharge rate to sand, sand and gravel, and gravel & $16 \mathrm{in} / \mathrm{yr}^{2}$ \\
\hline
\end{tabular}

${ }^{1}$ Value obtained by parameter estimation.

${ }^{2}$ Value from Arihood and Cohen, 1998, table 4.

represent a confining unit, indicating that a continuous confining unit does not generally exist in the objective model. The coarse-grained deposits were sensitive, possibly indicating a continuous horizontally and vertically connected series of sand and gravel deposits along which major flow paths through the aquifer system are developed. The "Calibrated GroundwaterFlow Paths" section provides further information on major flow paths calculated by the two models. Only four hydraulic conductivity parameters could be estimated using the parameter estimation technique, including the hydraulic conductivity of the sand unit and the combined sand and gravel and gravel units. The ability to distinguish the two deposits indicates the need to improve mapping of the extents of the two deposits in future model simulations of the aquifer.

\section{Residual and Correlation Analysis}

The degree of fit between field-measured and model-simulated values is an indication of how well the objective model represents the actual groundwater-flow system. Model fit can be measured in multiple ways, including plots of measured water levels in relation to simulated water levels, the correlation coefficient between those values, and water-level residuals. Residuals can be analyzed in terms of their distribution and degree of bias (sum of residuals divided by number of observations).

Ideally, simulated values should be close to measured values such that when weighted observations are plotted against weighted simulated values, the residual values fall close to a line with slope equal to 1 and intercept of 0 (1:1 line). The plot of weighted simulated water levels in relation to weighted measured water levels is shown in figure $15 \mathrm{~A}$. The correlation coefficient between weighted simulated values and weighted measured values reflects how well the values follow the 1:1 line. A correlation coefficient greater than 0.90 is desirable and the calibration of the model resulted in a value of 0.99988 .

Valid parameter estimation should result in normally distributed weighted residuals. The weighted residuals are plotted according to their position in an assumed normal distribution (fig. 15B). If the residuals are truly normally distributed, then the residuals should plot along a straight line. The statistic that measures the linearity of the plot, as well as the independence of one residual to another, is called the correlation between ordered weighted residuals and normal order statistics. This correlation coefficient also should be near 1 , and the value associated with the model calibration is 0.974 for this study, indicating the residuals approximate a normal distribution. 


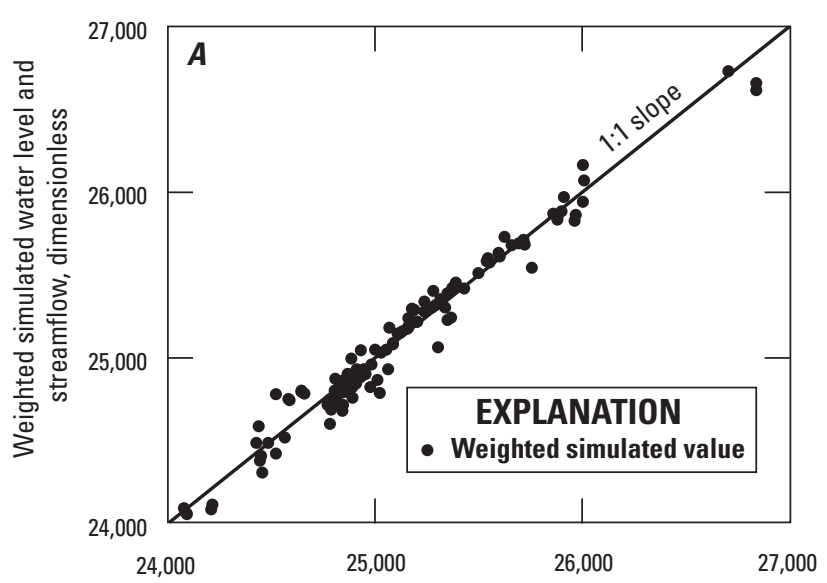

Weighted measured value, dimensionless
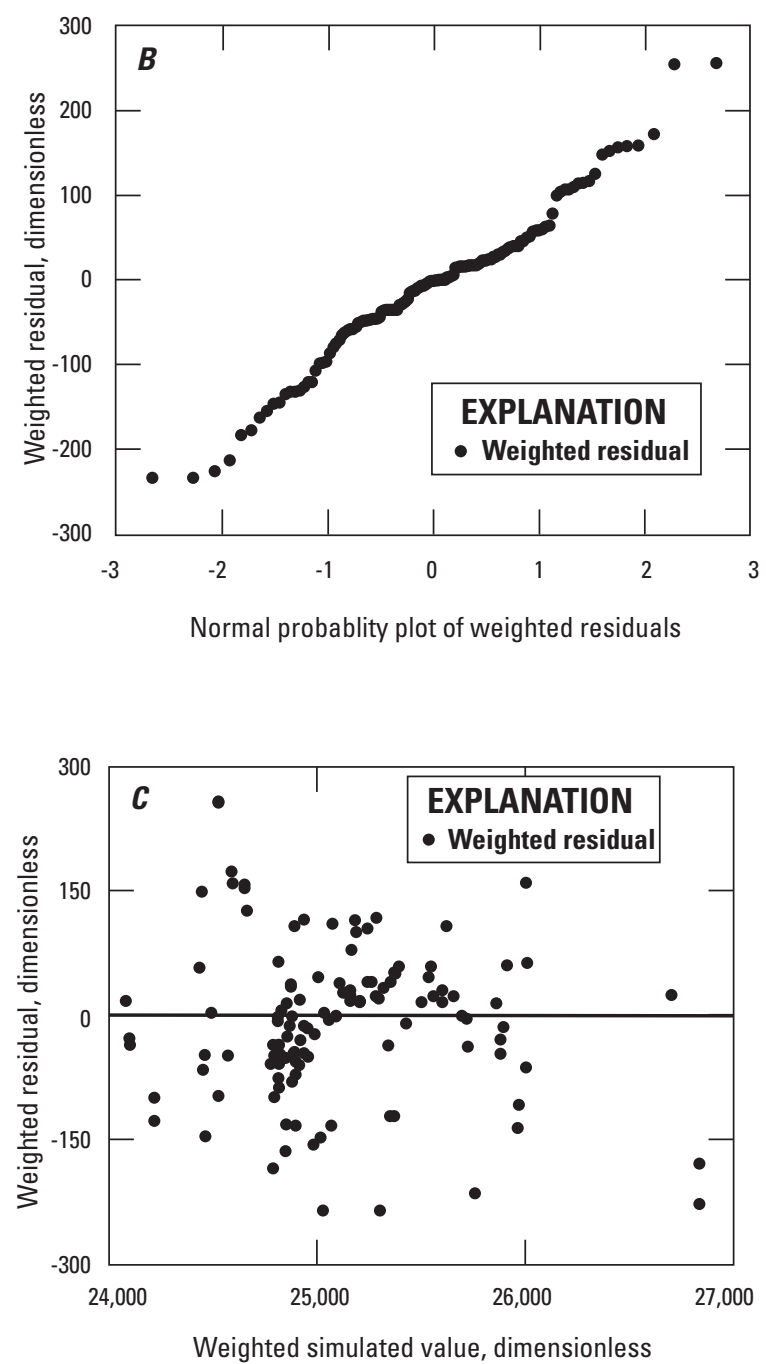

Figure 15. Graphical analysis of model fit for the objective model, $A$, weighted simulated and weighted measured water levels; $B$, normal probability plot of weighted residuals; and $C$, weighted residuals and weighted simulated values.
Weighted residuals and their weighted simulated values are shown in figure $15 C$ to evaluate positive or negative bias. Ideally, the weighted residuals should be evenly distributed at about zero and not biased positively or negatively. Also, the size of the weighted residuals should not be related to the magnitude of the weighted simulated values (for example, large residuals associated with lower simulated values). These requirements were generally satisfied in model calibration.

Residuals also can be analyzed by their aerial distribution and magnitude. The map of nonweighted water-level residuals in the objective model indicates a mix of positive and negative residuals over the model area (fig. 16). Residuals indicate differences in the simulated water budget from actuals. The only area indicating a residual bias is an area of negative residuals in the northwest part of the study area. The reason for the negative residuals is unknown, and model simulations in this area are not as reliable as in the rest of the model area. The positive and negative trends in residuals can be explained mostly by concentrated clusters of wells in some areas, such as just east of the confluence of the St. Joseph and Elkhart Rivers. The multiple positive residuals are not indicating a simulation bias, but a repeated representation of the same local area where simulated values exceed measured values. The positive and negative patterns in the residuals also were present in the subjective model (Arihood and Cohen, 1998, p. 30). The clustering also can be seen in the lower one-half of figure $15 \mathrm{C}$.

\section{Comparison of Groundwater-Model Flow Simulations}

The subjective and objective models differed in the calibration results and representations of groundwater flow. The differences between the two models are presented in terms of their accuracy, parameter values, water budgets, water-level contours, flow paths, and travel times. Model accuracy and water budgets are associated with conditions during the calibration period in 1979. The water-level contours and the groundwater flow paths and travel times discussed at the end of this section are associated with conditions during the simulation period used by Arihood and Cohen in 1993. Archives of both models are available as a data release at https://doi.org/10.5066/F7QN65RW (Arihood, 2019).

\section{Model Accuracy and Parameter Values}

The accuracy of the subjective and objective models in reproducing measured groundwater levels was assessed by the three statistics that are available for both models (table 6). The mean absolute error value between simulated and measured groundwater levels for the objective model $(2.04 \mathrm{ft})$ was slightly better than the error for the subjective model (2.16 ft). Also, the standard deviation of the errors for the objective model is somewhat smaller. The smaller number indicates that 


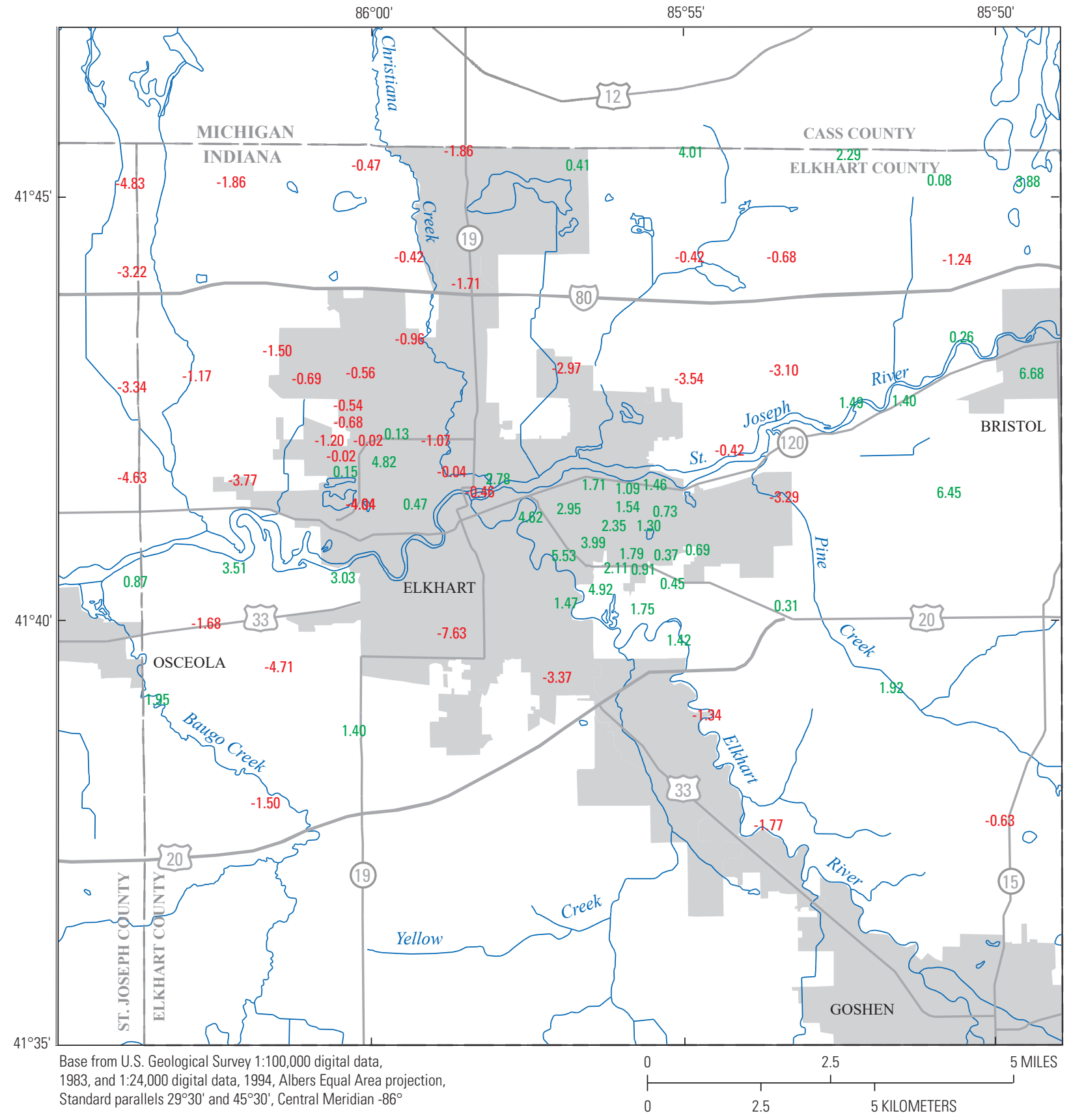

\section{EXPLANATION}

Incorporated urban and developed areas

-0.63 0.87 Difference between the simulated and

measured groundwater level, in feet.

Red values indicate negative residuals

(simulated values less than measured),

and green values indicate positive residuals

Figure 16. Differences between the nonweighted simulated and measured water levels for the objective model. Water levels were measured May and June 1979. 
Table 6. Model accuracy in groundwater levels for the subjective and objective models.

\begin{tabular}{lccc}
\hline Model & $\begin{array}{c}\text { Mean } \\
\text { absolute error, } \\
\text { in feet }\end{array}$ & Bias & $\begin{array}{c}\text { Standard } \\
\text { deviation of error, } \\
\text { in feet }\end{array}$ \\
\hline Subjective & 2.16 & 0.09 & 3.26 \\
Objective & 2.04 & -0.25 & 2.73 \\
\hline
\end{tabular}

the middle two-thirds of the distribution of residuals associated with the objective model is somewhat smaller than that computed by the subjective model. The bias associated with the objective model is slightly greater. The improvement associated with the detailed objective model in representing groundwater levels did not result from increased detail in horizontal hydraulic conductivity. The improvement may be from increased detail in the distribution of fine- and coarse-grained deposits, as was provided by the additional number of well records used in the construction of the objective model. The improvement also could be associated with the difference in methods used to represent the continuity of the confining unit or the different calibration techniques (manual versus parameter estimation).
Noticeably different values of horizontal hydraulic conductivity were estimated for the subjective and objective models, but the mean absolute errors were similar for both models. Horizontal hydraulic conductivity of coarse-grained deposits in the subjective model generally ranged from 170 to $370 \mathrm{ft} / \mathrm{d}$, whereas horizontal hydraulic conductivities of the same sediment type in the objective model ranged from 23.9 to $111 \mathrm{ft} / \mathrm{d}$ (table 5). The differing horizontal hydraulic conductivities in the two models created different overall flow rates for the two models, which is discussed in the "Water Budgets" section.

\section{Calibrated Water Budgets}

The groundwater-model budgets for the subjective and objective models differ mostly in the total amount of inflow and outflow through the models and differ somewhat in the distribution of inflows to the models (tables 7 and 8 ). The total inflow and outflow through the subjective model is 58 percent greater than the rate through the objective model. The increased flow in the subjective model is a reflection of more continuous and abundant coarse-grained deposits in the subjective model and the higher horizontal hydraulic conductivities of those deposits, as compared to the objective model.

A greater percentage of inflow to the objective model is derived from recharge by precipitation and rivers than the

Table 7. Water budget for the subjective model determined by steady-state simulation, June 1979 (modified from Arihood and Cohen, 1998).

$\left[\mathrm{ft}^{3} / \mathrm{s}\right.$, cubic foot per second; \%, percent; NA, not applicable]

\begin{tabular}{|c|c|c|c|c|c|}
\hline \multirow{2}{*}{$\begin{array}{l}\text { Source of inflow to model } \\
\text { Constant-head boundaries }\end{array}$} & \multicolumn{2}{|c|}{$\begin{array}{l}\text { Inflow rate }\left(\mathrm{ft}^{3} / \mathrm{s}\right) \text { and } \\
\text { percent of total }\end{array}$} & \multirow{2}{*}{$\begin{array}{l}\text { Source of outflow from model } \\
\text { Constant-head boundaries }\end{array}$} & \multicolumn{2}{|c|}{$\begin{array}{l}\text { Inflow rate }\left(\mathrm{ft}^{3} / \mathrm{s}\right) \text { and } \\
\text { percent of total }\end{array}$} \\
\hline & 153 & $(45.6 \%)$ & & 34.3 & $(10.2 \%)$ \\
\hline Precipitation recharge & 165 & $(49.3 \%)$ & Discharge to wells & 17.6 & $(5.3 \%)$ \\
\hline Recharge from wells & 2.5 & $(0.7 \%)$ & Discharge to streams & 283 & $(84.5 \%)$ \\
\hline Recharge from rivers & 14.6 & $(4.4 \%)$ & NA & NA & NA \\
\hline Total inflow & 335 & NA & Total outflow & 335 & NA \\
\hline
\end{tabular}

Table 8. Water budget for the objective model determined by steady-state simulation, June 1979.

[ $\mathrm{ft}^{3} / \mathrm{s}$, cubic foot per second; $\%$, percent; NA, not applicable]

\begin{tabular}{|c|c|c|c|c|c|}
\hline \multirow{2}{*}{$\begin{array}{l}\text { Source of inflow to model } \\
\text { Constant-head boundaries }\end{array}$} & \multicolumn{2}{|c|}{$\begin{array}{l}\text { Inflow rate }\left(\mathrm{ft}^{3} / \mathrm{s}\right) \text { and } \\
\text { percent of total }\end{array}$} & \multirow{2}{*}{$\begin{array}{l}\text { Source of outflow from model } \\
\text { Constant-head boundaries }\end{array}$} & \multicolumn{2}{|c|}{$\begin{array}{l}\text { Inflow rate }\left(\mathrm{ft}^{3} / \mathrm{s}\right) \text { and } \\
\text { percent of total }\end{array}$} \\
\hline & 65.5 & $(31.0 \%)$ & & 23.9 & $(11.3 \%)$ \\
\hline Precipitation recharge & 120 & $(56.9 \%)$ & Discharge to wells & 12.7 & $(6.0 \%)$ \\
\hline Recharge from wells & 2.54 & $(1.2 \%)$ & Discharge to streams & 174 & $(82.5 \%)$ \\
\hline Recharge from rivers & 23.1 & $(10.9 \%)$ & NA & NA & NA \\
\hline Total inflow & 211 & NA & Total outflow & 211 & NA \\
\hline
\end{tabular}


subjective model, and a correspondingly smaller percentage of inflow is derived from the constant-head boundaries in the objective model than in the subjective model. The percentage of outflow to constant-head boundaries, wells, and streams is about the same in both models.

Discharge rates to water-withdrawal wells were different between the two models. The same well positions and withdrawal rates were input to each model, but some wells represented in the objective model went dry during the simulation. Wells going dry during a simulation may indicate that the distribution of aquifer material or the horizontal hydraulic conductivity of that material near the dry wells was not adequately being represented. The discharge lost from the objective model is a small percentage of total groundwater flow in the objective model (about 2 percent) and does not affect general conclusions about model performance.

Simulated gains to stream reaches in the subjective model are greater than gains to the same sections in the objective model (table 9). Streamflow gains or losses were measured in several stream reaches previously (Arihood and Cohen, 1998) and the data were used as calibration data. The simulated streamflow gains and losses for both models compared with measurements made in measured stream reaches are listed in table 9. The range in measured flows listed in column 2 of table 9 reflects the effect of measurement error in measuring streamflow. The larger volume of groundwater discharge (gain) to the measured stream reaches simulated by the subjective model resulted in simulated streamflow gains that were greater than the range of measured gains reported by Arihood and Cohen (1998) (table 9). Simulated groundwater discharges for the subjective model are over the potential range of measured streamflow gains along four of seven reaches, whereas only two simulated streamflow gains and one loss are within the potential range (table 9). In contrast, simulated gains to stream reaches in the objective model are more balanced. For the objective model, four simulated streamflow gains and one loss were within the potential range of measured flow; two gains were over the potential range, and one gain was under the potential range (table 9). The improvement in matching measured groundwater fluxes to streams associated with the objective model may be because of a more accurate representation of the depositional environment by the objective model, but also because of a superior calibration technique (parameter estimation) used by the objective model.

\section{Water-Level Contours}

Groundwater flow in each model is illustrated by waterlevel contours that provide water-level altitude data and infer direction of flow. Simulated water-level contours for the upper aquifer in the subjective model are shown in figure 17, and simulated water-level contours for the objective model are shown in figure 18. The shape and location of the water-level contours for each model are similar, indicating similar water levels and groundwater-flow patterns. An exception, however, is an indication of drawdown in groundwater levels as represented in the $740 \mathrm{ft}$ contour as a result from pumping at withdrawal wells as shown near the center of figure 18. A possible reason that the subjective model does not indicate drawdown at a withdrawal well location (fig. 17) is because a continuous confining unit separates the pumping well in layer 2 from the upper aquifer; the upper aquifer contours are shown in figure 17. Simulated water-level contours of the subjective model do indicate drawdown in the lower aquifer (Arihood and Cohen, 1998, p. 32).

Table 9. Comparison of simulated streamflow gain or loss to measured values for the subjective and objective model.

$\left[\mathrm{ft}^{3} / \mathrm{s}\right.$, cubic foot per second]

\begin{tabular}{|c|c|c|c|}
\hline $\begin{array}{l}\text { Stream section } \\
\text { (fig. 1) }\end{array}$ & $\begin{array}{l}\text { Range of measured } \\
\text { streamflow gain or loss } \\
\left(\mathrm{ft}^{3} / \mathrm{s}\right)\end{array}$ & $\begin{array}{c}\text { Simulated gain or loss } \\
\text { in subjective model }{ }^{1,2} \\
\left(\mathrm{ft}^{3} / \mathrm{s}\right)\end{array}$ & $\begin{array}{c}\text { Simulated gain or loss } \\
\text { in objective model } \\
\left(\mathrm{ft}^{3} / \mathrm{s}\right)\end{array}$ \\
\hline 1 & 4.4 to 18.3 & 19.8 & 12.3 \\
\hline 2 & -3.7 to 11.7 & 4.30 & 2.70 \\
\hline 3 & -18.5 to -3.7 & -8.95 & -7.99 \\
\hline 4 & 4.4 to 6.8 & 8.56 & 1.89 \\
\hline 8 & 1.8 to 3.3 & 5.48 & 4.51 \\
\hline 9 & 1.4 to 2.3 & 3.08 & 2.89 \\
\hline 10 & 3 to 41 & 17.7 & 16.7 \\
\hline
\end{tabular}

${ }^{1}$ Negative value indicates flow loss from the stream reach.

${ }^{2}$ From Arihood and Cohen (1998). 


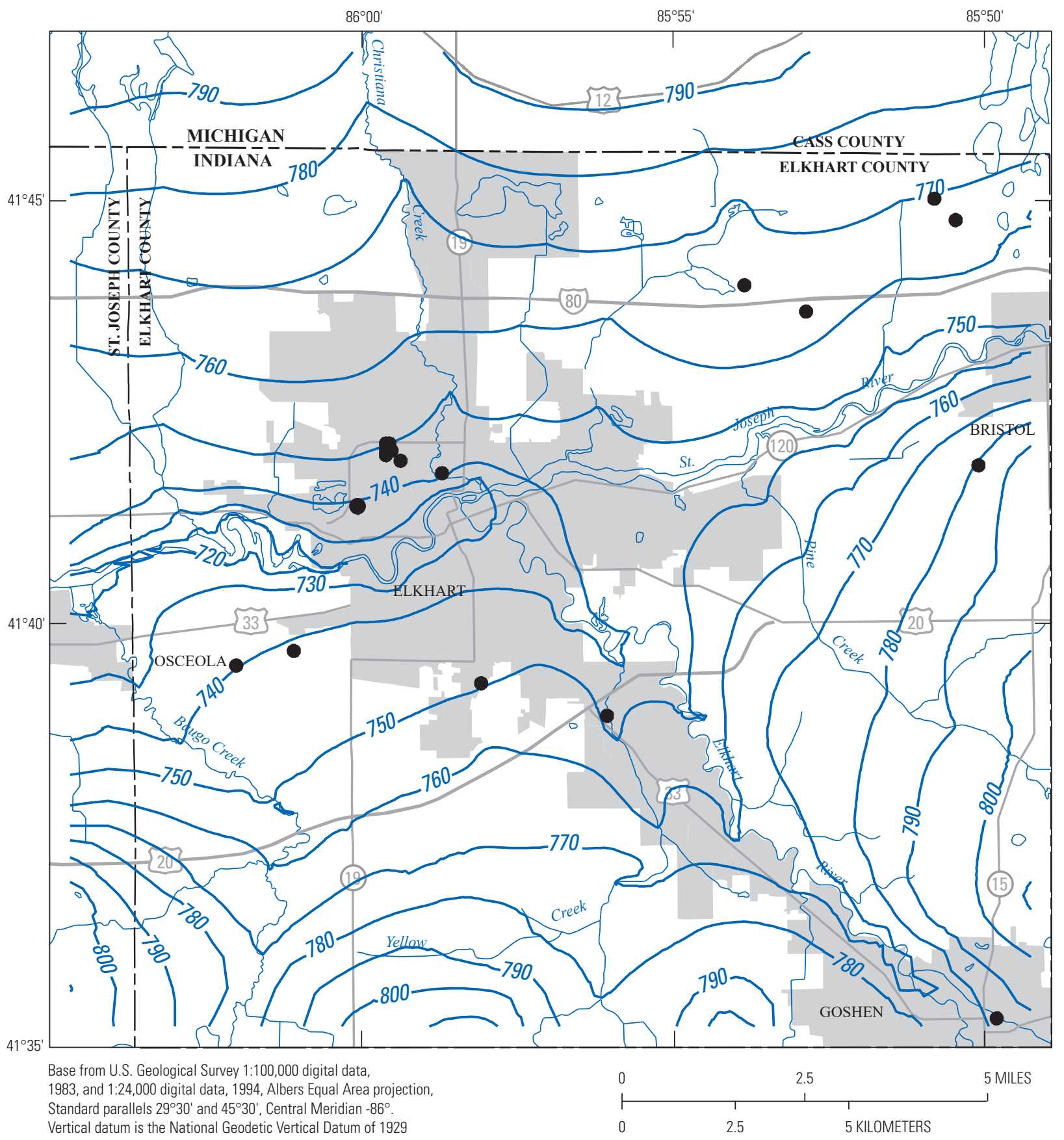

\section{EXPLANATION}

Incorporated urban and developed areas

- 800 - Simulated water-level contour, in feet above

the National Geodetic Vertical Datum of 1929.

Contour interval 10 feet

Withdrawal facility pumping more than

100,000 gallons per day

Figure 17. Simulated water-level contours for the upper aquifer (layer 1) in the subjective model. 


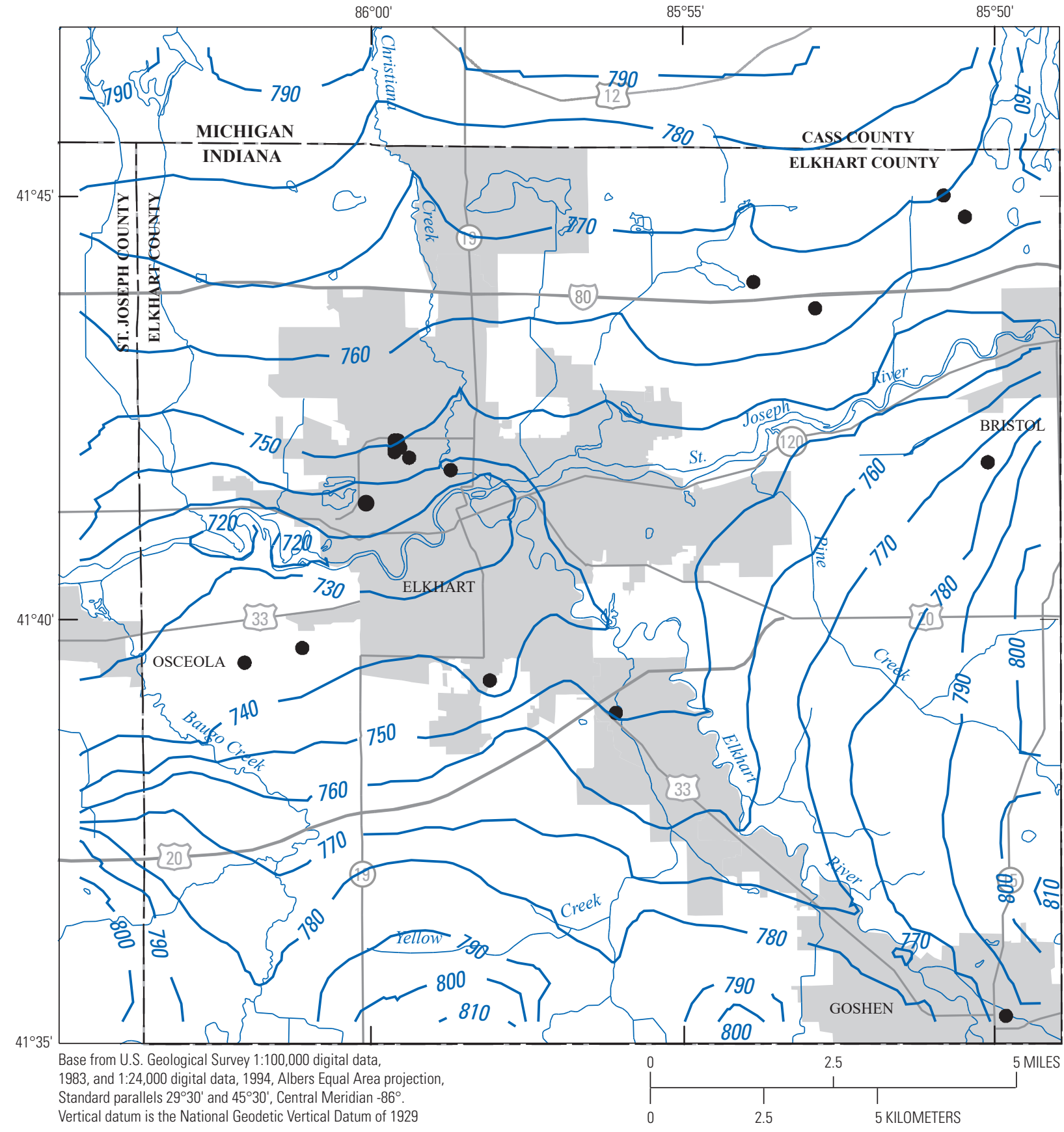

\section{EXPLANATION}

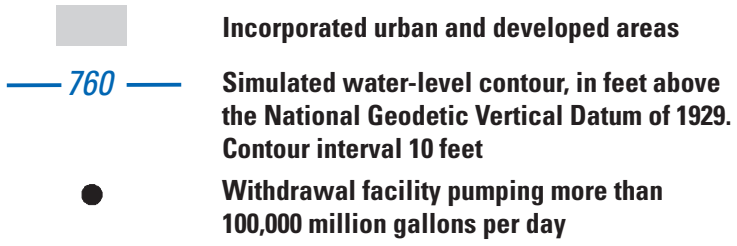

Figure 18. Simulated water-level contours for layer 12 in the objective model. 


\section{Groundwater-Flow Paths}

Groundwater-flow paths can provide information on the source, distribution, and discharge of groundwater. Flow paths from recharge point to discharge point were generated for model nodes in every fifth model row and column for the subjective and objective model simulations (figs. 19 and 20, respectively). Flow paths were generated using MODPATH, a particle-tracking post-processing package for MODFLOW. The subjective model used version 3 of MODPATH (Pollock, 1994) and the objective model used version 4 of that program. MODPATH computes flow paths for imaginary particles of water moving through the simulated groundwater system. The particles are considered conservative and nonreactive and their movement and fate is controlled by advection. Generally, recharge to groundwater in a given area discharges to the same streams in both models. An overall difference is that the flow paths for the subjective model are slightly smoother than flow paths for the objective model, reflecting the more abundant and continuous coarse-grained deposits in the subjective model. Flow-path differences were apparent in the central part of the model area along the downstream end of the Elkhart River and in the south-central part near a withdrawal well location (fig. 19). At the downstream end of the Elkhart River, flow paths associated with the objective model are short, indicating locally derived water. Short and long flow paths are associated with the subjective model for the same section of the Elkhart River. At the withdrawal-well location, the flow lines for the objective model indicate a wider contributing area (fig. 20) as compared to the subjective model. The greater contributing area reflects the lower horizontal hydraulic conductivity used in the objective model.

Flow paths along a north-south cross section also were calculated for the subjective and objective models to illustrate any differences in vertical flow paths between the two models. The aerial location of the cross section is shown in figure 21, and the flow paths are shown in figure 22. Column 29 was chosen as the starting location of flow paths because waterquality data helpful in defining flow-path locations are available along that column from a previous study (Duwelius and Silcox, 1991). Water-quality samples were collected at different depths along a geologic cross section that generally follows the location of column 29 in the groundwater models. Those samples were analyzed for bromide concentrations to evaluate presence of landfill-related leachate in groundwater. Contours of bromide concentrations drawn by Duwelius and Silcox (1991, fig. 12 on p. 35) indicate that groundwater flow near the focus area shown in the figure split into upper and lower paths around an isolated confining unit. The location of the confining unit is indicated by the focus area in figure 22 of this report. In the objective model, the confining unit is absent, and flow moves downward at column 29 , as inferred from the bromide contours (Duwelius and Silcox, 1991, p. 35). Because the subjective model represents the confining layer as a mostly continuous deposit, simulated groundwater flow does not move downward at this location along the north-south cross section (column 29). Simulated groundwater flow in both simulations curves east away from the section represented by column 29 to an industrial pumping center (fig. 14) and does not flow downward through the confining unit until the flow lines reach the pumping center.

Two additional differences between the models are evident in figure 22. In the subjective model, flow paths north of the St. Joseph River are grouped together and remain above the confining unit. In the objective model, flow paths begin to spread vertically north of the river, which reflects the model's greater heterogeneity in its hydrostratigraphy. The second difference between the models pertains to the interpretation of the cross section itself. The cross section for the objective model is deeper because the objective model included additional wells, sometimes indicating greater depth of unconsolidated deposits than the limited number of wells used to construct the subjective model. A greater thickness in the potential flow field provides opportunity for a greater spread in flow paths. The differences in flow paths can potentially result in differences of water age, distribution of contaminants, and general water quality.

Some of the flow lines in figure 22 seem to flow outside of the model domain. All flow lines begin at the water-table surface along column 29 and then continue either in or out of column 29 in the horizontal plane. A flow line that seems to be below the bottom of the model is actually still within the model, but is within another model column and layer that is part of the model domain. Although the flow lines may move out of column 29 (temporarily or permanently), the line work on figure 22 is always projected onto the cross section of column 29 for easier visualization.

\section{Groundwater Travel Times}

In general, flow paths associated with the complex geology of the objective model are older than those associated with the more simplified subjective model. Travel times from recharge points to discharge points shown in figure 22 average 42.8 years and as many as 305 years for the objective model, whereas travel times for the subjective model average 20.3 years and as many as 162 years. In both cases, most of the oldest flow paths traveled around extensive fine-grained deposits that are south of the St. Joseph River before flowing through coarse-grained deposits toward groundwater discharges at withdrawal wells and streams. The porosity assumed for the travel time simulations is 0.30 .

\section{Model Limitations of the Objective and Subjective Models}

Model limitations are somewhat similar to those described for the subjective model (Arihood and Cohen, 1998, p. 44-45), such as the need for greater stresses (pumpage or aquifer withdrawals) to confirm that the response of the groundwater-flow system adequately describes 


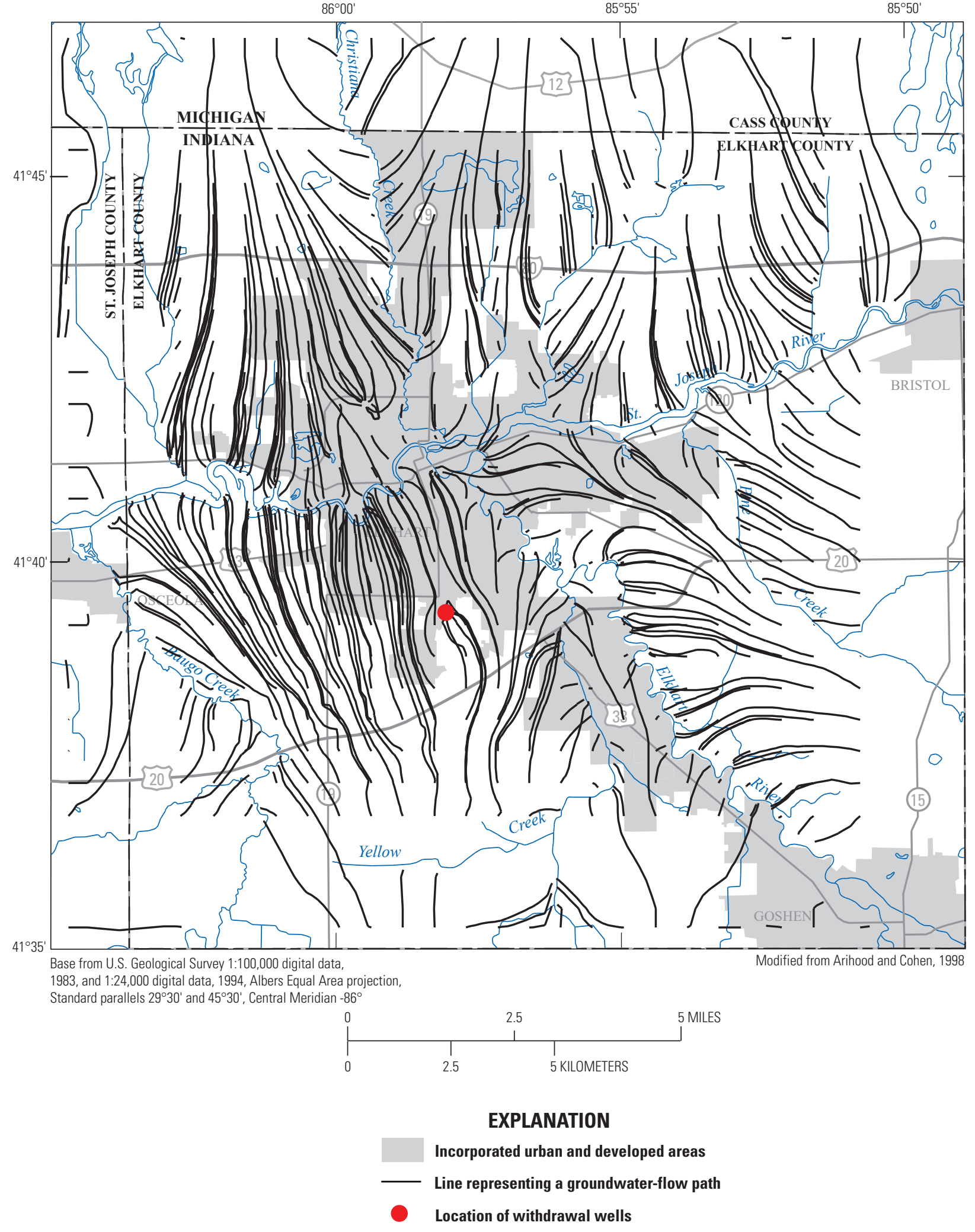

Figure 19. Flow lines representing the path of groundwater from points of recharge to points of discharge for the subjective model. 


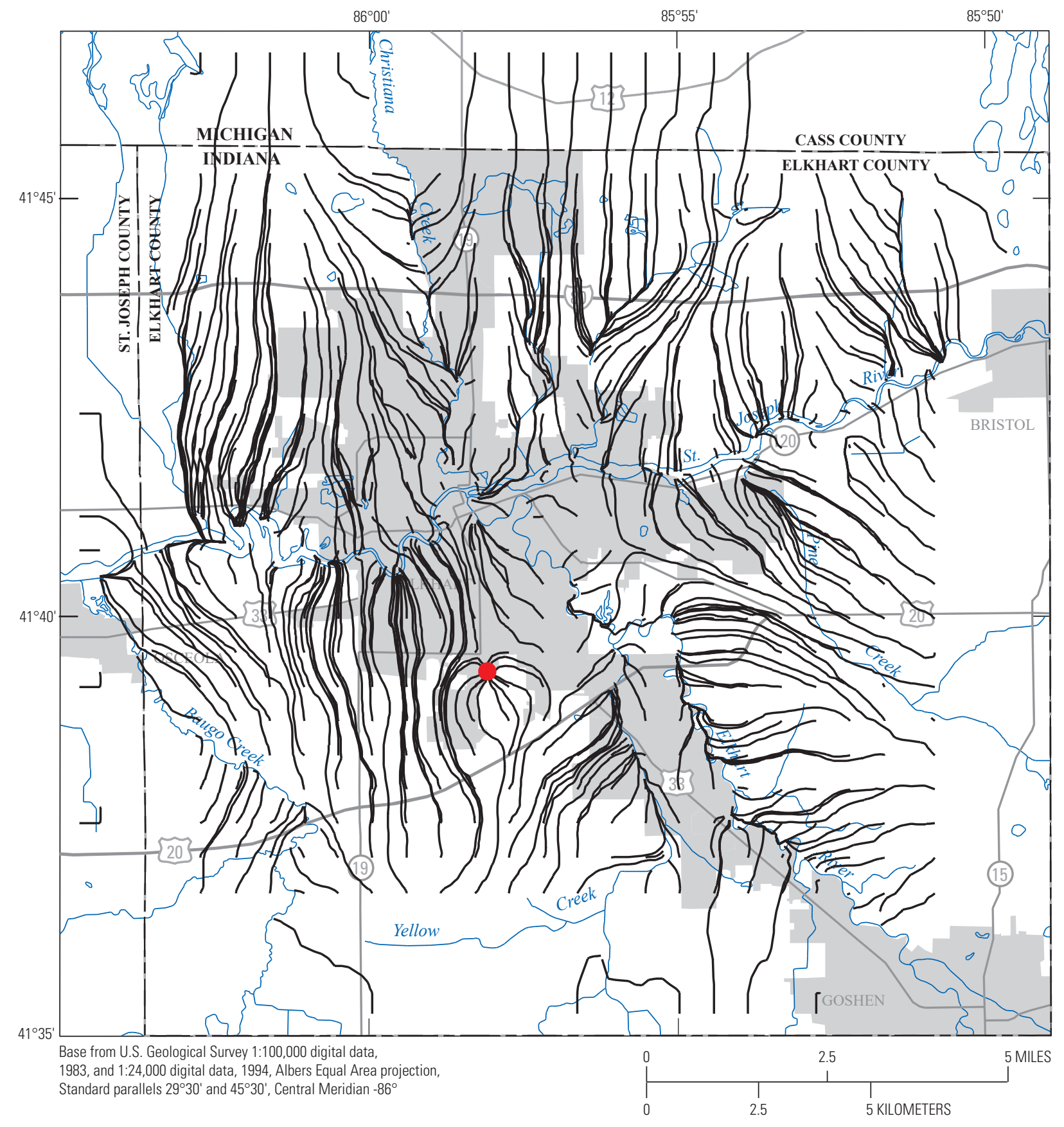

EXPLANATION

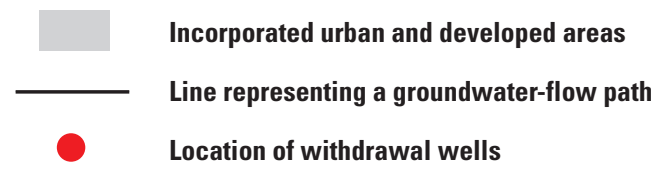

Figure 20. Flow lines representing the path of groundwater from points of recharge to points of discharge for the objective model. 


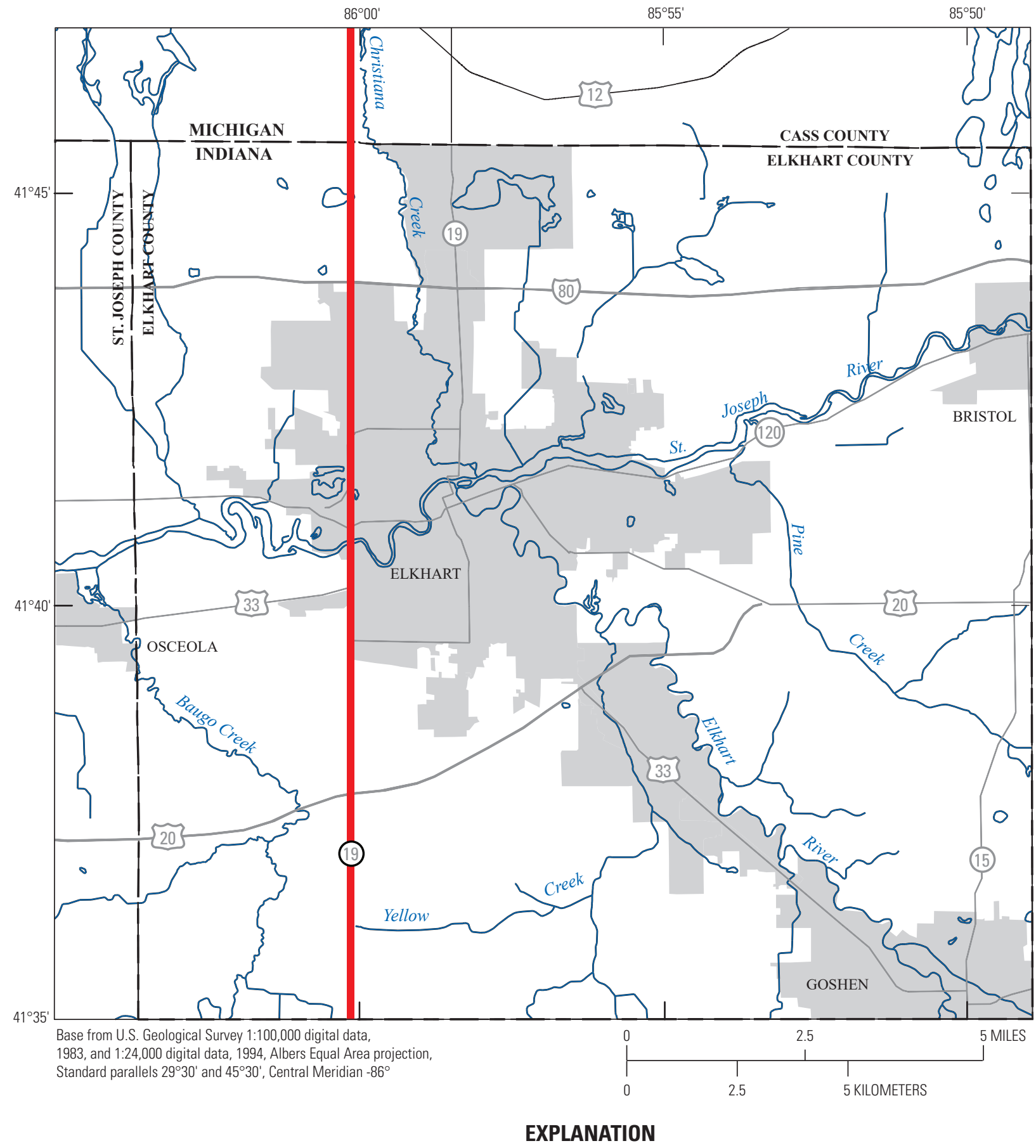

Incorporated urban and developed areas

Location of column 29 of the groundwater-flow model

Figure 21. Location of the cross section along column 29 of the model grid. 


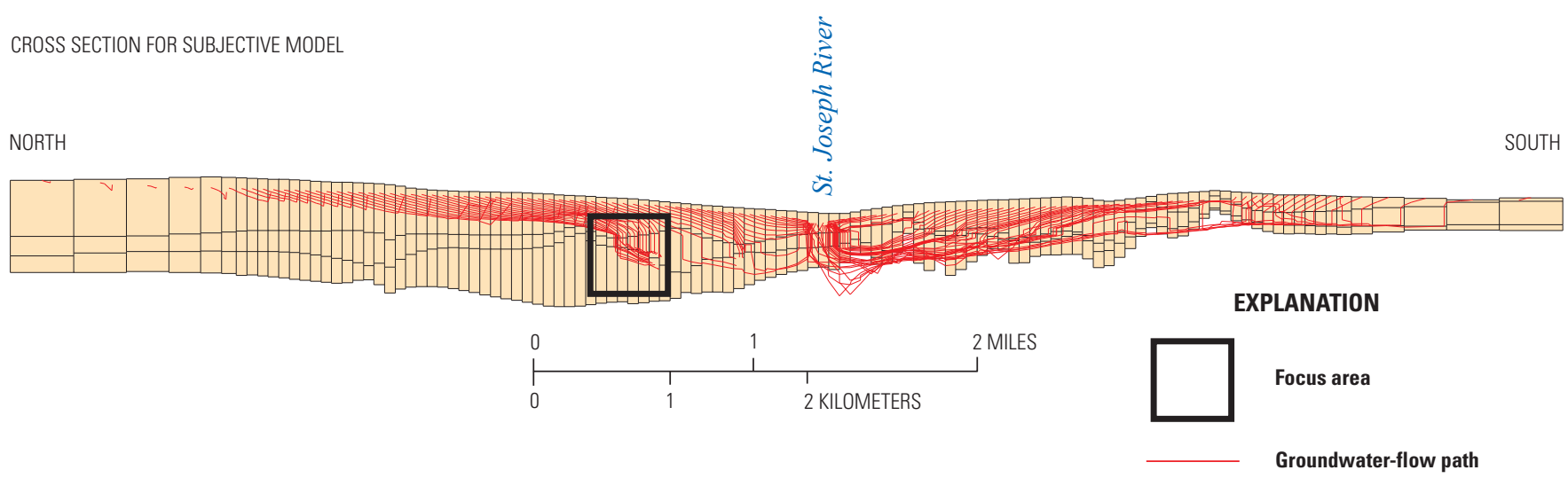

CROSS SECTION FOR OBJECTIVE MODEL

NORTH

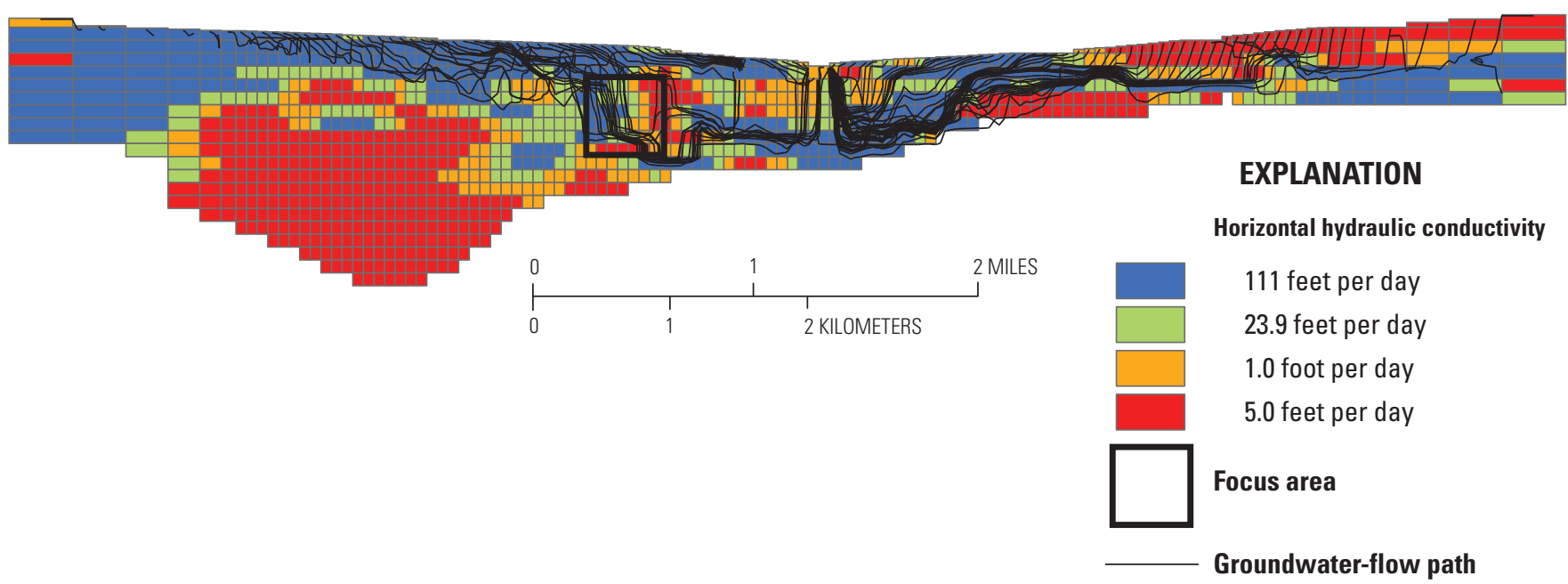

Figure 22. Cross-sectional flow diagram along column 29 for the subjective model and the objective model.

actual drawdowns. The objective model is not as limited in geologic detail as the subjective model because all available well records were used to construct the objective model. Therefore, the confining units in the objective model do not need to be further refined as is the case for the subjective model. Calibration statistics and groundwater-flow path representations are somewhat better in the objective model, but these factors do not necessarily indicate that the objective model more correctly simulates the groundwater-flow system. Additional field data, such as age-date samples to confirm the more complex flow paths simulated by the objective model and a calibration dataset with water-level and water-use information from the same period, would be beneficial to confirm which model simulation is more accurate. Future application of three-dimensional kriging of permeabilities derived from well log lithologies in groundwater-flow simulations would help refine the scientific understanding of the value contributed from the objective model construction approach to simulation outcomes.

The use of constant head outer boundary conditions in subjective and objective simulations was considered to be appropriate for these simulations. The calibrations of the subjective and objective models in this report included comparisons to measured fluxes of groundwater to streams within the model that provided constraint on the overall fluxes through a model, including fluxes through constant-head boundaries at the edge of the models. That constraint, combined with the absence of major stresses near the constant head outer boundaries in each simulation indicates that the use of constant head outer boundaries for the subjective and objective simulations did not artificially influence groundwater flow paths and rates. 


\section{Summary and Conclusions}

Automated data-processing methods allow hydrologists to efficiently incorporate large digital well-record datasets into the construction of hydrostratigraphic frameworks for groundwater-flow models. The method selected to construct the hydrostratigraphic framework can affect the extent of geologic heterogeneity that can be included in the model. The directions of flow, interactions of groundwater and surface water, and the lengths of groundwater-flow paths predicted by groundwater simulations can be, in turn, affected by the detail of modeled hydrostratigraphy. The effects of detail and methodology in modeled hydrostratigraphy on model accuracy, groundwater flow, and groundwater-flow paths are described in this study.

Two methods were used to create groundwater models of glacial deposits in Elkhart County, Indiana. One method, referred to as the subjective method, manually identified stratigraphic boundaries using a subset of well logs from State databases and used two-dimensional kriging to create two aquifer model layers separated by a mostly continuous confining unit of variable thickness. The second method, referred to as the objective method, used three-dimensional kriging to automatically create objective heterogeneous models of the study areas using all available well logs from the State databases. The objective method also increases the potential for geologic contrasts in the vertical dimension by greatly increasing the number of groundwater model layers. An existing model represents the product of the subjective method and a newly calibrated model of the same area represents the objective method.

The statistics measuring model calibration accuracy for the objective model (model constructed by the objective method) of the study area are slightly better than those for the subjective model (model constructed by the subjective method). The mean absolute errors between simulated and measured water levels are 2.04 and 2.16 feet for the objective and subjective models, respectively. Simulated fluxes to measured stream reaches in the objective model were evenly balanced in terms of over and under simulations of measured values; the subjective model tended to overpredict measured fluxes. The overprediction may be related to the 58 percent greater total inflow and outflow through the subjective model. The greater flow rate through the subjective model results from its more continuous and thicker sand and gravel deposits that leads to higher horizontal hydraulic conductivities than was calibrated to in the objective model. Horizontal hydraulic conductivity of aquifer material in the subjective model generally ranged from 170 to 370 feet per day compared to 23.9 to 111 feet per day in the objective model.

The effect of differences in horizontal hydraulic conductivity distributions between the two models for Elkhart County also can be seen in the pattern and age of groundwater-flow paths. The more heterogeneous distribution of horizontal hydraulic conductivity in the objective model is reflected in more-channelized and less-smooth aerial flow paths. At a withdrawal well location, the flow lines for the objective model indicate a wider contributing area than that for the subjective model. The greater contributing area reflects the lower horizontal hydraulic conductivity used in the objective model. Also, the apparent ages of groundwater along flow paths from recharge to discharge points for the objective model are about three times older than ages for the subjective model. Knowing actual flow paths is important to understanding the future distributions of contaminants and the source of water to a well or stream.

The results of simulations from the subjective and objective models for the Elkhart study area indicated a possible improvement associated with the objective model in representing groundwater flow. The results of parameter estimation indicate only two horizontal hydraulic conductivities of (1) sand and (2) combined sand and gravel and gravel were identified to be useful in calibration of the objective model. That result indicates that the improvement associated with the detailed objective model in representing groundwater levels did not result from increased detail in coarse-grained horizontal hydraulic conductivity. Some of the improvement may be associated with the calibration technique (parameter estimation), but because a manual calibration of the objective model was not done, that improvement is not known. The improvement associated with the objective model is likely from increased detail in the distribution of fine- and coarsegrained deposits, as was provided by the additional number of well records used in the construction of the objective model. The improvement also could be associated with the difference in methods used to represent the continuity of the confining unit. The subjective method assumed all occurrences of confining unit deposits represented the same formation; as a result, indicator kriging generated a nearly continuous confining unit. The three-dimensional kriging process used in the objective method did not assume that individual occurrences of fine-grained deposits were of the same formation. Instead, probability of connectivity between two occurrences of fine-grained deposits was always calculated, and commonly the calculation would indicate the two fine-grained deposits were not connected. The resulting discontinuous confining unit predicted by the objective method provided the opportunity for groundwater flow to split over a confining unit into an upper and lower path. The split in flow simulated by the objective model at one location was documented by bromide data; the subjective model did not duplicate the split in flow. Future application of three-dimensional kriging of permeabilities derived from well log lithologies in groundwater-flow simulations would help refine the scientific understanding of the value contributed from the objective model construction approach to simulation outcomes. 


\section{References}

Anderson, M.P., 1989, Hydrogeologic facies models to delineate large-scale spatial trends in glacial and glaciofluvial sediments: Geological Society of America Bulletin, v. 101, no. 4 , p. 501-511.

Arihood, L.D., 2019, MODFLOW-2000 model used to illustrate the differences in flow paths and travel times when three-dimensional kriging is used to estimate the hydraulic conductivity distribution as compared to manual determinations of hydraulic conductivity distribution: U.S. Geological Survey data release, https://doi.org/10.5066/F7QN65RW.

Arihood, L.D., and Cohen, D.A., 1998, Geohydrology and simulated ground-water flow in northwestern Elkhart County, Indiana: U.S. Geological Survey Water-Resources Investigations Report 97-4204, 47 p.

Carle, S.F., and Fogg, G.E., 1996, Transition probability-based indicator geostatistics: Mathematical Geology, v. 28, no. 4, p. $453-476$.

Cooley, R.L., and Naff, R.L., 1990, Regression modeling of groundwater flow: U.S. Geological Survey Techniques of Water-Resources Investigations, book 3, chap. B4, 232 p.

Cross, Bradley, Rogoff, Eric, and Fricke, Levine, 2005, Data visualization tools for litigation-Practical uses and ethical considerations, in Proceedings of the 2005 National Ground Water Association Ground Water and Environmental Law Conference, Baltimore, Md., July 21-22, 2005: Baltimore, Md., National Ground Water Association, 14 p.

C Tech Development Corporation, 2008, Earth science software tutorials and documentation, v. 7.0: accessed January 29, 2008, at http://www.ctech.com/index.php?page.

Dennehy, K.F., 2005, Ground-Water Resources Program: U.S. Geologic Survey Fact Sheet 2005-3097, 4 p.

Desbarats, A.J., 1990, Macrodispersion in sand-shale sequences: Water Resources Research, v. 26, no. 1, p. 153 163.

Desbarats, A.J., and Bachu, S., 1994, Geostatistical analysis of aquifer heterogeneity from the core scale to the basin scale-A case study: Water Resources Research, v. 30, no. 3, p. 673-684.

Duwelius, R.F., and Silcox, C.A., 1991, Ground-water levels, flow, and quality in northwestern Elkhart County, Indiana, 1980-89: U.S. Geological Survey Water-Resources Investigations Report 91-4053, 66 p.

Duwelius, R.F., and Watson, L.R., 1992, Ground-water levels and directions of flow in the vicinity of a well field, Elkhart, Indiana, December 1989: U.S. Geological Survey Open-File Report 92-55, 24 p.
Environmental Systems Research Institute, 2003, ArcInfo, version 8.3: Redlands, Calif.

Fetter, C.W., 1994, Applied hydrogeology: Upper Saddle River, New Jersey, Prentice Hall, 691 p.

Field, A.A., 1991, Application of a three-dimensional ground water flow model and particle tracking for well field management: Dayton, Ohio, Wright State University, M.S. thesis, $149 \mathrm{p}$.

Fleming, A.H., Bonneau, Phillip, Brown, S.E., Grove, Glen, Harper, Denver, Herring, William, Lewis, E.S., Moeller, A.J., Powell, Richard, Reehling, Peter, Rupp, R.F., and Steen, W.J., 1995, Atlas of hydrogeologic terrains and settings of Indiana: Indiana Geological Survey Open-File Report 95-7, 434 p.

Fogg, G.E., 1986, Groundwater flow and sand body interconnectedness in a thick, multiple-aquifer system: Water Resources Research, v. 22, no. 5, p. 679-694.

Fogg, G.E., Noyes, C.D., and Carle, S.F., 1998, Geologically based model of heterogeneous hydraulic conductivity in an alluvial setting: Hydrogeology Journal, v. 6, no, 1, p. 131143.

Freeze, R.A., and Cherry, J.A., 1979, Groundwater: PrenticeHall, New Jersey, 604 p.

Grannemann, N.G., Hunt, R.J., Nicholas, J.R., Reilly, T.E., and Winter, T.C., 2000, The importance of ground water in the Great Lakes Region: U.S. Geological Survey WaterResources Investigations Report 00-4008, 14 p.

Gray, H.H., 1983, Map of Indiana showing thickness of unconsolidated deposits: Indiana Geological Survey Miscellaneous Map 37.

Harbaugh, A.W., and McDonald, M.G., 1996, User's documentation for MODFLOW-96, an update to the U.S. Geological Survey modular finite-difference ground-water flow model: U.S. Geological Survey Open-File Report 96-485, $56 \mathrm{p}$.

Harbaugh, A.W., Banta, E.R., Hill, M.C., and McDonald, M.G., 2000, MODFLOW-2000, the U.S. Geological Survey modular ground-water model-Users guide to modularization concepts and the ground-water flow process: U.S. Geological Survey Open-File Report 00-92, 121 p.

Harrar, W.G., Sonnenborg, T.O., and Henriksen, H.J., 2003, Capture zone, travel time, and solute-transport predictions using inverse modeling and different geological models: Hydrogeology Journal, v. 11, no. 5, p. 536-548.

Hill, M.C., 1998, Methods and guidelines for effective model calibration: U.S. Geological Survey Water-Resources Investigations Report 98-4005, 90 p. 
Hill, M.C., Banta, E.R., Harbaugh, A.W., and Anderman, E.R., 2000, MODFLOW-2000, the U.S. Geological Survey modular ground-water model-User guide to the observation, sensitivity, and parameter-estimation process and three post-processing programs: U.S. Geological Survey OpenFile Report 00-184, 209 p.

Imbrigiotta, T.E., and Martin, Angel, Jr., 1981, Hydrologic and chemical evaluation of groundwater resources of northwest Elkhart County, Indiana: U.S. Geological Survey WaterResources Investigations Report 81-53, 149 p.

Indiana Department of Natural Resources, Division of Water, Water Rights and Use Section, Water Well Record Database: accessed February 26, 2019, at https://www.in.gov/ dnr/water/3595.htm.

Indiana Geological Survey, 2009, National Cooperative Geologic Mapping Program: Indiana, Information sheet of the U.S. Geological Survey, National Cooperative Geologic Mapping Program, 2 p., accessed May 25, 2015, at http://ncgmp.usgs.gov/about/STATEMAP/statefs/IN.pdf.

Indiana Geological and Water Survey, 2019, Petroleum Database Management System: Accessed February 26, 2019, at http://igws.indiana.edu/pdms/.

Johnson, G.H., and Keller, S.J., 1972, Geologic map of the $1^{\circ} \times 2^{\circ}$ Fort Wayne quadrangle, Indiana, Michigan, and Ohio showing unconsolidated sediments: Regional Geologic Map 8b, Indiana Geological Survey, Bloomington, scale $1: 250,000$.

Johnson, N.M., and Dreiss, S.J., 1989, Hydrostratigraphic interpretation using indicator geostatistics: Water Resources Research, v. 25, no. 12, p. 2501-2510.

Journel, A.G., and Huijbregts, C.J., 1978, Mining geostatistics: London, Academic Press, 600 p.

Kim, D.S., Chung, C.K., Sun, C.G., and Bang, E.S., 2002, Site assessment and evaluation of spatial earthquake ground motion of Kyeongju: Soil Dynamics and Earthquake Engineering, v. 22, no. 5 , p. 371-387.

Mandle, R.J., and Kontis, A.L., 1992, Simulation of regional ground-water flow in the Cambrian-Ordovician aquifer system in the Northern Midwest, United States - In Regional aquifer-system analysis: U.S. Geological Survey Professional Paper 1405-C, 97 p.

Martin, P.J., and Frind, E.G., 1998, Modeling a complex multi-aquifer system-The Waterloo Moraine: Groundwater, v. 36, no. 4, p. 679-690.

Mathey, S.B., ed., 1989, National water information system user's manual volume 2, chapter 4-Ground-Water Site Inventory system: U.S. Geological Survey Open-File Report 89-587, 294 p.
Matzke, B.D., Wilson, J.E., Nuffer, L.L., Dowson, S.T., Hathaway, J.E., Hassig, N.L., Sego, L.H., Murray, C.J., Pulsipher, B.A., Roberts, B., and McKenna, S., 2010, Visual Sample Plan Version 6.0 User's Guide(PDF). PNNL-19915, Pacific Northwest National Laboratory, Richland, Washington, 255 p., accessed April 22, 2019, at https://vsp.pnnl.gov/ docs/PNNL\%2019915.pdf.

Michigan Department of Environmental Quality, 2017, WELLOGIC-Electronic Well Record Submittal: Lansing, Mich., Michigan Department of Environmental Quality Fact Sheet, accessed February 26, 2019, at https://www.michigan.gov/documents/deq/deq-wd-gwswcu-wellogicbrochure_270626_7.pdf.

Nastev, Miroslav, Savard, M.M., Lapcevic, Pat, Lefebvre, Rene, and Martel, Richard, 2004, Hydraulic properties and scale effects investigation in regional rock aquifers, southwestern Quebec, Canada: Hydrogeology Journal, v. 12, no. 3, p. 257-269.

Pollock, D.W., 1994, User's guide for MODPATH/MODPATH-PLOT, Version 3; a particle tracking post-processing package for MODFLOW, the U.S. Geological Survey finite-difference ground-water flow model: U.S. Geological Survey Open-File Report 94-464, 231 p.

Proce, C.J., Ritzi, R.W., Dominic, D.F., and Dai, Zhenxue, 2004, Modeling multiscale heterogeneity and aquifer interconnectivity: Ground Water, v. 42, no. 5, p. 658-670.

Reussow, J.P., and Rohne, P.B., Jr., 1975, Water resources of the St. Joseph River Basin in Indiana: U.S. Geological Survey Hydrologic Investigations Atlas HA-537, 3 pls.

Ritzi, R.W., Jr., and Dominic, D.F., 1993, Evaluating uncertainty in modeling flow and transport in heterogeneous buried-valley aquifers, in Conference of Ground Water Modeling, Golden, Colo., June 9-11, 1993, Proceedings: Golden Colo., International Ground Water Modeling Center, Colorado School of Mines, $12 \mathrm{p}$.

Ritzi, R.W. Jr., Dominic, D.F., Brown, N.R., Kausch, K.W., McAlenney, P.J., and Basial, M.J., 1995, Hydrofacies distribution and correlation in the Miami Valley aquifer system: Water Resources Research, v. 31, no. 12, p. 3271-3281.

Ritzi, R.W., Jr., Dominic, D.F., Slesers, A.J., Greer, C.B., Reboulet, E.C., Telford, J.A., Masters, R.W., Klohe, C.A., Bogle, J.L., and Means, B.P., 2000, Comparing statistical models of physical heterogeneity in buried-valley aquifers: Water Resources Research, v. 36, no. 11, p. 3179-3192.

Ritzi, R.W., Jr., Jayne, D.F., Zahradnik, A.J., Jr., Field, A.A., and Fogg, G.E., 1994, Geostatistical modeling of heterogeneity in glaciofluvial, buried-valley aquifers: Ground Water, v. 32 , no. 4 , p. 666-674. 
Russell, I.C., and Leverett, Frank, 1908, Geologic atlas of the United States, Ann Arbor folio, Michigan volume 155Description of the Ann Arbor quadrangle: U.S. Geological Survey Geologic Folio Series, 15 p., accessed February 26, 2019, at https://pubs.er.usgs.gov/publication/gf155.

Schneider, A.F., and Keller, S.J., 1970, Geologic map of the $1 \times 2$ Chicago quadrangle, Indiana, Illinois, and Michigan showing unconsolidated deposits: Regional Geologic Map 4b, Indiana Geological Survey, Bloomington, scale 1:250,000.

Stone, B.D., ed., 2001, Surficial geologic map of Berrien County, Michigan: U.S. Geological Survey Open-File Report 01-156, 1 sheet, scale 1:100,000, accessed May 31, 2019, at https://pubs.usgs.gov/of/2001/ofr-01-0156/ ofr-01-0156.pdf.

U.S. Geological Survey, 1998, Strategic directions for the U.S. Geological Survey Ground-Water Resources Program: A Report to Congress, November 30, 1998, 14 p., accessed July 19, 2017, at https://water.usgs.gov/ogw/gwrp/stratdir/ stratdir.pdf.
Weissmann, G.S., and Fogg, G.E., 1999, Multi-scale alluvial fan heterogeneity modeled with transition probability geostatistics in a sequence stratigraphic framework: Journal of Hydrology, v. 226, nos. 1-2, p. 48-65.

Weissmann, G.S., Zhang, Yong, LaBolle, E.M., and Fogg, G.E., 2002, Dispersion of groundwater age in an alluvial aquifer system: Water Resources Research, v. 38, no. 10, $13 \mathrm{p}$.

Zhang, Zhihui, and Brusseau, M.L., 1998, Characterizing three dimensional hydraulic conductivity distributions using qualitative and quantitative geologic borehole data-Application to a field site: Ground Water, v. 36, no. 4, p. 671-678. 
For additional information concerning this publication, contact:

Director, Ohio-Kentucky-Indiana Water Science Center

U.S. Geological Survey

5957 Lakeside Boulevard

Indianapolis, IN 46278-1996

(317) 290-3333

Or visit the Ohio-Kentucky-Indiana Water Science Center website at: https://www.usgs.gov/centers/oki-water

Publishing support provided by the Madison, Rolla, and Pembroke Publishing Service Centers 
